\title{
Alluring freedoms: Heideggerian possibilities for an ethical encounter with dying and death
}

\author{
By
}

Julia Brotea

A thesis submitted to the Faculty of Graduate and Postdoctoral Affairs in partial fulfillment of the requirements for the degree of

\author{
Doctor of Philosophy \\ In \\ Political Science \\ Carleton University \\ Ottawa, Ontario
}

(C) 2011

Julia Brotea 
Library and Archives

Canada

Published Heritage Branch

395 Wellington Street

Ottawa ON K1A ON4

Canada
Bibliothèque et

Archives Canada

Direction du

Patrimoine de l'édition

395 , rue Wellington

Ottawa ON K1A ON4

Canada
Your file Votre référence

ISBN: 978-0-494-83239-4

Our file Notre référence

ISBN: 978-0-494-83239-4
NOTICE:

The author has granted a nonexclusive license allowing Library and Archives Canada to reproduce, publish, archive, preserve, conserve, communicate to the public by telecommunication or on the Internet, loan, distribute and sell theses worldwide, for commercial or noncommercial purposes, in microform, paper, electronic and/or any other formats.

The author retains copyright ownership and moral rights in this thesis. Neither the thesis nor substantial extracts from it may be printed or otherwise reproduced without the author's permission.
AVIS:

L'auteur a accordé une licence non exclusive permettant à la Bibliothèque et Archives Canada de reproduire, publier, archiver, sauvegarder, conserver, transmettre au public par télécommunication ou par l'Internet, prêter, distribuer et vendre des thèses partout dans le monde, à des fins commerciales ou autres, sur support microforme, papier, électronique et/ou autres formats.

L'auteur conserve la propriété du droit d'auteur et des droits moraux qui protège cette thèse. $\mathrm{Ni}$ la thèse ni des extraits substantiels de celle-ci ne doivent être imprimés ou autrement reproduits sans son autorisation.
In compliance with the Canadian Privacy Act some supporting forms may have been removed from this thesis.

While these forms may be included in the document page count, their removal does not represent any loss of content from the thesis.
Conformément à la loi canadienne sur la protection de la vie privée, quelques formulaires secondaires ont été enlevés de cette thèse.

Bien que ces formulaires aient inclus dans la pagination, il n'y aura aucun contenu manquant. 


\section{Abstract}

In this study, I evaluate Jacques Derrida's claim that Martin Heidegger may provide us with a more appropriate language in which to discuss dying and death in our time. I begin each chapter by examining one of five end of life issues. These issues are the right to die, suicide, euthanasia, life support, and immortality. I draw from the work of bioethicists and, where appropriate, from the work of scientists working in the biotechnological and medical sciences. Occasionally, I also rely on historical accounts to trace changes in perceptions and practices related to some of these issues. Yet, the main method for this study is an exegesis of Heidegger's work.

In the end, I argue that end of life issues can be used to reveal multifarious conceptualizations of freedom present in Heidegger's thought. These Heideggerian conceptualizations of freedom are dangerous either to elements of negative freedom, present in liberal thought, or to politics in general. If Heidegger's thoughts are indeed being used to enrich our modern ethical views about dying and death, then they are necessarily being used out of context and contrary to what Heidegger had actually intended them to mean. If, however, his concepts were to be taken integrally, respecting the larger context in which he conceived them, then they would prove corrosive to liberal democratic principles that modern medical ethics still strives to follow. 


\section{Acknowledgements}

Writing this dissertation on end of life issues has been a difficult, but tremendously rewarding, experience. Throughout this process, I was fortunate to be surrounded by people I could count on for support and encouragement.

Among them, I am particularly grateful to have received guidance from my supervisor and kind mentor Professor Tom Darby. His willingness to share his powerful insight over the years, and his commitment to helping me along the way, made this experience less solitary and profoundly enriching. Professor Darby has taught me how to 'speak' about technology and about Heidegger's philosophy. In doing so, he helped me lay the foundation for this work.

I wish to also thank Professor Peter Emberley for committing his time and effort to helping me understand the writings of St. Augustine. I found our discussions to be some of the most thoughtful and compelling I have ever had.

I am also grateful for my family's loving support and encouragement. To my husband, François Nadeau, for his clam and loving help as well as his careful editing and re-editing of this work in an effort to give it clarity. To my stepfather, Robert Sainsbury, for always providing me with the right perspective on things and for his comments and insight on my work. To my mother Despina Brotea, for being a powerful role-model and protective presence in my life. Most of all she taught me that I must always 'return to the world.' My thanks to my father Adrian Brotea, for showing me the beauty and the danger of disinterested learning often 'too far from the world.' And, special thanks to Pamela Huber, her friendship sheltered me from taking my readings too seriously. 
I am also indebted to the Canadian taxpayers, who, through Social Science and Humanities Research Grants and Ontario Graduate Scholarships, helped fund my doctoral work.

Finally, this work is dedicated to my dear son Galen Nadeau, who is teaching me about the beauty of beginnings. 


\title{
Table of Contents
}

\author{
Acceptance form ii
}

Abstract iii

Acknowledgements iv

Table of Contents vi

\section{Introduction 1}

Cultural attitudes towards dying and death 4

The political challenges of biotechnology 6

Heidegger's discourse on de bene moriendi 11

Heidegger's conceptualizations of freedom 14

Breakdown of this work 20

Chapter 1. The fascination with freedom in the right to die 27

The right to die in brief context 28

Schopenhauer and the right to die 35

Metaphors of creation about the right to die 43

Freitod and deceptive freedom 53

Concluding remarks 57

\section{Chapter 2. Suicide and Being-towards-Death 60}

Categories of suicide 61

Brief history of suicide 67

Rationalizing suicide 70

The Meaning of Dasein 76

Dasein and Being-towards-death 79

The impossibility of suicide: Thrown in the world 85

Concluding remarks 89

Chapter 3. Euthanasia and judging 'the good death' 91

Historical overview of the 'good death' 92

The Christian death 93

The romanticizing of death 100 
The institutionalization of tuberculosis 105

Euthanasia in Nazi Germany 109

Modern euthanasia 113

'The others' and 'the they' - empathy in Heidegger's thought 121

Historical resoluteness 132

The danger of 'the they' deciding 'the good death' 136

Concluding remarks 138

\section{Chapter 4. Life support and technological thought 141}

Overview of life support in the Intensive Care Unit (ICU) 143

Making decisions in the ICU 147

Ancient drama in scientific thought 154

The scientific method and the meaning of facts 158

Modern medicine and technological thought 162

The possibility for politics 167

Concluding remarks 170

Chapter 5. Physical immortality and the control of time $\mathbf{1 7 2}$

Immortal beings of an endangered species 175

Is immortality a good in itself? 181

Time as presence 187

Resolute time and Christian Influences 190

Dasein's resoluteness: a future to be mastered 194

Immortals without time 200

Concluding remarks 203

\section{Conclusion 206}

Bibliography 213 


\section{Introduction}

Dying and death are not subjects that can be fully understood, nor can one desire to become an expert in these matters. Quite the contrary; human beings desire to know nothing of either dying or death and they hope to evade them both. Despite this, the subject is a resilient one, and it is also becoming a morally difficult and a politically contentious one. Aside from the inevitable confrontation with the dying and death of a loved one, advancements in medical technology also invite decisions in matters previously reserved for contemplation and final surrender to death. Thus, the threshold between life and death that is reserved for each one of us is now increasingly populated by machines, medical professionals, family members, and social workers that engage in political, moral, and scientific debates over dying and death, and that increasingly decide whether to accelerate or delay our final transition from life to death.

These decisions are among the most formidable ones our generation has to make in the developed world and, in many cases, they lack a historical precedent. It is indeed historically unprecedented that the practice of children deciding to remove a parent from life support is becoming routine in our society. Not surprisingly, most parents want to shelter their children from this difficult choice and some opt for taking their own life instead or pressure their doctor to do so for them. Many doctors find this to be an affront to their commitment to saving lives and thus refuse the dying men and women their wishes.

We would often prefer not making these choices, and we are sometimes willing to allow others to make them for us instead. This avoidance of 
responsibility, however, can lead to the greater danger of forfeiting the freedom to decide for ourselves matters that are most important to us. The circumstances under which these decisions are made, and the motives behind some of them, reflect the dark side of technological progress in the medical sciences. Yet, it is a dark side we must reckon with nevertheless.

The increasingly secular and culturally diverse society in which we live further complicates these decisions, and the circumstances surrounding them. Even leaving aside Michel Foucault's socio-historical explanation of biopower and the dangers of ubiquitous oppression he argues this power unleashes, there is still an easily identifiable fascination with health and medicine that is more prevalent in secular societies. Previously, medicine derived its moral codes from dominant religious and cultural views. Asclepius, the first physician, was even struck down by Zeus for his disobedience as the legend has it. Christian Medieval Europe generated medical practices typified by the duty to care for the poor and the sick. The consolidation of the political principle of la nobles oblige manifested itself in the medical ethics as a sense of obligation on the part of physicians to cure their patients. The replacement of duty with rights, made famous by John Locke, also a physician by trade, generated a medical ethics whereby physicians entered into a contract with their patients. ${ }^{1}$

However, the last few decades bear testimony to a reversal of this trend, as health care debates have become themselves an important source from which we derive broader moral and ethical values in society. As Margaret Somerville argues, health care debates became "a forum of creating values, implementing

\footnotetext{
${ }^{1}$ Albert R. Jonsen, The New Medicine and the Old Ethics (Cambridge: Harvard University Press, 1990).
} 
those values and carrying them forward" and consequently, in more secular societies such as Canada, healthcare have become an ethics laboratory. ${ }^{2}$ The findings that emerge from this 'laboratory' experiment carry a great weight, since the manner in which the dying are cared for and the dead are respected and remembered defines the kind of people we are and the world in which we live.

Though it is indeed difficult to foresee in detail what kind of world changes in perceptions and practices about dying and death will bring about, it is nevertheless possible to observe certain patterns of change and point to certain dangerous implications these changes may represent in the future. To understand some of those changes, this work will focus on dying and death in the context of modern biotechnology. This is an area where medicine is intertwined with philosophy and where technological certitude is riddled with abstract ambiguity. Thus, to create a more comprehensive description of the issues discussed, I will introduce them, together with the questions they raise by drawing primarily from literature in the actual discipline of bioethics. Since this work is intra-disciplinary, it will also attempt to explain some of the implications that result from changes in dying and death and the moral quandaries they unleash from the perspective of political philosophy.

Specifically, it engages potential insights and possible dangers present in Martin Heidegger's thought for bioethics in the context of dying and death. I focus on Heidegger's thought because I am intrigued by Jacques Derrida's claim that Heidegger can provide us with the best discourse on dying and death. I therefore decided to test if this is indeed the case. By pursuing this challenge, I

\footnotetext{
${ }^{2}$ Margaret Somerville, The Ethical Canary: Science, Society and the Human Spirit (Toronto: Viking/Penguin Canada, 2000), 1, 4.
} 
show that end of life issues such as the right to die, suicide, euthanasia, life support technology, and immortality can be used to reveal various conceptualizations of freedom in Heidegger's thought. These freedoms are at once appealing and dangerous to modern liberal societies. End of life issues also provide a powerful way to evaluate Heidegger's discourse on dying and death, because the existential engagement he proposes is meant to be most suitable for engaging real life experiences.

\section{Cultural attitudes towards dying and death}

In colloquial terms, as well as in the literature of bioethics, the words dying and death are often reversed when they are mentioned together. However, the more accurate order is the one employed here not only because it represents the actual chronology, as Northcott and Wilson remarked but because advancements in biomedical technology have prolonged the dying process in the developed world. This prolonged dying process is in turn responsible for most of the controversies surrounding end of life issues. Indeed, if people did not experience a prolonged dying period, it is probable that perceptions about dying would not be as strongly questioned as they currently are in the developed world. The reverse phrase 'death and dying' thus represents, from the perspective of medically advanced societies, an atavism from a historical period when dying could not be prolonged for long. The fact that modern biomedical technology makes it possible to watch a loved one die for years causes one to question the manner in which we should confront dying and the degree to which we should intervene to alleviate the suffering of a human being. 
Furthermore, the manner in which dying and death occur is also indicative of the society in which we live. Typically, dying occurs early in life in societies that experience poverty, inadequate nutrition, and sanitation, war and civil unrest, and a shortage of medical technology. By contrast, dying and death commonly occur late in life in the developed world where people benefit from relative peace, wealth, and modern medical technology. ${ }^{3}$ Yet, despite these benefits, people in the developed world also experience a lengthier dying period and face a society that is ambivalent, and even in denial about the inevitability of death.

Ours is also a society in which science and technology play an increasingly prevalent role in how people think about end of life issues. The biological understanding of death as an end to life's basic functions is increasingly more relied upon especially since technology such as the EEG can now be used to diagnose one's death. These various machines may accurately test the absence of bodily functions, but they cannot provide a standard for judging life beyond these mere functions. In other words, neither science nor technology can grant meaning to death beyond our understanding of death as an end of biological functions. Moreover, neither is capable of illuminating man's consciousness of his own death.

To further complicate matters, this consciousness is riddled with ambiguity in our culture. Norbert Wiener's insights from the 1950s continue to be relevant to our world. He argues that "the education of the average American child of the upper middle class is such as to guard him solicitously against the

\footnotetext{
${ }^{3}$ Herbret C. Northcott and Donna M. Wilson, Dying and Death in Canada, second edition (Peterborough: Broadview Press, 2008), 14.
} 
awareness of death and doom." ${ }^{\prime 4}$ The danger Wiener sees with this sheltering consists in the individual's refusal to acknowledge death and his struggle "to build up a Heaven on Earth in which unpleasantness has no place." ${ }^{5}$ Dostoevsky presented a similar argument in The Brothers Karamazov through the Grand Inquisitor, who also took away men's anxieties about their deaths: "And everyone will be happy....They will die peacefully with Your name on their lips but beyond the grave they will find nothing but death." ${ }^{16}$ Aldus Huxley, in the popular novel Brave New World, also draws awareness to the danger of opting for a pre-programmed society to evade the suffering associated with dying and death. These accounts, point to some of the moral and political costs of evading the painful and difficult, though inherently human, process of dying and death.

\section{The political challenges of biotechnology}

Adding to the difficulty of confronting the inevitable is the increasingly prevalent role that biotechnology has in mediating the threshold between life and death. Biotechnology is an extreme version of technology that centers on human life and medicine. The effect of biotechnology on human beings is manifest on a continuum that includes all aspects of life from birth, to growth, and until death. Hence, biotechnology includes reproductive technologies such as in-vitro fertilization and fertility enhancements. It also includes life

\footnotetext{
${ }^{4}$ Norbert Wiener, The Human Use of Human Beings: Cybernetics and Society, trans. Talcott Pearson (Boston: Houghton Mifflin, 1954), 41.

${ }^{5}$ Ibid.

${ }^{6}$ Fyodor Dostoyevsky, The Brothers Karamazov, trans. Andrew H. MacAndrew (New York: Bantam Books), 313.
} 
maintenance procedures, such as annual medical exams, or major surgeries involving, but not limited, to organ transplants. And finally, biotechnology includes life prolongation technologies such as life support technologies, and life ending technologies such as lethal drugs and the infamous Kevorkian machine. In short, biotechnology is omnipresent in the developed world and is often taken for granted. If questioned at all, it is questioned mostly in critical situations. Indeed, few of us would question the benefits of an annual medical exam; though most of us do wonder whether we would want life support intervention to sustain our lives. This work engages the presence of biotechnology in its extreme form, at the threshold between life and death, and begins by examining the manner in which advancements in biotechnology make dying, and the occurrence of death, contentious issues.

Advancements in biotechnology have generated an environment in which I can ask the question 'When is one dead?' without being able to receive a clear answer. Though, as Engelhardt pointed in dark humor, after a while, even nonexperts can establish death based on their olfactory sense. However, establishing the exact time of death, and even confirming one's death, have become difficult undertakings. For example, legal-death used to refer to heart failure. Yet hearttransplants now bring people 'back to life' after their natural hearts have stopped beating. ${ }^{7}$ This legal definition was also shown to be ridiculous in the Grey et al vs. Sawyers et al case in Kentucky. In this legal dispute, even though both husband and wife died together in an unfortunate car accident, it was important to establish who died first due to inheritance disputes. The case concluded that

\footnotetext{
${ }^{7}$ Tristram Engelhardt, The Foundations of Bioethics (New York: Oxford University Press, 1986), 245.
} 
the wife outlived her husband in a decapitated state because her heart continued to spurt blood through the neck after her husband had died. ${ }^{8}$ More recently, heart failure also became an unreliable indicator of death, especially as ventricular assistance devices (VAD) now exist and can partially or completely replace the role of a heart. If a person has a VAD installed, he has no pulse, but he is still technically alive. Thus, while it used to be accurate to call someone dead upon his last breath, modern medicine has rendered this definition inaccurate because technology can now bring people 'back to life.'

Current reliance on brain-death diagnosis is also riddled with controversy due to the lack of consensus about which part of an individual's brain must be dead to qualify that individual as dead. It must also be stated that to date, nobody has been brought back to 'life' after being entirely 'brain dead,' a diagnosis for which only one exam is needed now ${ }^{9}$ and occasionally an interpretation of an electroencephalography (EEG). Yet, some people have been kept alive by being attached to mechanical ventilations that sustain breathing. This diagnosis is problematic, however, because people can be kept barely alive on life support, while declared legally dead, and have their organs harvested. ${ }^{10}$

Moreover, the current ability to grow brain cells through stem cell stimulation makes the re-growth of the central nervous system possible. The question this discovery raises is not whether this person would be dead or not (they would clearly be alive), but whether it would be the same person. Hence, it

${ }^{8}$ Engelhardt, The Foundations of Bioethics, 246.

9 Alisson Gandey, "New Brain Death Guidelines Issued," Medscape Medical News, June 10, 2010. Accessed on February $15^{\text {th }} 2011$.

http://www.medscape.com/viewarticle/723342

${ }^{10}$ Koppelman, E. R. 2003. "The dead donor rule and the concept of death: Severing the ties that bind them." The American Journal of Bioethics 3(1): 1-9. 
is reasonable to assume that the current definition of brain-dead will be obsolete just like the saying 'breathing his last breath' and heart failure have become.

This brings the debate to the difficult question of whether human beings have an inherent holistic essence, or are they just made up of 'replaceable' parts, ${ }_{11}^{11}$ or even whether these parts can be as small as amino acids forming the DNA. If humans are to be conceptualized as being comprised solely of parts, and brain-death and heart failure diagnoses of death fit this understanding, then they may be able, aided and abided by biotechnology, to fend off death for longer periods. They can do so by replacing organs and body parts that become 'defective.'

Arguments against the use of biotechnology for the prolongation of life range from religious to scientific in nature. Theologians argue that this approach to human life risks undermining the sanctity of human life by considering a human being to be merely the sum of its body parts and thereby neglecting its soul. Scientists on the other hand, argue that perpetual prolongation of life would stagnate the evolutionary process, thereby eliminating biological variation and compromising human beings' ability to adapt to future changes in the environment.

Beyond these arguments, there is also the darker issue of extending life without it being youthful. As such, to the exiting debates are added the more complex ones as some people refuse the use of technology that could help them live longer, and opt instead for ways to die sooner. I am referring here to decisions to end life support, death with dignity clinics, physicians practicing

\footnotetext{
${ }^{11}$ Ludwik Fleck, Genesis and Development of a Scientific Fact, trans. Fred Bradley and Thaddeus J. Trenn (Chicago: University of Chicago Press, 1979).
} 
active and passive euthanasia, as well as suicide. In the case of suicide and euthanasia, for example, aside from the religious arguments against them, the Western legal tradition that upholds both the right to life and the right to liberty has witnessed the use of these rights in conflict with one another. ${ }^{12}$ Imbedded in those legal debates is a highly ambiguous language that upholds certain rights but not others. George Grant's argument against abortion applies to the current discussion. Grant analyzes the use of phrases such as 'quality of life' and concludes that "[o]nce we start grading the right to life in terms of quality, our criteria are seen to exclude more and more groups from human status. What will we be willing to do to these groups?"13 Indeed, the dark consequences that brash judgments on human life can have on our society remain a daunting challenge to reckon with both legally and politically.

Thus, modern end of life issues expose limitations to rights-based approaches and invite a more comprehensive engagement. To state the problem in more dramatic, but accurate, terms advancements in biotechnology place us in the position of deciding politically the answer to the question 'When should one die?' as well as 'When should I die?' The increase in life span that derives from biotechnology brings us to the limit of contemplating a question with even more dramatic ramifications such as 'Why should one die?' This forces us to reckon with immortality on this side of the grave.

${ }^{12} \mathrm{~K}$. Amarasekara and M. Bagaric. “The Vacuousness of Rights in the Euthanasia Debate." The International Journal of Human Rights, Vol. 6:1 (2007): 19-44.

${ }^{13}$ George Grant, Technology and Justice (Concord: House of Anansi Press Ltd., 1986), 127. 


\section{Heidegger's discourse on de bene moriendi}

It is ironic that Jacques Derrida, a thinker committing so much effort to being apolitical, actually launched an invitation for a new way of engaging ethical issues concerning dying and death. In Aporia, Derrida discusses the components that comprise the aporia of death by drawing from Martin Heidegger's Being and Time. Here, he outlines the linguistic ambiguity that surrounds death in our culture (i.e. the differences between perishing and dying or between death and demise, as well as the cultural and natural interplays death implies). In Derrida's words: "Dying is neither entirely natural (biological) nor cultural...[it] is also the question of the border between cultures, languages, countries, nations and religions, as well as that of the limit between the universal (although nonnatural) structure and a differential (non-natural but cultural) structure." ${ }^{14}$ Death is an undeniable limit of man and the attempt to approach it from a purely cultural/anthropological perspective that we encounter, for instance, in the work of Philipe Aries, risks, according to Derrida, conceptualizing the experience of death as entirely relative to particular cultures or historical periods. ${ }^{15}$

Differently from Aries, Derrida remains closer to the existential tradition, but replaces Heidegger's 'authentic being towards death' with 'awaiting death.' As he writes: "A certain thinking of the possible is at the heart of the existential analysis of death. (For Heidegger, moreover, it is never very far from the thinking of the heart.)...Heidegger would certainly not accept making this possibility of impossibility, that is, of dying, or of what I have called the

${ }^{14}$ Jacques Derrida, Aporia (Stanford: Stanford University Press, 1993), 42.

${ }^{15}$ Philippe Aries, Western Attitudes toward Death (Baltimore, Maryland: John Hopkins University Press, 1974). 
'awaiting death.'"'16 The ethical implications are often ambiguous in Derrida's work and Aproia is no exception. Indeed, while he openly admits that, with regards to ethics, "the existential analysis of death has nothing to say on this matter," he does nevertheless leave open the possibility that Heidegger may "ultimately give us a discourse on the best, indeed the most proper and most authentic, relation to dying: hence de bene moriendi." ${ }^{17}$ Thus, Derrida maintains that, while it may be difficult to employ Heidegger's thought directly to policymaking, or even use it to make recommendations on issues of dying and death, Heidegger's work can nevertheless provide a valuable language for articulating and conceptualizing some of these issues.

Derrida's belief that Heidegger may provide us with the best discourse for dying and death, or of de bene moriendi, in some ways sparked my interest in pursuing this topic. The underlining questions that guide this work can be summed up as: Is Heidegger's discourse fitting for engaging the current controversial issues that surround dying and death? I am referring here to debates over the legal proposals for creating a 'right to die,' suicide, euthanasia, life support technology and immortality. The other question is: Given Heidegger's critical views about liberal thought, can his insights be incorporated in the liberal democratic framework, or would they actually prove corrosive to our liberal tradition of rights and freedoms? In sum, it my intention to examine the implications of Heidegger's thought and discourse for the current debates on dying and death in the modern context.

\footnotetext{
${ }^{16}$ Derrida, Aporia, 62, 72.

${ }^{17}$ Ibid., 60.
} 
A possible answer to the first question asked above is that it is indeed probable that advancements in biotechnology will support Derrida's prediction that Heidegger will penetrate into the current discourse on death. Traditionally the manner in which one faced death was a preoccupation of philosophers, Socrates being a prime example, and of theologians. Now, advancements in biotechnology make it necessary for the state to extend its jurisdiction over dying and death. Consequently, the search for philosophical resources for dealing with issues such as euthanasia or life support is commonsensical. Furthermore, given the diverse citizenry to which laws must apply, the reliance on religious arguments against euthanasia, or in favor of life support, is unsatisfactory to many secular citizens. Hence, Martin Heidegger's thought, being both modern, and, on the surface at least, devoid of Christian biases, may present an appealing alterative.

To date, in my research, I have not encountered any ethical arguments in the field of bioethics that are explicitly rooted in Heidegger's Being in Time or any of his earlier works. However, I did come across significant references to Heidegger's later work on technology, which is often considered separately from his earlier work. Passing examples include Francis Fukuyama, who writes "The rule of enframing (Gestell) threatens man with the possibility that it could be denied to him to enter into a more original revealing and hence to experience the call of a more primal truth." ${ }^{\prime 18}$ Along the same lines, Leon Kass writes "perhaps most troubling, our views of the meaning of our humanity have been so transformed by the scientific-technological approach to the world and to life that

\footnotetext{
${ }^{18}$ Francis Fukuyama, Our Posthuman Future: Consequences of the biotechnology revolution (New York: Farrar, Straus and Giroux, 2002), 3.
} 
we are in danger of forgetting what we have to lose, humanly speaking." ${ }^{19}$ While the examples of Heideggerian influence in bioethics do not resume with Fukuyama and Kass, they are important figures because they were both members of The President's Council on Bioethics under the George W. Bush administration. In other words, both played an influential role in bioethics, not only as writers, but also as presidential advisors. Thus, in an indirect way, part of Heidegger's discourse is already present in the modern discourse of bioethics; though admittedly not the part that Derrida had in mind. Despite this fact I will argue that the greatest danger posed by Heidegger's work as it relates to conceptualizing end of life issues, lies in alluring references to freedom present throughout his work.

\section{Heidegger's conceptualizations of freedom}

If reason as logos typified Ancient Greek philosophy, and the search for God characterized Christian thought, then freedom, Heidegger would argue, typifies the modern era. Yet, like reason, freedom also existed before men began to discuss it at length in philosophy. In short, philosophical preoccupation with freedom does not entail a transformation in man's nature any more than Socratic reason changed men's nature. Indeed, as Aristophanes points out in his characteristic humor, the men of Athens did not sit and stare idiotically before

${ }^{19}$ Leon R. Kass, Life Liberty and the Defense of Dignity: the Challenge for Bioethics (San Francisco: Encounter Books, 2002), 8. 
Socrates came along to show them reason. ${ }^{20}$ And yet, the conceptualization of reason (logos) did allow Socrates to outline a way for the proper ordering of the soul towards the good. Along similar lines, thinkers such as Friedrich Schelling and Nietzsche did not discover freedom, but rather, Heidegger argues, discovered a new way of using freedom that unleashed "a new beginning" ${ }^{21}$ in the way men related to one another and to nature.

Differently from early thinkers philosophizing about freedom, Heidegger considered himself a thinker of 'endings.' He also regarded the preoccupation with freedom in colloquial talk as an indication that the spark of originality has vanished and he doubted that authentic thinking of freedom was still possible. Consequently, Heidegger's own engagement with freedom is ambivalent. Indeed, Heidegger himself alerts us to some of the dangers lurking behind the understanding of freedom in German Idealism. It is also Heidegger who tries to address some of these problems. However, as I will show in this study, at times, some of the solutions he devises are themselves susceptible to his own criticisms. At other times, he does not follow the logical avenues of addressing dangers in our contemporary world, despite the fact that these avenues are contained in his very work.

In his lecture notes on Schelling and his work on freedom, titled The Essence of Human Freedom, Heidegger engages with different conceptualizations of freedom. He shows that freedom can be metaphysical because it can contain the possibility of a universe free of causality. It can also be political in as far as it

\footnotetext{
${ }^{20}$ Aristophanes, The Frogs, In The Wasps/ The Poet and the Women/ The Frogs (London: Penguin Books, 1964), 192.

${ }^{21}$ Martin Heidegger, Schelling's Treatise on the Essence of Human Freedom, Trans. Joan Stambaugh (Athens, Ohio: Ohio University Press, 1985), 3.
} 
involves action in the here and now. It can be artistic and unleash unbound creations. It can be a thought guided by reason and allowed to wonder and to forget that to wonder is derived from the verb to err. Freedom can also be captured in a moment when one is free to decide. Through this moment, it can claim time itself. And finally, freedom can also be taken away. Once lost, it can, such is its nature, also be regained. Though poetically expressed, the above represent some of the ways Heidegger interprets freedom.

In his lecture notes on Schelling, Heidegger credits Schelling for being one of the first thinkers to 'think' freedom and to devise a 'metaphysics' of freedom. Though it is also important to mention that Schelling's work is itself less systematic than Heidegger makes it out to be, and that, as Ruin points out, Heidegger does interpretative violence to Schelling's understanding of the divine and the role of pantheism. ${ }^{22}$ Here, I do not attempt to correct this and to examine these debates. Instead, I will focus solely on Heidegger's remarks about freedom in this work, not because I judge them to be correct, but because, in the context of this work, they are a good starting point for outlining some of the appealing ways in which Heidegger understands freedom.

Schelling conceptualizes freedom in conflict with necessity and he argues that philosophy represents that constant tension between the two: a tension that could be properly reconciled in a system. Heidegger disagrees that freedom can indeed be reconciled in a system of thought or that it even should be reconciled, and focuses instead on the various ways in which freedom can be understood.

He outlines seven broad categories of freedom, which he argues, typify

\footnotetext{
${ }^{22}$ Hans Ruin, “The Destiny of freedom: in Heidegger," Continental Philosophy Review 41(2008): 277-299.
} 
the modern understanding of freedom and especially German Idealism. These seven categories include: freedom as a self-starting of a series of events, or a being-ablein-terms-of-oneself, or simply phrased, freedom understood as the ability to will. The second and third are positive and negative freedoms, meaning the freedom from something and freedom towards something. The fourth is the freedom from causality. Differently from Kant who argues for a universe characterized by causality, Heidegger claims that causality is itself the product of freedom. The fifth is freedom to self-legislate. Sixth is freedom as the capacity for good and evil, and seventh is freedom as mere indecisiveness or libertas indifferentiae. ${ }^{23}$ These freedoms are appealing in part because they exceed the two basic freedoms from and towards that typify the liberal tradition.

In the same work, as well in his later works, Heidegger also criticizes some of the radical freedoms contained in the German Idealism and attempts to distance himself from this tradition. One of these freedoms is the freedom to selflegislate ${ }^{24}$ or an understanding of freedom as the independence to stand within one's own essential law. ${ }^{25}$ As the first chapter will show, Heidegger attributes this freedom not only to Schelling but especially to Nietzsche. He also develops the implications of this freedom most clearly in his four-volume work on Nietzsche. Heidegger, however, does not claim this freedom in his own work and is even critical of it. His criticism of both Nietzsche and German Idealism pertains to "the mere egoity of the 'I can"'26 which denotes an exaggerated

\footnotetext{
${ }^{23}$ Heidegger, Schelling's Treatise on the Essence of Human Freedom, 88 -102.

${ }^{24}$ According to Leo Strauss this freedom in fact begins with Rousseau. See Natural Right and History (Chicago: University of Chicago Press, 1965), 278, 281.

${ }^{25}$ Heidegger, Schelling's Treatise on the Essence of Human Freedom, 94.

${ }^{26}$ Ibid., 60.
} 
emphasis on the subject as a free-floating "I." In sum, Heidegger criticizes German Idealism for its radical subjectivity.

Heidegger attempts to correct this in two ways: by rooting the individual more firmly in the community and grounding his relations with others in empathy; and by generating Dasein $^{27}$ as a mode of understanding the essence of man. Yet, as the second chapter will show the emphasis on community as 'authentic being with others,' typified by empathy, becomes realizable only if the community adopts a common historical destiny and becomes resolute in struggling towards it. This common destiny, however, if achieved, will be oppressive rather than free because it would be limited to a 'like-minded' people whose ethics are one with their laws.

This problem also is exacerbated by the fact that Heidegger believes the time for authentic and free political interaction has passed. Indeed as the fourth chapter of this work will show, Heidegger would rather rely on artistic freedom, which is not bound to any laws and which does not follow a higher order, than to place his trust in politics.

The notion of Dasein is also meant to counter the radical subjectivism contained in German Idealism. As the second chapter will show, this attempt is even contained in the words that make up Dasein and that can also be translated as Being-here. However, while Dasein is rooted in the world, it is also open towards Being. ${ }^{28}$ This radical openness of Dasein marks also a greater openness

${ }^{27}$ For a more comprehensive engagement with the meaning of Dasein please see Chapter 2.

${ }^{28}$ Being is a very broad and difficult term to define. Grammatically, it can be both a noun and a verb. Two references from Heidegger's work define it most clearly. In Being and Time, Heidegger writes: "Everything we talk about, 
towards a more alluring freedom: the freedom from causality. Differently from Kant, who argues for a universe characterized by causality, Heidegger claims that causality is itself the product of freedom. In Heidegger's own words: "causality, movement, and being as such, are grounded in freedom." ${ }^{\text {29 }}$ Further, not only man, but also being and time, "causality, movement, and being as such, are grounded in freedom. ${ }^{\prime 30}$ This freedom appears inoffensive for politics because it is reserved purely for contemplating the universe as free of causality. Yet, just like Plato's conceptualization of a universe characterized by order had serious implications for how one could order his soul. So this conceptualization of the universe represents an invitation on Heidegger's behalf to explore limitless possibilities and, hence, a radical openness.

To summarize, even though Heidegger is himself critical of German Idealism and thus attempts to rectify its shortcomings, especially its radical subjectivity, his solutions to German Idealism often unleash new dangerous freedoms, while at other times they are susceptible to his own criticism. Moreover, the various freedoms that Heidegger's thought unleashes can appeal to tired liberals; though as this work will show, they are too radical to be incorporated within the liberal tradition.

everything we have in view, everything towards which we comport ourselves in any way, is being; what we are is being, and so is how we are. Being lies in the fact that something is, and in its Being as it is; in Reality; in presence-at-hand; in subsistence; in validity; in Dasein in the 'there is.'"(7) In An Introduction to Metaphysics, Heidegger also defines being as: "Permanent, always identical, already-there, given-all mean fundamentally the same: enduring presence, on as ousia (202). Thus, Being denotes a presence that includes all modes of existence, both physical, and metaphysical. My interpretation is not meant to exhaust the possibilities of its meaning; such an undertaking is simply impossible in the context of this work.

${ }^{29}$ Heidegger, Schelling's Treatise on the Essence of Human Freedom, 94.

${ }^{30}$ Ibid.,. 


\section{Breakdown of this work}

End of life issues provide powerful ways to evaluate Heidegger's work on freedom because they force his thought to confront matters of dying in real life experiences rather than in mere thought, and under the umbrella term of existentialism. This study thus examines five of the most relevant and contested issues about dying and death in the developed world and discusses each one of them in a separate chapter. These issues include: the right to die; suicide; the practice of euthanasia; the use of life support technology; and the possibility of immortality.

Each chapter begins by introducing the larger debates surrounding each particular subject mentioned above. To introduce these current debates, I draw primarily on the work of scholars in bioethics and, where appropriate, from the work of scientists in the biotechnological and medical sciences. Occasionally, I also will rely on historical accounts to trace changes in perceptions and practices surrounding these issues. I do so based on the premise that a good memory of how end of life issues were approached in the past, can help us understand them in the present, and better equip us to deal with these issues in the future.

After I introduce these larger debates, I narrow the focus of each chapter to particular elements in Heidegger's thought that are most pertinent to these debates. In the first chapter examining the right to die, the focus is on the relationship between autonomy and freedom. The second chapter on suicide examines the manner in which man is rooted into the world. The third chapter 
on the modern practice of euthanasia engages Heidegger's conceptualization of the role of empathy. The fourth chapter, dealing with life support technology, focuses on the interplay between art and politics, particularly between the theater and politics. Finally, the last chapter deals with immorality and engages Heidegger's work on temporality.

The first chapter begins with an overview of the legal environment in which discussions about euthanasia, suicide, and life support occur. The primary focus is on right to die arguments, and my intention is to ground these arguments within the larger philosophical tradition. Of particular importance here are the works of Arthur Schopenhauer and of Friedrich Nietzsche. While Schopenhauer was more systematic in his thought, Nietzsche's resistance to systematic thought, even including his own thought, makes his insight more difficult to engage. To compensate for this, I adopt Heidegger's interpretation of Nietzsche, not because I judge it to be correct, but because it is one of the most influential. Finally, this chapter demonstrates how activists in favor of the right to die are fascinated with freedom rather than preoccupied with justice in matters of dying and death. As such, their arguments reveal a misunderstanding about the just limits within which a liberal democratic state may intervene in individuals' lives. This misunderstanding is rooted in an understanding of freedom as an absolute escape from convention and nature. It is also an understanding of freedom as 'self-legislation.' However, while this radical freedom is dangerous to liberalism, it does serve an important role in Heidegger's seminal work Being and Time.

The second chapter examines suicide in its socio-historical context and demonstrates how certain conceptualizations of it are likely to be permanently 
altered especially as people enjoy longer life-spans. While suicide will continue to remain the most personal of actions, it is unlikely that forms of egoistic and anomic suicide will continue to be judged with the same severity as they once were in the past. Furthermore, the more recent trend of rationalizing suicide likely will become more entrenched in society, in part, because of the medical technology that prolongs the suffering that often accompanies dying. The danger with rationalizing suicide is that of using the possibility of suicide to actually prevent it. To better conceptualize the danger this represents, I turn to Heidegger's thought and elaborate the interplay between Dasein's Being-towardsdeath and care (Sorge) and relate it to two possible translations of Dasein as 'Being-Open' and 'Being-Here.' This chapter illustrates that while 'Being-Open' could theoretically be used to support suicide, the inherent connotations of 'Being-Here' necessarily oppose this action in practice.

In doing so, I clarify how suicide can be simultaneously an undesirable action as well as an instrumental thought experiment that psychiatrists and even bio-ethicists may be tempted to use to prevent suicide. I conclude by reiterating how the use of the possibility of one's death to grant one a firmer anchoring into 'this world' risks confusing 'Being-Open' to possibilities towards life with 'BeingOpen' to suicide.

The third chapter focuses on euthanasia and the standards used for judging the good death existing in the past. This chapter traces the root words for euthanasia to the ancient Greek words eu (good) and thanatos (death). This etymology implies that certain standards for judging the good death existed in the past and may still exist today. Based on this brief historical overview, I explain how judging the good death tended to be a private verdict passed on 
one's own life, or one passed by others; or one to be passed by God at the Day of Judgment. Yet, all of these judgments passed on one's death pertained more to how one lived than to how one actually died.

Following this history, I turn to the current understanding of euthanasia and show that modern arguments, based on mercy or empathy with the terminally ill, are similar to Heidegger's conceptualization of authentic-being-withothers. This chapter thus engages the relationship between 'the they' (das Man) and 'the others' and demonstrates how the relationship with others that makes empathy possible, and which Heidegger favors, is contingent on a common destiny that obliterates the tension between ethics and laws. As such, it is incompatible with our liberal understanding of politics. I also use 'the they' to illustrate more clearly some of the dangers inherent in the modern understanding of euthanasia. Finally, I conclude, that a proper understanding of mercy and empathy within the context of modern euthanasia would actually entail an argument against euthanasia rather than for it.

The fourth chapter deals with life support technology and how this technology makes the space and time previously reserved for contemplation about death accessible to man. In doing so, it forces man to gaze upon this threshold between life and death and to fight over its meaning. Indeed, the many lawsuits involving life support illustrate how man has come to legally reckon with this in-between stage of life. My intention is to engage with Heidegger's work on technology and to relate it to the current debates over life support. I concur, with Heidegger - that technology can take many forms, none of which is necessarily dangerous - and I argue, based on his work, but which I complement with insight from philosopher A.N. Whitehead and bioethicist Albert Jonsen, 
that technological thought, especially among medical practitioners, is necessarily amoral and, at the limit, murderous.

This chapter will not provide a systematic overview of the evolution of scientific thought in the West, on which Heidegger bases his work on technology, nor will it engage the vast literature on the philosophy of science. Instead, I focuses on certain elements, including assumptions, and elements of Greek drama present in modern science that play a defining role in shaping technological thought. My intention is two fold: to illustrate the source of some of the problems that emerge when this thought is applied to patients receiving life support; and to show that the question concerning technology need not be relegated to art, as Heidegger maintained, but also can be undertaken through politics.

The final chapter examines the possibility of immortality on this side of the grave. I ask the question: 'If men don't die, shall they still live?' as a means of guiding the reader back to early thinkers that asked, not only if men should live forever, but also how they should live. It will describe the current advancements in biotechnology and the alluring promises they make to individual human beings, while also outlining some of the great dangers individual immortality represents to the human species.

Finally, I argue that the physical immortality that biomedical technology may one day make possible will generate the false impression that time can be mastered. In this context, Heidegger's own insights on how the mastery of truth that typifies modern science and technology obliterates an authentic contemplation of Being, will be applied to his own conception of authentic temporality. Hence, I use Heidegger's later work on technology to criticize 
Heidegger's earlier concept of authentic temporality. Indeed Dasein's projection into the future is uncannily similar to the very root of the scientific method that projects hypotheses onto nature. Authentic temporality, in other words, aims at controlling time the way technology aims at controlling nature and they both result in the obliteration of Being. Thus, Heidegger's prudent reflection of Being as clearance from his later works contradicts his earlier aggressive and controlling impulse concerning the ability to act in time in his earlier works. This aggressive impulse can also be used to justify bringing about immortality on this side of the grave.

I conclude by speculating on how an immortal may live. I postulate that a world where men could continuously fend off death through biomedical technology, would be dominated by a ubiquitous fear of death about which men would no longer dare talk: a world that risks losing the aptitude to engage in meaningful discourse over the meaning of life because they would have lost the ability to contemplate, not 'Being,' but 'time' in their preoccupation with mastering it.

Finally, this work demonstrates that Heidegger's thought is threatening to elements of negative freedom in liberal thought, and politics in general. If elements of his thought are infused into modern ethical views about dying and death, then they can only be used out of context and contrary to what Heidegger intended. In short, Heideggerian insights and concepts can only enrich our ethical tradition if we do violence to Heidegger's thought by re-interpreting it in a way in which he did not intend and also in ways he would be unlikely to approve. If his insights and concepts are used literally, respecting the larger 
context in which they were derived, then they would be corrosive to liberal democratic principles underlying our modern medical ethics. 


\section{Chapter 1. The fascination with freedom in the right to die}

In 1997, The Oregon Death with Dignity Act challenged the traditional liberal understanding of rights that began with Hobbes by creating a new right: the right to die. A decade later, in 2008, during the general election, Washington State followed suit and approved the Washington Aid-In-Dying initiative. Strong advocates for this legislation invoked the language of liberty and autonomy to justify their cause. Not surprisingly, this approach continues to be controversial. According to strong supporters of this legislation, the only impediment to having a right to die is the law, and if the law changes, then public opinion will follow. This was indeed the case with the Oregon Act. The Act was adopted in 1994 in a general election with a narrow margin of $51 \%$. By 1997, the state legislation appealed the Act and residents of Oregon this time supported it with a $60 \%$ majority, demonstrating the laws' ability to legitimize the practice.

Yet, the two also reinforce each other and a change in public opinion can result in a change in legislation. This reasoning is not new. Dr. Charles Potter, the founder of Euthanasia Society of America (ESA) had articulated this point back in 1938. Potter once wrote that "Public opinion...is the only morality, as sociologists well know, even if clergymen do not. The law may warn; medical ethics may frown; and the church may threaten with the fires of hell, but public opinion is stronger than all three." Consequently current activists for the right to

\footnotetext{
${ }^{1}$ Shai J. Lavi, The Modern Art of Dying: A history of euthanasia in the United States
} (Princeton: Princeton University Press, 2005), 99. 
die have attempted to mobilize public opinion through advertisements in the media, and to lobby governments to promote legal change.

Additionally, scholars of bioethics that also endorse the right to die have realized that more thorough intellectual arguments are needed to justify the right to die. Some have turned to philosophy to find such justifications. Yet, although scholars reference thinkers like Friedrich Nietzsche and Arthur Schopenhauer, they do so often in passing in the form of 'catchy' phrases seldom elaborated at length or even well contextualized. This often produces powerful and even dangerously alluring sense of legitimacy for the right to die.

In light of this, this work provides a more focused philosophical interpretation of the debates over the right to die. My intention is to illustrate how the use of philosophy to justify the right to die reveals a fascination with freedom rather than a preoccupation with justice in matters of dying and death. When these references to philosophy are analyzed in their original philosophical context, they are revealed to undermine the basic premises of social contract on which liberalism is founded. The radical understanding of freedom, which mostly typifies Nietzsche's thought, can be accommodated by Heidegger's seminal work Being and Time, it is incompatible with liberal principles.

\section{The right to die in brief context}

The controversy over the right to die applies mainly to the practice of euthanasia both passive (when another party is only indirectly involved in someone's death), and active (when another party directly brings about someone's death), 
and to some of the difficult choices made in the Intensive Care Unit; but not to suicide. In the case of suicide, the right to die does not apply because suicide has been decriminalized in most of the developed world to make it easier for people who contemplate suicide to ask for help. Thus, in the case of suicide the legal system does not require any changes. In the case of the Intensive Care Unit, where patients depend on machines to remain alive, when the formidable decision to remove them does cause their death, this is considered legal because the patient is 'allowed to die'. The legal provision, however, for aiding someone to die directly by administrating a lethal injection, for instance, or indirectly by prescribing lethal drugs, continues to be controversial and it is this practice that the right to die aims to protect under law.

Historically, the initial inspiration for right to die advocacy in Britain and the United States came from birth control advocates. Indeed, an early slogan that was suggested to the Euthanasia Society of America read "Legalize Death Control. ${ }^{\prime 2}$ In the 1930s, the reasons invoked for right to die legislation pertained to the health of society and they were closely connected with eugenics laws. They did not invoke, as they do now, the freedom or autonomy of the individual to justify the right to die. Instead, they reflected intellectual arguments made in Nazi Germany, for the good of science, the advancement of knowledge, and the benefit to society and to national interest. ${ }^{3}$ After the atrocities of Nazi Germany became known, public opinion in America became increasingly opposed to the right to die and the ESA had to focus on changing the law instead of changing

\footnotetext{
${ }^{2}$ Lavi, The Modern Art of Dying, 103.

${ }^{3}$ Wesley J. Smith, Culture of Death: The Assault on Medical Ethics in America (San Francisco: Encounter Books, 2000), 47.
} 
public opinion. Hence, the role of the law, as Shai Lavi pointed out, "was no longer to judge whether the practice of euthanasia was just but to secure the regulation of technique." ${ }^{4}$ An efficient way of securing this practice is by recognizing it as a basic human right and consequently protecting it under the constitution. It is in this context that the efforts of current advocates for the right to die are best understood.

Currently, there are numerous right to die organizations. Back in 1980, 44 of these organizations representing 25 countries came together under the umbrella of The World Federation of Right to Die Societies. ${ }^{5}$ The 44 organizations agreed that The World of Right to Die Societies Federation would provide "an international link for organizations working to secure or protect the rights of individuals to self-determination at the end of their lives." The federation summarized its views in its manifesto that read:

The World Federation of Right to Die Societies ... is aware of the increasing concern to many individuals over their right to die with dignity. Believing in the rights and freedom of all persons, we affirm this right to die with dignity, meaning in peace and without suffering....The voluntarily expressed will of individuals, once they are fully informed of their diagnosis, prognosis and available means of relief, should be respected by all concerned as an expression of

\footnotetext{
${ }^{4}$ Lavi, The Modern Art of Dying, 125.

${ }^{5}$ Three of these organizations are from Canada: Association Quebecoise pour le Droit de Mourir dans la Dignite, Dying with Dignity, and Right to Die Society of Canada.
} 
intrinsic human rights. ${ }^{6}$

One of the most influential supporters of the Federation is Derek Humphry, who also presided over this Federation in the early 2000s. Humphry's justification for the right to die also invokes the tradition of rights. In his manual on 'selfdeliverance' titled Final Exit, he pays particular attention to the legality involved and dedicates an entire chapter to legal concerns. "Helping another person to die, [he writes] is presently against the law. ... Hopefully the time is not far off when the law will be modified to permit physician aid-in-dying but we are not there yet." 7

Humphry's influence in promoting right to die legislation cannot be overstated. As an individual he even practices what he preaches. As he writes in Final Exit: "I have helped three people to die - my first wife, my brother, and my father-in-law." ${ }^{8} \mathrm{He}$ explains how he handled the legal authorities in the aftermath and also describes the legal loopholes he benefited from. Humphry also funded the Hemlock Society in 1980, a non-profit organization that attained a sound financial standing of 3 million dollars in $2003 .{ }^{9}$ The Hemlock Society supported ballot initiative for the right to die in California, Michigan, Maine, and, of course, Oregon and Washington State. ${ }^{10}$

\footnotetext{
${ }^{6}$ The World Federation of Right to Die Societies, "Toronto Manifesto." Accessed September 6, 2010. http://www.worldrtd.net/node/840

${ }^{7}$ Derek Humphry, Final Exit: The practicalities of self-deliverance and assisted suicide of the dying (New York: Bantam Doubleday Dell Publishing Group Inc., 1991), 13. ${ }^{8}$ Ibid., 108.

9 Euthanasia Research Guidance Organization. Accessed November 29, 2010. http: / / www .assistedsuicide.org/farewell-to-hemlock.html

${ }^{10}$ rbid.
} 
Yet, because of the many restrictions built into The Oregon Death with Dignity Act and The Washington Aid-In-Dying Initiative, these acts represent only a partial victory for Humphry and other right to die activists. They aim to achieve a universal human right to die. This goal was clearly articulated by Humphry himself: "I hope we are all here - as I am - fighting for the ultimate civil liberty, the right to choose to die when we wish and how we wish, no matter what it is called."11 Aside from an appeal to compassion for the suffering, Humphry does not discuss the implications of the right to die in broader philosophical or religious perspectives, remaining loyal throughout his work to his understanding of 'basic human rights.'

Activists like Humphry, who pressure the legal system to include this new right, also include bioethicists engaging philosophical works to find additional support for the right to die. Accordingly, thinking about the right to die in a broader philosophical context helps clarify and raises awareness about some of the larger political and legal implications of this contentious right.

Although the notion of rights was first introduced by Thomas Hobbes, the right to die is neither rooted in this tradition, nor can it be supported with textual evidence from its founder. Thomas Hobbes, after all, not only created the Leviathan to escape death at the hands of others, but he also maintained that "A Law of nature is a Percept, or generall Rule, found out by Reason, by which a man is forbidden to do, that, which is destructive of his life." ${ }^{\prime 2}$ Along similar lines, his successor, John Locke, wrote: "But though this be a State of Liberty, yet it is not a State of License, though Man in that State have an uncontrollable

\footnotetext{
${ }^{11}$ Accessed November 26, 2010. www. assistedsuicide.org

${ }^{12}$ Thomas Hobbes, The Leviathan (London: Penguin Books, 1968), 189.
} 
Liberty, to dispose of his Person or Possessions, yet he has not Liberty to destroy himself."13 From a liberal perspective the right to die is nonsensical because individuals join the social contract to preserve their lives and it is precisely this idea that the right to die undermines. Indeed, if the state determines when it is appropriate to terminate one's life, then the state refuses to honor its contract and to provide security to its citizens.

Infusing the right to die in our liberal tradition also undermines a preexisting basic human right: the right to life. Judged from within the liberal tradition of rights, the right to die marks a departure from this tradition because it is a refusal of rights. Nor can it be argued that the right to die benefits the patient because, once enforced, the patient is expected to die; not to recover. Moreover, this new right also jeopardizes the medical practice because it would force doctors to agree to a contract that results in the death of their patients. This would contradict the Hippocratic Oath to which they swear: a staple of Western medical ethics.

The difficulty of arguing in favor of state intervention to guarantee the right to die under a liberal democratic framework has prompted scholars to turn their attention to other philosophers to justify this right. Some notable examples include an appeal to German thinkers Arthur Schopenhauer and Friedrich Nietzsche in particular, and occasionally even Immanuel Kant. Even though neither Schopenhauer nor Nietzsche belonged to the liberal tradition, 'right to die activists often use these philosophers' jargon to support their cause. In so

${ }^{13}$ John Locke, The Second Treatise of Government (New York: Cambridge UP, 1993), 311. 
doing, they conjure up a morbid scenario where taking one's life is a desirable undertaking that the law must permit and that the state must ensure.

Perhaps, for the reasons outlined above, activists for the right to die do not invoke the liberal tradition of rights, opting instead to rely on the ideas of mainland philosophers, especially German. Occasionally they have used Kant's notion of 'autonomy' to justify this right. However, as Leon Kass points out, this is particularly misleading. ${ }^{14}$ Indeed, the categorical imperative - "act only on that maxim whereby thou canst at the same time will that should become a universal law"15 - if applied to the right to die, becomes nonsensical. A right to die implies that a person opting for it would expect others to do the same under similar circumstances. Kant writes explicitly against this, stating: "to destroy the subject of morality in his own person is tantamount to obliterating from the world, as far as he can, the very existence of morality itself; but morality is, nevertheless, an end in itself." ${ }^{\prime 16}$ Autonomy for Kant means one acts according to universal reason and that nature endows men with the ability to discern the rational maxim. In sum, autonomy, for Kant, is duty bound to reason; not a carte blanche for doing as one pleases. It is compatible with self-restraint, rather than with selfindulgence. $^{17}$

More often, however, proponents for the right to die invoke radical German thinkers, particularly Arthur Schopenhauer and Friedrich Nietzsche. In fairness to both Schopenhauer and Nietzsche, who argued for a right to die, it

${ }^{14}$ Leon R. Kass, Life Liberty and the Defense of Dignity, 216.

${ }^{15}$ Immanuel Kant, "Fundamental Principles of the Metaphysics of Morals," in Basic Writings of Kant, ed. Allen W. Wood, (New York: Modern Library, 2001), 178.

${ }^{16}$ Kass, Life Liberty and the Defense of Dignity, 216.

${ }^{17}$ Ibid. 
should be acknowledged that neither of them belonged to the liberal tradition, nor did they attempt to enrich this tradition. Schopenhauer, for instance, roots the right to die in nihilistic philosophy, while Nietzsche roots it in a radical understanding of freedom. Heidegger defined this radical freedom as the freedom to self-legislate, or "to stand within one's own essential law." ${ }^{18}$ This is a freedom that involves a radical assertion of the subject. Consequently, it is a freedom that is radically subjective, and for this reason, cannot be invoked to support any universal notion of human rights, especially not a universal human right to die.

\section{Schopenhauer and the right to die}

It was Arthur Schopenhauer who, launching his attack primarily against the Judeo-Christian view of suicide, used the word 'right' in this context. He writes: "we hear that suicide is the most cowardly of acts, that only a madman would commit it, and similar insipidities; or the senseless assertion that suicide is 'wrong,' though it is obvious there is nothing in the world a man has a more incontestable right than to his own life and person." ${ }^{19}$ Not coincidentally, this phrase found its way into more mainstream scholarly works, though most of these works aim in some way to temper Schopenhauer's unapologetic support for the right to end one's own life. The references to Schopenhauer as a source of authority are interesting because he roots the right to die in the right to life by

\footnotetext{
${ }^{18}$ Heidegger, Schelling's Treatise on the Essence of Human Freedom, 84.

${ }^{19}$ Arthur Schopenhauer, Essays and Aphorisms, trans. R. J. Hollingdale (London: Penguin Books, 1970), 77.
} 
rooting life in the idea of nothingness. Simply put, he maintains that non-Being is a condition closer to 'truth' than 'being' and that death is more in tune with nature than life.

According to Schopenhauer matters of right and wrong cannot be decided by a philosophical pursuit of truth, but by a proper understanding of the will-to-life, which is innate in both nature qua nature as well as man's nature. As he writes: "For here, where it is a question of the worth or worthlessness of existence, of salvation or damnation, not the dead concepts of philosophy decide the matter, but the innermost nature of man himself." And, he continues:

Virtue is as little taught as is genius; indeed, the concept is just as fruitful for it as it is for art, and in the case of both can be used only as an instrument. We should therefore be just as foolish to expect that our moral systems and ethics would create virtuous, noble, and holy men, as that our aesthetics would produce poets, painters and musicians. ${ }^{20}$

While virtue cannot be taught, will is as innate in man as it is in nature. Schopenhauer constructs percepts of right and wrong based on this conceptualization of will as innate in nature. Differently from the Ancient Greek philosophers, who regarded nature as a higher order from which one could derive a moral order, for Schopenhauer nature is typified by a will-to-life that is innate in all men.

The concept of will in Schopenhauer differs from previous conceptualizations. For St. Augustine, for instance, will is innate. "I knew I had a

${ }^{20}$ Arthur Schopenhauer, The World as Will and Representation, trans. E.F.J. Payne (New York: Dover Publications, Inc., 1969), 271. 
will," [he writes "as surely as I knew that there was life in me." ${ }^{21}$ Will is not life itself, but rather the ability of the mind to command the mind, or, more accurately, the ability to oblige the mind into obedience to God and to deny one's own misplaced will to follow God's will. ${ }^{22}$ In this manner, will becomes, as St. Augustine argues, free will. In response to St. Augustine and the Christian understanding of will, Schopenhauer writes: "it is indeed a palpable contradiction to call the will free and yet to prescribe for it laws by which it is to will. “Ought to will! Wooden-iron."

A more modern conceptualization of the will is present in Hobbes. For Hobbes the will is "the last Appetite, or Aversion, immediately adhering to the action, or to the omission thereof. ${ }^{23}$ While will is an attribute of the Sovereign, who is the soul of the Leviathan, ${ }^{24}$ it becomes so only after it aggregates all men's wills ${ }^{25}$ to escape the fear of death. Thus, even though the will becomes that of the Sovereign in The Leviathan, at least prior to forming a covenant, man is understood to possess will because without it, he would not be able to transfer his right to all things "in a voluntary act of his own." ${ }^{26}$ For Hobbes, then, the will is connected to man's ability to act.

In an indirect response to Hobbes' understanding of will, Schopenhauer writes: "but in the light of our whole view, the will is not only free, but even almighty; from it comes not only its action, but also its world; and as the will is,

${ }^{21}$ St. Augustine, Confessions, trans. R.S. Pine-Coffin (London: Penguin Books, 1961) VIII, Ch. 9, 172.

${ }^{22}$ St. Augustine, Confessions, Book X, Ch. 1, p. 181.

${ }^{23}$ Hobbes, Leviathan, Ch. 6, p. 127.

${ }^{24}$ Ibid. Introduction, p. 81.

${ }^{25}$ Ibid., Ch. 17, p 227.

${ }^{26}$ Ibid., Ch., 14, p. 191. 
so does its action appear, so does its world appear; both are its self-knowledge and nothing more. ${ }^{\prime 27}$ According to Schopenhauer, not only action but also, as the tile of his book indicates, metaphysics is the product of the will.

The will-to-life, as Schopenhauer understands it, is present in all animals. Their knowledge of the world is such, however, that it "remains subordinate to the service of the will, as indeed it came into being for this service; in fact, it sprang from the will, so to speak, as the head from the trunk." In man, "whose head seems freely set on the body, only carried by the body and not serving $\mathrm{it}^{\prime 28}$ the will can be suspended in contemplation. While most men are guided by the will-to-life and are satisfied with this condition, men of genius are able to step out of their self-interest and to deny their will-to-life. ${ }^{29}$ Thus, by denying his will to life, man sets himself 'above' nature.

'Right' and 'wrong' become rooted in this understanding of will. Schopenhauer argues that, since will is present in all men, and it asserts itself in survival and procreation to deny another man his will, "breaking through the boundary of another's affirmation of will" is wrong. ${ }^{30}$ Consequently, slavery, seizing one's property, that is the product of one's labor, murder, and in sum anything that would compel, either through violence, lies or cunning, an individual to serve another man's will rather than his own, is wrong. ${ }^{31}$ To break a contract is also wrong because, by breaking it, one party deceives another and gains an unfair advantage over the other's will. The negation of wrong is right.

${ }^{27}$ Schopenhauer, The World as Will and Representation, 272.

${ }^{28}$ Ibid., 177.

${ }^{29}$ Ibid., 186.

${ }^{30}$ Ibid., 334.

${ }^{31}$ Tbid., 335. 
This entails not infringing on another's will. The implications these concepts have for Schopenhauer's views on government are beyond the scope of this paper. ${ }^{32}$ It is important to point out, however, that will-to-life, as understood by Schopenhauer, grants the individual no right to limit another person's will-tolife; only absolute autonomy over his own life.

Schopenhauer also makes possible a conceptual merger of the right to die with the right to life. He does so through the idea of nothingness. The idea of nothingness is relative to something, since an absolute 'Nothing' can only be conceived in relation to something that is. Schopenhauer agrees with Plato's argument in The Sophist that every absolute nothing must be subordinated to something higher that it negates. By negating it, it in fact affirms it. Like Plato, he calls the universally positive Being. For Schopenhauer, Being corresponds to the world of representation. He writes: "What is universally assumed as positive, what we call being ... is exactly the world as representation, which I have shown

${ }^{32}$ Schopenhauer derives right and wrong from the will-to-life and he argues that these remain moral even if they are not enforced in the state of nature. In this manner, Schopenhauer attempts to revert Hobbes' argument for rights and return it to a novel form of positive law. He writes:

"Now whoever wishes to set aside the purely moral consideration of human conduct, or to deny it, and to consider conduct merely according to its external effect and the result thereof, can certainly, with Hobbes, declare right and wrong to be conventional determinations arbitrarily assumed, and thus not existing at all outside of positive law (...) hence we can just as little explain to him the a priori of mathematics as the a priori nature of right, because he pays no heed to any knowledge that is not empirical. (p. 342)

Schopenhauer distinguishes between positive and negative freedoms and advocates that the state must focus only on the later since "positive legislation is the establishment of a positive wrong, it is a publicly avowed enforced wrong." (p. 346) The state's authority cannot be focused on changing individuals' egoism because it is rooted in their will-to-life, "but only against the injurious consequences of egoism arising out of the plurality of egoistic individuals" (p. 345). Thus, for Schopenhauer the purpose of the state is not to improve man's condition but to punish wrongdoings. 
to be the objectivity, the mirror, of the will. We ourselves are also this will and this world, and to it belongs the representation in general as one aspect of it." ${ }^{\prime 33}$ Yet, because we are alive, we are also subject to the will-to-life and thus cannot conceive of the world outside of our being. For, according to Schopenhauer:

So long as we ourselves are the will-to-life, this last, namely the nothing as that which exists, can be known and expressed by us only negatively, since the old saying of Empedocles, that like can be known only by like, deprives us here of all knowledge, just as, conversely, on it ultimately rests the possibility of all our actual knowledge, in other words, the world as representation, or the objectivity of the will; for the world is the self-knowledge of the will. ${ }^{34}$

Hence, viewing the will-to-life as a vehicle for gaining knowledge of Being is akin to contemplating the possibility of its absence; or 'non-Being.' In more dramatic but accurate terms, Schopenhauer's insight amounts to the realization that life gets in the way of properly knowing the world as it is (i.e. the world devoid of will).

From here, his argument continues towards the insight that most troubled Nietzsche. Schopenhauer writes:

If, however, it should be absolutely insisted on that somehow a positive knowledge is to be acquired of what philosophy can express only negatively as denial of the will, nothing would be left but to refer to that state which is experienced by all who have attained to

${ }^{33}$ Schopenhauer, The World as Will and Representation, 410.

${ }^{34}$ Ibid. 
complete denial of the will, and which is denoted by the names ecstasy, rapture, illumination, union with God and so on. ${ }^{35}$

This state of denial of the will-to-life, Schopenhauer agrees, would no longer involve a commitment to knowledge let alone philosophy. Rather, it would be a state of contemplation or meditation, not of philosophical pursuit. Schopenhauer reserves, however, a role for reason to outline the possibility of a denial of a willto-life; or to think "No will: [and therefore] no representation, no world." Those who achieve this denial of the will to life are able to understand the world as it is: which is to say as nothing. For, "to those in whom the will has turned and denied itself," he writes "this very real world of ours with all its suns and galaxies, is nothing." ${ }^{36}$

In sum, according to Schopenhauer, will is not a quality of man's soul that can be directed towards God, or that can prompt one to action, as Hobbes contends. Rather, the will-to-life directs man's life. The only way man can free himself from the ubiquitous and omnipotent will-to-life and rise above his condition of a being that is pre-ordained by the will of nature to live, grow and procreate, is to deny it. Man can deny his will to life by accepting that he came form nothing and that to nothing he shall return; and by contemplating himself even now, while alive, as not here and not now, not yet born or, which would amount to the same thing, already dead.

Death, when properly contextualized in Schopenhauer's work, emerges as more primordial than life. At times, death even looms over life itself in Schopenhauer's work. In his own words: "Death is like the setting of the sun,

${ }^{35}$ Schopenhauer, The World as Will and Representation, 410.

${ }^{36}$ Ibid., 412. 
which is only apparently engulfed by the night, but actually, itself the source of all light, burns without intermission, brings new days to new worlds, and is always rising and always setting. ${ }^{137}$ Death, in other words, is itself more natural than life.

Despite his poetic and almost alluring words about death, Schopenhauer does not advocate suicide. Quite the opposite: he argues that suicide does not deny the will, but rather affirms it. He writes: "far from being a denial of the will, suicide is a phenomenon of the will's strong affirmation. ${ }^{\prime 38}$ This is because all life naturally leads towards death and suicide only speeds up a process already preordained by nature's will. As such, Schopenhauer does not advocate for suicide because suicide would deny man the possibility of an "ocean-like calmness of the spirit" from which "the will has vanished"39 and which can only exist while one is alive. In less poetic form, suicide denies man the possibility of contemplating non-Being: the highest or most honest pursuit a man can undertake in thought.

Yet, even though Schopenhauer does not advocate suicide, nor can he logically condemn it. This is because he rooted suicide in an affirmation of the will. Suicide, in other words, becomes the natural ramification of his understanding that everything that is alive tends towards the 'natural' condition of being dead, and suicide represents a mere acceleration of this process.

Meanwhile, the argument for a right to die, approached from Schopenhauer's perspective, is rooted in life because life itself is merely a curtain

${ }^{37}$ Schopenhauer, The World as Will and Representation, 336.

${ }^{38}$ Ibid., 398.

${ }^{39}$ Ibid., 411. 
that makes man temporarily oblivious to his own death. Man can see past this curtain because he is able to deny his will-to-life and to contemplate life as nothingness. Also, according to Schopenhauer, the right to life implies the right to kill oneself because life itself is rooted in the idea of non-Being (or nothingness). This radical nihilism resting behind Schopenhauer's support for the right to die is seldom acknowledged when scholars quote Schopenhauer as the authority on the right to die.

Furthermore, while Schopenhauer might not object to suicide, he would strongly object to euthanasia, the most common situation for which the right to die is invoked, because euthanasia involves making a decision about someone else's will-to-life. This, according to Schopenhauer, is indeed wrong. He would therefore reject the use of his thought by bioethicist Margaret Battin, for instance, who argues that in his support for the right to die, Schopenhauer is "appealing to a notion of suicide as what we might consider an act of ultimate dignity: the final act of self-determination and self-affirmation in an immoral, and unyielding world. ${ }^{\prime 40}$ On the contrary, Schopenhauer argues that the highest self-affirmation is a denial of the will-to-live, while one is alive, not in bringing about one's own death.

\section{Metaphors of creation about the right to die}

Friedrich Nietzsche advances the most virulent argument for the right to die. This argument is bound up in Nietzsche's struggle against Schopenhauer's

\footnotetext{
${ }^{40}$ Margaret Pabst Battin, The Least Worst Death: Essays in Bioethics on the End of Life (Oxford: Oxford University Press, 1994), 286.
} 
argument for the denial of the will-to-life. Nietzsche criticizes Schopenhauer's understanding of the will for two reasons; because Schopenhauer assumes will to be omnipresent and uniformly expressed thus lacking in nuance; and because the prospect of its denial is not dignifying for man. Regarding the first criticism, Nietzsche argues that, Schopenhauer "never even attempted an analysis of the will because, like everybody else, he had faith in the simplicity and immediacy of all willing. ${ }^{\prime \prime 1}$ Regarding the second criticism, Nietzsche argues that confronting nihilism opens up the possibility "to the opposite ideal: the ideal of the most high-spirited, alive, and world-affirming human being." ${ }^{\prime \prime 2}$ Schopenhauer also contemplated this possibility, ${ }^{43}$ but he did not develop it to the same extent that Nietzsche did. Nietzsche addressed both of those through eternal recurrence or return.

However, since Nietzsche's work is largely unsystematic and subject to significant scholarly debate, I will rely here on Heidegger's interpretation of Nietzsche, derived from his famous four-volume work. This is not necessarily because I believe Heidegger's reading to be correct, but because it is the first and

${ }^{41}$ Friedrich Nietzsche, The Gay Science, trans. Walter Kaufmann (New York: Vintage Books, 1974) Aphorism 127.

${ }^{42}$ Friedrich Nietzsche, Beyond Good and Evil, trans. Walter Kaufmann (New York: Vintage Books, 1996) Aphorism 56.

${ }^{43}$ The seed for eternal recurrence was already present in Schopenhauer. In The World as Will and Representation he writes: "A man who had assimilated firmly into his way of thinking the truths so far advanced, but at the same time had not come to know, through his own experience or through a deeper insight, that constant suffering is essential to all life; who found satisfaction in life and took perfect delight in it; who desired, in spite of calm deliberation that the course of his life as he had hitherto experienced it should be of endless duration or of constant recurrence; and whose courage to face life was so great that, in return for life's pleasures, he would willingly and gladly put up with all the hardships and miseries to which it is subject; such a man would stand 'with firm strong bones on the well-grounded, enduring earth' and would have nothing to fear." 284. 
most influential attempt to systematize Nietzsche's thought. Moreover, Nietzsche himself did not develop a cohesive view of eternal recurrence and it could indeed be argued that such cohesiveness contradicts his principles. He was, after all, a thinker that lost interest in his own thoughts and even admonished them. ${ }^{44}$ Heidegger's work on Nietzsche, however, continues to influence modern readings of Nietzsche.

Eternal recurrence, in Heidegger's Nietzsche, is both meant to remind nihilists that they have 'life thrust upon them' and ought to enjoy it rather than contemplate non-Being, and meant to rescue 'the strong' from the shackles of false morality imposed on them by the notion of absolute truth. Eternal recurrence promises to liberate both because it roots life in life rather than in nonBeing. This restores man's creative ability by allowing him to create his own life, while also returning to him his will-to-life. Thus, eternal recurrence is a condition in which man wills, then acts inspired by this will, then suffers the repercussions or enjoys the successes of his actions. He then recreates himself in such a manner as to take into account the actions performed to will yet again, to suffer or to enjoy, and to recreate once more and many times over. It grants man the ability, as Nietzsche writes:

To impose upon becoming the character of being - that is the supreme will to power.

Twofold falsification, on the part of the senses and of the spirit, to preserve a world of that which is, which abides, which is equivalent, etc.

\footnotetext{
${ }^{44}$ Nietzsche, Beyond Good and Evil, Aphorism 296.
} 
That everything recurs is the closest approximation of a world of becoming to a world of being: - high point of the meditation. ${ }^{45}$

This high point of meditation is also the greatest weight ${ }^{46}$ because, in the confines of eternal recurrence, man becomes his own redeemer and his own creator. He must, as Heidegger points out in reference to Nietzsche's philosophy, affirm life in its extreme anguish and in its most rollicking joy and do so alone. ${ }^{47}$ Failure to overcome life's difficulties and failure to create and re-create one's life becomes solely his own burden: a heavy burden for any human no matter how strong, how free-spirited, or how creative. Nietzsche foreshadows a possible reaction to the prospect of eternal recurrence when he writes, "would you not throw yourself down and gnash your teeth and curse the demon that spoke thus?" 48

Unlike Schopenhauer, who takes will for granted and maintains that it is equally present in man as it is in animals and in all life forms in general, Nietzsche differentiates amongst the will-to-life and the will to create. The willto-life, according to Nietzsche, typifies all life on Earth. The will to create on the other hand is unique to man and is best understood as artistic creativity. This artistic creativity includes, according to Nietzsche, philosophical thought. The will to life in nature, according to Nietzsche, "expresses itself in the interpretation, in the manner in which force is used up; transformation of energy

45 Friedrich Nietzsche, The Will to Power, trans. Walter Kaufmann and R. J. Hollingdale (New York: Vintage Books, 1967) Aphorism 617.

${ }^{46}$ Nietzsche, The Gay Science, Aphorism 341.

${ }^{47}$ Martin Heidegger, Nietzsche, trans. by David Farrell Krell (San Francisco: Harper Collins, 1991), 34.

${ }^{48}$ Nietzsche, The Gay Science, Aphorism 341. 
into life, and 'life at its highest potency' thus appears as the goal." ${ }^{\prime 4}$ As a natural corollary of this strife for power, life aims at mastering. "The will to power interprets ... it defines limits, determines degrees, variations of power... In fact, interpretation is itself a means of becoming master of something. (the organic process constantly presupposes interpretations). ${ }^{\prime 50}$ Hence, the will-to-life in nature manifests itself in the mastering of the inorganic matter to make it fit life's biological functions.

In nature, biological beings exist in a state of eternal recurrence. The chapter "The Convalescent" in Thus Spoke Zarathustra metaphorically exemplifies this type of eternal recurrence through a personification of Zarathustra's animals. The animals surround Zarathustra during his recovery and wait for Zarathustra's message but he does not speak. Instead, he tells the animals to speak: "'O my animals,' answered Zarathustra, 'go on talking and let me listen! Your talking is such refreshment."'51 Their refreshing words are: "everything goes, everything returns; the wheel of existence rolls for ever. Everything dies, everything a blossom anew; the year of existence runs on for ever. ${ }^{152}$ Here the animals talk about a form of eternal recurrence that is their own state of existence driven by the will-to-life. The animals exist eternally in the confines of their own species. Their birth, life, and death are part of a cycle that repeats perpetually with each new generation.

\footnotetext{
${ }^{49}$ Nietzsche, The Will to Power, Aphorism 639.

${ }^{50}$ Ibid., Aphorism 643.

${ }^{51}$ Friedrich Nietzsche, Thus Spoke Zarathustra, trans. R. J. Hollingdale (London: Penguin Books, 1969), 234.

52 Ibid., 234.
} 
The animals' existence recurs eternally, but they lack awareness about the kind of eternal recurrence Nietzsche advocates. The animals do not know that the future and the past are both part of an eternally circular time held together by the present, and that this present holds the moment when one can strive to will his own recurrence. As Heidegger explains:

What does all this say about the right way to think the thought of eternal recurrence? It says something essential: That which is to come is precisely a matter for decision, since the ring is not closed in some remote infinity but possesses its unbroken closure in the Moment, as the center of the striving; what recurs - if it is to recur - is decided by the Moment and by the force with which the Moment can cope with whatever in it is repelled by such striving. ${ }^{53}$

The type of eternal recurrence that typifies the animals, as well as the nihilists, is devoid of any realization that, though everything reoccurs, it does not need to reoccur indifferent to one's will. On the contrary, everything that reoccurs, at least according to Heidegger's interpretation of Nietzsche's work, must matter and that nothing is a matter of indifference. ${ }^{54}$ It must also reflect the fact that, as Heidegger continues, "we transpose ourselves to the temporality of independent action and decision, glancing ahead at what is assigned us as our task and back at what is given us as our endowment. ${ }^{\prime \prime 55}$ It must reflect, the fact that, differently from the nihilists, one can act, and must act, so as not to remain a passive spectator of his own life.

\footnotetext{
${ }^{53}$ Heidegger, Nietzsche, 54.

${ }^{54}$ Ibid., 182.

${ }^{55}$ Ibid.
} 
The eternal recurrence that is becoming of man, according to Nietzsche is more comprehensive than the type that typifies the animals. For this reason, Zarathustra finds their words mocking, and accuses them of making "hurdygurdy song of it." ${ }^{\prime 56}$ The animals' eternal recurrence even disgusts Zarathustra because it applies to both the week and the strong. He states:

Alas, man recurs eternally! The little man recurs eternally!

I had seen them both naked, the greatest man and the smallest man: all too similar to one another, even the greatest all too human!

The greatest all too small - that was my disgust at man! And eternal recurrence even for the smallest! That was my disgust at all existence. ${ }^{57}$

Eternal recurrence in the biological sense is therefore not desirable for Nietzsche because it is uniform across all life forms on Earth. It equates the strong with the weak by ensuring biological continuity to both. The eternal recurrence Nietzsche advocates is thus less democratic and necessitates a different will from the willto-life: the will to act and to create. ${ }^{58}$

The importance of the will to create in one's life, in Heidegger's Nietzsche cannot be overstated. Here, I will briefly outline the broad spectrum on which it expresses itself in one's life. In short, the will to create rests behind both metaphysical truths and artistic expression. Moreover, and particularly significant for this work, the will to create can infuse this intense artistic creativity into one's own life and, in this manner, help man to even reach past his life in order to orchestrate his own death.

\footnotetext{
${ }^{56}$ Nietzsche, Thus Spoke Zarathustra, 235.

${ }^{57}$ Ibid., 236.

${ }^{58}$ Nietzsche, The Gay Science, Aphorism 127.
} 
The ability to create is commonly attributed to artists and indeed Nietzsche understands art and artists in the broader context of creation. Artists, Nietzsche maintains, cannot endure reality. Plato, he argues, "as the artist he was, preferred appearance to being! Lie and invention of truth!" ${ }^{159}$ This partially accounts for Nietzsche's reliance on procreation or carnal metaphors to describe art and artists. Examples in passing include: "Artists, if they are any good, are (physically as well) strong, full of surplus energy, powerful animals, sensual" ; "Making music is another way of making children" ${ }^{\prime 60}$; "Art reminds us of states of animal vigor" ${ }^{\prime \prime 1}$; art originates from "the cerebral system bursting with sexual energy $^{\prime \prime 62}$ and art is sensuality in disguise. ${ }^{63}$ Thus, art, like truth, is also a manifestation of the will-to-life, yet it is a creative endeavor "worth more than truth. ${ }^{\prime 64}$ Or, as Heidegger wrote: "Art, as transfiguration, is more enhancing to life than truth, as fixation of an apparition." ${ }^{\prime \prime 65}$ Or in Nietzsche's charming words: "We possess art lest we perish from the truth."${ }^{\prime 66}$

Thus, according to Nietzsche, the will to create can manifest itself in the creation of truth, where truth is "the will to be master over the multiplicity of sensations: - to classify phenomena into different categories. ${ }^{167}$ The will to create generates truth as a concept in itself. In Nietzsche's words: "Truth" is therefore

\footnotetext{
${ }^{59}$ Nietzsche, The Will to Power, Aphorism 572.

${ }^{60}$ Ibid., Aphorism 800.

${ }^{61}$ Ibid., Aphorism 802.

${ }^{62}$ Ibid., A phorism 805.

${ }^{63}$ Ibid., A phorism 806.

${ }^{64}$ Ibid., A phorism 853, iv.

${ }^{65}$ Heidegger, Nietzsche, 217.

${ }^{66}$ Nietzsche, The Will to Power, Aphorism, 822.

${ }^{67}$ Ibid., Aphorism 517.
} 
not something there, that might be found or discovered - but something that must be created... It is a word for the will to power."${ }^{\prime 68}$

After describing how truth is the result of will to power, Nietzsche proceeds to reveal 'the absurdities' that come from this creation, amongst which is the false nature of values. Hence, "the value of the world lies in our interpretation, ${ }^{\prime \prime 9}$ and interpretation is, after all, how the will to power expresses itself in life. ${ }^{70}$ Man transforms the will to life present in his biological life into the will to truth. Or more accurately, in the creation of absolute truth and values. Christianity, according to Nietzsche, is another form of this absolute truth. The absolute inversion of this truth is nihilism, or "the belief that there is no truth at all."171 About this inversion, Nietzsche claims, "we have created a world that possesses values! Knowing this, we know, too that reverence for truth is already the consequence of an illusion.." ${ }^{\prime 2}$ The problem Nietzsche sees with both the affirmation and the denial of absolute truth, aside from the fact that he finds the first to be a lie, is that both weaken the will. ${ }^{73}$ Moreover, and particularly important in the context of eternal recurrence, when men adopt an existing or ready-made truth, they "corrupt for [themselves] the innocence of becoming," ${ }^{14}$ or the ability to become their own creation and to assert their own truth and their own morality.

\footnotetext{
${ }^{68}$ Nietzsche, The Will to Power, Aphorism 552.

${ }^{69}$ Ibid., Aphorism 552, 616.

${ }^{70}$ Ibid., A A horism 639.

${ }^{71}$ Ibid., Aphorism 598.

${ }^{72}$ Ibid., Aphorism 602.

${ }_{74}^{73}$ Ibid., A phorism 29, 136, 305.

${ }^{74}$ Ibid., Aphorism 552.
} 
This creative ability has further ramifications. In the context of eternal recurrence, creation is not a 'one time' creation, but a continuous and repetitive creative process. Nietzsche asserts that what distinguishes the artist from the laymen is that "the latter reach the high point of their susceptibility when they receive; the former when they give. ${ }^{\prime 75} \mathrm{He}$ illustrates this with a sexual metaphor: It is the same here as with the difference between the sexes: one ought not to demand of the artist, who gives, that he should become a woman - that he should receive.

Our aesthetics hitherto have become a woman's aesthetics to the extent that only the receivers of art have formulated their experience of "what is beautiful?"76

In other words, artists must build on previous artistic creations.

These quotes reveal how the notion of creation becomes a constant process of building on previous creation. In Beyond Good and Evil Nietzsche further clarifies this, stating "the ideal of the most high-spirited, alive, and world-affirming human being who has not only come to terms and learned to get along with whatever was and is, but who wants to have what was and is repeated all eternity, shouting insatiably da capo - not only to himself but the whole play and spectacle." ${ }^{\prime 77}$ The prospect of eternal recurrence encountered in biological life that disgusts Zarathustra (because it applied to the entire species) is remedied by introducing the will-to-create, which, in turn, prevents eternal recurrence from being adopted by all.

\footnotetext{
${ }^{75}$ Nietzsche, The Will to Power, Aphorism 811.

${ }^{76}$ Ibid.

${ }^{77}$ Ibid., The Gay Science, 56.
} 
Once Nietzsche outlines these conditions, he proceeds to merge artistic thought with historical action. This merger, he hopes, will transform both Western philosophy, and one's personal life. This ability to act onto history has been widely interpreted from the brute violence of the 'blond beast' to Heidegger's more thoughtful, but also radical, reading. According to Heidegger, Nietzsche's Zarathustra speaks of a transition towards a new spirit "redeemed from revenge" that "lies outside feeble neglect of things and avoidance of sacrifice, outside blind intervention and the will to action at any price. ${ }^{\prime 78}$ Hence, Nietzsche marks, according to Heidegger, a transition beyond good and evil, that returns us to the beginning of metaphysics.

\section{Freitod and deceptive freedom}

Nietzsche's approach to artistic creativity has powerful implications for one's life and, more importantly here, for one's death. It is to those that I now turn. Nietzsche's manner of directing artistic creativity towards one's own life is crucial to conceptualizing the fascination with, and the allurement to, choosing one's own death, which is the foundation for many right to die arguments. As mentioned previously, Nietzsche describes how artistic creativity can be oriented towards one's own life, and also how this creative ability culminates in a will for da capo, or repetition. In the context of eternal recurrence, artistic creativity is no longer directed towards art in general, or towards the creation of some 'new' metaphysical truth, but rather towards one's own life. In its most radical

\footnotetext{
${ }^{78}$ Heidegger, Nietzsche, 220.
} 
expression, it is also directed towards one's death. As Zarathustra teaches: "I command you my sort of death, voluntary death that comes to me because I wish it." ${ }^{179}$ Nietzsche's Zarathustra invites man to exert his creativity, in action in thought, and even more radically in death.

If freedom towards death is understood through Nietzsche's work, then the positive freedom implied in the right to die becomes sheer madness because by following Nietzsche's advice, man severs his ties not only to all preexisting norms and values, but to nature itself. To orchestrate one's death is to abandon any previous connection with death understood as necessity ordained by nature and to make death a matter of personal decision bound only to one's own will. This approach reveals the dark side of amor fati. The embrace of life, defined by affirmations without any boundaries that typifying amor fati, transforms itself into an embrace of death because it does not have the mechanism to prevent life from sliding into the abyss of its own destruction. Goethe's poem, Blessed Longing poetically illustrates this all-consuming celebration of life: "I celebrate what lives intenser: / Life that yearns for death-by-fire."

In fairness to Nietzsche he never articulated an explicit argument for the right to die, nor has he ever attempted to merge his thought with the liberal tradition. Nevertheless, as Hannah Arendt points out, there is an inherent danger in conceptualizing individuality in relation to creative ability. Arendt is particularly critical of applying man's creative ability to politics through metaphors of fabrication because they set in motion perpetual violence to the nature of humanity. She writes "the law of Nature or the law of History, if

\footnotetext{
${ }^{79}$ Nietzsche, Thus Spoke Zarathustra, 97.
} 
properly executed, is expected to produce mankind as its end product. ${ }^{\prime 80}$ In the case of the right to die, however, the scenario is darker because these metaphors of creation produce death as their final product.

The German Society for Humane Dying (DGHS) is a clear indication that Nietzsche's thought came to merge with the liberal concept of rights. DGHS was founded in the 1980s and facilitates suicide for the terminally ill. Interestingly on their forms, they did not use the German words Selbstmord, Selbsttotung, or Suizid, opting instead for the word Freitod. This word was invented by Nietzsche's sister by fusing the two words that originally made up the title for the chapter "Freitod," (i.e. Frei Tod - Free Death), in Thus Spoke Zarathustra. In this section Nietzsche writes: "free for death and free in death, one who solemnly says No when there is no longer time for Yes.. ${ }^{\prime \prime 1}$ It is beyond of the scope of this work to examine the affairs of DGHS, such as its recent political scandals, its loss in popularity and the minor alterations made to its practices. What is important to point out, however, is that the very language adopted by the right to die advocates in Germany can be traced back to Nietzsche's thought.

The DGHS's arguments, even if not yet the exact language, reflect those of English-speaking organizations mentioned earlier. Underlying their arguments for the right to die in the case of the terminally ill, is an implicit notion of freedom towards death. As Battin rightly observed, "the precise nature of the relationship between Freitod and assisted suicide may be difficult for Germans to capture in practice, and virtually impossible for English speakers to

${ }^{80}$ Hannah Arendt, The Origins of Totalitarianism (New York: Library of Congress Cataloging-in-Publication Data, 1996), 462.

${ }^{81}$ Nietzsche, Thus Spoke Zarathustra, 99. 
understand." ${ }^{82}$ Indeed, at least two of the greatest difficulties of this relation in pragmatic terms are: the implication that, for the right to die to become common practice, the state is expected to judge when one's life is no longer worthy of protection. Moreover, in the case of publicly funded health care, the right to die obliges the state to become actively involved in killing its citizens. The other difficulty is contained in the connotation of positive freedom within the liberal tradition of rights, implying a freedom towards one's greater potentiality. Within the context of the right to die, this becomes the morbid pursuit of one's death.

Despite the language of rights that Nietzsche himself sometimes uses, the kind of freedom he actually proposes is not positive freedom. Indeed, Nietzsche himself would not advocate government intervention because there is little in his thought that would lend support to any conventional authority, especially state authority. His conceptualization of freedom is actually rooted in the tradition of German Idealism and involves the radical assertion of a subject. It also involves what Heidegger called "the independence to stand within one's own essential law, ${ }^{\prime 83}$ or "freedom as self-determination in terms of one's own essential law." ${ }^{\prime 84}$ This is a concept, as mentioned earlier, more radical than Kant's notion of autonomy, that at least preserves one's ability to act according to universal reason.

Heidegger also attempts to address this element of radical subjectivity or subjective assertion of the "I," but strong elements of Idealism remain present in

\footnotetext{
${ }^{82}$ Battin, The Least Worst Death, 268.

${ }^{83}$ Heidegger, Schelling's Treatise on the essence of Human Freedom, 83.

${ }^{84}$ Ibid., 88.
} 
his thought. ${ }^{85}$ The manner in which one becomes resolute bears strong similarity to Nietzsche's eternal return. As Heidegger writes: "this holding-for-true, as a resolute holding-oneself-free for taking back, is authentic resoluteness which resolves to keep repeating itself. ${ }^{86}$ Regardless, Heidegger's magnum opus, Being and Time, could accommodate elements of Idealism because it was not bound by the liberal constraints of negative freedom.

\section{Concluding remarks}

The inclusion of the right to die in the liberal tradition of rights signals a radicalization of the Western understanding of freedom. It is true that modern technology has provided not only great cures and a better standard of living. But it has also prolonged dying. As such, it is common sensical to seriously engage the time and circumstances under which one's life may end. However, there is little reason why this debate could not still occur within the liberal tradition in which, as Hobbes maintained, "liberty rests in the silence of the law," and in which laws would provide a limitation on the part of the medical profession to force people on life support or to forbid them from purchasing lethal drugs.

This is not merely a matter of semantics, but rather reaches to the core of the liberal tradition, where laws, as Hobbes wrote, "determineth and bindeth to one of them" and "right consisteth in liberty to do." Laws denote a limitation on

${ }^{85}$ Christian Lotz, "Existential idealism? Fichte and Heidegger," Epoché 12 (Fall 2007): 109-135.

${ }^{86}$ Martin Heidegger, Being and Time, trans. John Macquarrie \& Edward Robinson (Oxford: Blackwell Publishers Ltd., 1962), 308. 
the part of the state to intervene in one's decision, whereas rights imply an invitation on the part of the state to intervene to bring about one's death.

Moreover, arguments for the creation of a right to die are not rooted in debates over what is right or wrong. Nor are they rooted in altruistic concerns about easing the burden of those caring for the old and suffering, for surely the burden of forcing people into killing their loved ones is far greater. Quite the contrary: arguments for the right to die often reveal a preoccupation with the perceptions of others. What is at stake, to phrase it bluntly, is not the right or wrong of practices such as euthanasia, but the desire to remove from it the negative connotations of $\sin$ and of wrongdoing and to replace these with positive, libratory, and even inviting undertones making the right to die appealing.

Further still, the arguments in favor of the right to die are not the direct product of nihilism, of which Schopenhauer provides the most radical example and which do not grant philosophical justifications for the inclusion of a right to die. Rather, the justification for the right to die rests on a radical understanding of freedom as self-legislation bound to nothing. It is a freedom understood as freedom from necessity and where death is further understood as the ultimate necessity. In other words, this understanding of freedom promotes an escape from death as necessity by generating the false impression that a human being is able to control death by ironically choosing death.

Finally, the radical understanding of freedom that lies behind right to die arguments can also provide the foundation on which further arguments for darker liberties can also be built in the future, and about which my imagination will refrain. 
Even though, as this chapter shows, the artistic creativity present in eternal recurrence has dark and dangerous implications for liberalism if taken to the extreme of Freitod, it has proven to be a powerful resource for Heidegger in Being and Time. Indeed, the concept of authentic resoluteness, "which resolves to keep repeating itself, ${ }^{\prime \prime 7}$ hinges on the same principle of repetition and radical freedom introduced by Nietzsche.

${ }^{87}$ Heidegger, Being and Time, 308. 


\section{Chapter 2. Suicide and Being-towards-Death}

Suicide is a peculiar word. It denotes an action. Yet, in English, it is a noun rather than a verb. The word 'suicide' is an English neologism coined by Sir Thomas Browne in the Seventeenth Century merging the Latin words sui, meaning himself, and caedes, meaning to kill. This word was subsequently adopted on mainland Europe, where, depending on the language, it generated various grammatical incoherencies. In French, for instance, the word suicide did not exist until the mid-eighteen century. Even to this day, it is used in the pleonastic form se suicider. This etymology is itself emblematic of the ambiguity surrounding the action of killing oneself.

The purpose of this chapter is to clarify some of the vagueness surrounding suicide. The first part provides a brief sociological overview of suicide based on Emile Durkheim's seminal work Suicide: A Study in Sociology. I opt for this approach because Durkheim's main categories of suicide remain mutatis mutandi valid in the Twentieth Century. They also simultaneously provide the flexibility needed to conceptualize modern forms of, and perceptions about, suicide. I include brief historical observations, but I opt against a predominantly historical approach because the history of suicide is not conducive to a purely chronological approach. I conclude by analyzing the more recent trend among psychiatrists of rationalizing suicide, culminating in attempts to use the idea of suicide therapeutically to deter patients from committing this act. 
The second part of this chapter focuses on Martin Heidegger's thought. Here, I show how, that despite the intense preoccupation with death, Heidegger's thought cannot be used, to support suicide nor should be used therapeutically to prevent suicide. I do so by examining the interplay between Dasein's Being-towards-death and care (Sorge) and focus on two possible translations of Dasein: 'Being-Open' and 'Being-Here.' I argue that, while 'BeingOpen' could in theory be used to support suicide, the connotation of 'Being-Here' or being 'thrown into the world' necessarily opposes it in practice. Finally, I conclude that using the possibility of one's death in thought to gain a greater appreciation for one's life in this world, can have disastrous implications if the idea is removed from its philosophical context and used merely as a rhetorical exercise to persuade against suicide.

\section{Categories of suicide}

Suicide is the most personal of acts and this makes it difficult to isolate the causes that lead people to kill themselves. Luckily, Emile Durkheim's seminal work on the topic provides a good point of reference for discussing suicide. I begin by examining the four major types of suicides identified by Durkheim, and conclude by outlining some of their relevance to current debates.

Durkheim defines egoistic suicide as suicide that is predominantly associated with the loss of both traditional beliefs and a sense of belonging, be it belonging to a religious, domestic, or political community. This loss is most prevalent in Protestant Europe, and Durkheim argues, it can be traced back to 
the "spirit of free inquiry that animates this religion." This spirit of free inquiry, though not Protestantism per se, corrodes, according to Durkheim, traditional beliefs. This, in turn, triggers reflection. Reflection emerges from the spiritual void left over from the dismantling of ideas that previously guided conduct. It "asserts its rights against public opinion only when the letter looses strength." This freedom for reflection often leads people to search for meaning and order in universities, as evidence by a higher university enrollment amongst Protestant Europeans.

Durkheim is careful not to associate learning with suicide. For, as he writes: "far from knowledge being the source of the evil, it is its remedy, and the only remedy we have. Once established beliefs have been carried away by the current of affairs, they cannot be artificially reestablished." ${ }^{3}$ To bolster his argument, he shows that high Jewish enrollment in Universities is inversely correlated with suicides in the Jewish Community. Jewish people registered the lowest suicide rates in Europe, despite the Jewish Bible being vague about the afterlife and prescribing no law forbidding suicide. He concludes, that "knowledge is not sought as a means to destroy accepted opinions but because their destruction has commenced." ${ }^{4}$ Durkheim's remarks resonate with Socrates, who amidst the moral and political destruction during the Peloponnesian War, 'turned away' from the poets that represented the traditional way of life, in the pursuit of a different order.

\footnotetext{
${ }^{1}$ Emile Durkheim, Suicide: A Study in Sociology (Glencoe: The Free Press, 1951), 158.

${ }^{2}$ Ibid., 158-159.

${ }^{3}$ Ibid., 169.

${ }^{4}$ Ibid.
} 
Interestingly, Durkheim argues that the causes of suicide also reflect the type of suicide one opts for. Thus, people who commit egoist suicide adopt a calm and melancholic, though not unpleasant, attitude towards life during their last moments. Their actual suicide is well planed out and usually effective.

Anomic suicide correlates with economic and social crises. These include all disturbances of collective order. Whenever a disturbance in equilibrium occurs, be it a sudden growth or catastrophe requiring serious readjustments of the social order, men are more inclined towards anomic suicide. ${ }^{5}$ This may explain why people becoming rich overnight, either from an unexpected inheritance or by winning the lottery, often commit suicide rather than enjoying their new-found wealth. Thus, even though a disturbance actually generates greater comfort, it can still account for anomic suicide.

According to Durkheim, this occurs because society fails to restrain man's unlimited desires through a collective order. ${ }^{6}$ When society is able to restrain man's needs, an equilibrium between possibilities and limitations is achieved and anomic suicide is prevented. If society fails, and social restraints become weak or vanish all together, then an individual will find it difficult to adapt and to find the necessary authority in society to justify his change in social status.

A change in one's social status is more difficult to bear in cases of economic growth because the increase in an individual's possibilities, coupled with a decrease in social restraints through norms and values, gives people the sense that there are unlimited possibilities. "The less limited one feels,"

\footnotetext{
${ }^{5}$ Durkheim, Suicide, 246.

${ }^{6}$ Ibid., 247.
} 
Durkheim writes", "the more intolerable all limitation appears." ${ }^{\prime 7}$ This is arguably the most intriguing of the four types of suicide because Durkheim insists it is the most prevalent in modern societies, followed by egoistic suicide.

Altruistic suicide, another form of suicide identified by Durkheim, occurs when explicit or implicit societal norms create the perception among a community that people must sacrifice their lives. While too little integration in society can lead one to commit suicide, too much integration, or insufficient individuation, can have the same effect. The old Hindu custom, according to which wives are expected to kill themselves upon their husbands' death, is one such example. This sort of suicide involves one not killing himself or herself out of self-determination, but rather out of duty. Failing to honor this duty can result in being dishonored and even punished by his or her community. Society therefore plays the opposite role in altruistic suicide, compared to egoistic suicide, because it encourages the former kind of suicide while forbidding the latter.

Durkheim also includes the death of martyrs as an example of altruistic suicide. In such cases, he writes: "we actually see the individual....seek to strip himself of his personal being in order to be engulfed in something which he regards as his true essence. ${ }^{\prime \prime}$ Whereas, in the case of egoistic suicide, the individual feels useless and purposeless, individuals committing altruistic suicide, have a goal that is "outside of this life, which henceforth seems merely an obstacle to him. ${ }^{\prime \prime}$

\footnotetext{
${ }^{7}$ Durkheim, Suicide, 254.

${ }^{8}$ Ibid., 225.

${ }^{9}$ Ibid.
} 
The same cause is also attributed to high suicide rates amongst soldiers. The altruistic sprit, without which the army is inconceivable, also makes the solider willing to commit suicide for futile reasons, such as an unjust punishment, a delay in promotion, a flush of momentary jealousy, or even because of previous suicides he has witnessed among peers. In the absence of an overarching cause for which the army has physiologically trained the solider to die, the solider is more likely to adopt a cause of his own, however trivial such a cause might be.

Durkheim concludes that, contrary to egoistic suicide, altruistic suicide resembles motives and actions that are honored and respected in society. Consequently, people often refuse to consider it self-destruction. ${ }^{10}$ People committing altruistic suicide demonstrate a sense of enthusiasm and even passion when carrying out the act while, the community often regards the act as honorable. Durkheim uses Cato's famous suicide as an example of altruistic suicide. ${ }^{11}$

The fourth type of suicide is fatalistic suicide. Durkheim mentions it only in a footnote as being the opposite of altruistic suicide. He maintains that it is of historical, but not contemporary, importance. It is a form of suicide that occurs under conditions of physical or moral despotism, such as, for instance, in societies tolerating slavery. It is also accurate to classify as fatalistic, the suicide of people forced to live in dictatorial regimes. There are numerous examples, including the well-known case of Jan Palach in former Czechoslovakia and numerous others in the former Eastern Block. To this list of fatalistic suicides can

${ }^{10}$ Durkheim, Suicide, 239.

${ }^{11}$ Tbid., 283. 
also be added the monks setting themselves on fire in Burma, and women committing suicide in Iran. ${ }^{12}$

Durkheim categorizes suicides based primarily on the isolated external factors determining their occurrence. He does acknowledge, however, that one may observe a combination of these factors when analyzing individual forms of suicide. The combination of societal factors may increase the likelihood of individuals committing suicide. A combination of egoistic and anomic suicide is typified by an irritated disgust with life. This is evidenced in Seneca's claim: "Is it my fault if I everywhere find limits, if everything once experienced has no value for me? $?^{\prime 13}$

Moreover, even opposites such as egoism and altruism can become combined under certain circumstances. This occurs when a group is alienated from society, while the people forming that group are themselves connected to nothing real and "find satisfaction only in creating out of whole cloth some ideal reality to play this role. ${ }^{14}$ Under these circumstances, people live as egoists vis-àvis the real world and as altruists with regards to the group they have formed. Groups founded by Aum Shinrikyo in Japan and Jim Jones in America are terrible examples that correspond to this combination of altruistic and egoistic suicide as are some of the fundamentalist Islamic terrorist cells.

I will return to these broad categories later. But for now, it is important to emphasize that Durkheim's admission that the statistical approach he uses to arrive at these broad categories "leaves the question of free will much more

${ }^{12}$ Akbar Aliverdinia, "Women's Fatalistic Suicide in Iran A Partial Test of Durkheim in an Islamic Republic," Violence Against Women 15 (March 2009): 307320.

${ }^{13}$ Durkheim, Suicide, 287.

${ }^{14}$ Ibid., 289. 
untouched than if one made the individual the source of social phenomena. ${ }^{15} \mathrm{I}$ do not wish to engage the larger issues of statistical use, part of which I will be discussing in greater detail in Chapter 4. Instead, I must point out some significant discrepancies. First, despite Durkheim's commitment to understanding the facts about suicide objectively, his study does not end at observing or at identifying patterns according to which people kill themselves. Instead, his study concludes by providing specific recommendations for preventing suicide. In other words, Durkheim is operating on the underlying assumption that suicide is wrong and that it ought to always be prevented.

The second inconsistency in Durkheim's study is that even though suicide is a personal act, arguably the most personal of acts, Durkheim overlooks the individual's responsibility in opting to commit suicide and attributes it instead to various factors in society. This approach would come to have a dramatic impact on the future direction of sociology because it generated the belief that society alone is responsible for an individual's decision. Finally, his study is unable to account for the many immeasurable factors prompting suicide, such as, for instance, a momentary desire to end one's life followed by swift and fatal action. However, Durkheim provides an excellent foundation for conceptualizing suicide in this study.

\section{Brief history of suicide}

${ }^{15}$ Durkheim, Suicide, 320, note 20. 
Durkheim's study may examine the relationship between the individual and society, but it fails to consider differences in social status. According to Georges Minois, though it is true that both the poor and the rich kill themselves, their methods, especially in Medieval Europe, were different. The noblemen's suicides often reflected altruistic forms of suicide. Noblemen usually accepted suicidal missions in battle or killed themselves out of love. These types of deaths carried an air of respectability. ${ }^{16}$ The poor, meanwhile, committed suicide often in secret and opted for more rudimentary methods. Men were more likely to kill themselves by hanging, while women by drowning. But because these latter two types of suicides lacked a social character, they also lacked respectability and they were thus portrayed as acts of despair. The suicidal act of the poor, therefore, at least according to Minois' description, would qualify as egoistic suicides while the noble are akin to altruistic suicide.

Since egoistic suicide was associated with despair, there was often the popular belief that the devil was involved, or that the individual was insane. The older Roman tradition in which a free man could reason in such a way as to bring about his own death, was eventually lost during Medieval Europe and suicide became regarded as irrational: against nature and God himself, and a symptom of insanity or satanic instigation. ${ }^{17}$

Despite societal changes in Europe over time in the way Europeans perceived suicide, Westerners still maintain largely negative attitudes towards suicide. And, these negative attitudes have old historical roots. In Medieval Europe, suicide was considered the work of the devil, while the act itself was

${ }^{16}$ George Minois, History of Suicide: Voluntary Death in Western Culture, trans. Lydia G. Cochrane (Baltimore: The John Hopkins University Press, 1999), 16. ${ }^{17}$ Ibid., 41. 
both a religious and a civil crime punishable by both the clergy and the state. The Church refused to bury those committing suicide in the city's cemetery and the state deprived their families of their inheritance. During the Enlightenment, this moral responsibility became diffused in society and the suicidal "criminal was, in part, transformed into a victim": a victim of his own physiology, a victim of the misfortunes of those around him, or a victim of social and political circumstances. ${ }^{18}$ This trend continued in Europe and, by the Eighteen Century, the "suicide rate reflected the health of the entire social group." ${ }^{\prime 9}$ This period saw the beginning of the trend to use suicide rates as indicators for the health of a population, as evidenced in Durkheim's work.

The Nineteenth Century continued to see emphasis on collective guilt, especially as statistical measurement became increasingly utilized to monitor suicides rates. Collective guilt, according to Minois, had the effect of making the issue of suicide taboo. As this happened, the negative connotations of suicide were no longer challenged. Thus, to the original negative perceptions of suicide were added new ones, generating an environment where suicide was either an offense to God, a moral depravity indicative of a lack of respect for traditional values, a mental weakness, a symptom of liberalism, anarchy, or materialism, ${ }^{20}$ or all of these combined.

The more individual suicides became stigmatized in society, the more the act became discussed in the abstract: most famously by philosophers Arthur Schopenhauer and Søren Kierkegaard. ${ }^{21}$ Today we continue to regard suicide as a

\footnotetext{
${ }^{18}$ Minois, History of Suicide, 301.

${ }^{19}$ Ibid.

${ }^{20}$ Ibid., 320.

${ }^{21}$ Ibid., 321.
} 
sign of moral decay and to treat it as taboo. But this is slowly changing and Minois' own historical overview of suicide is itself proof that scholars are beginning to view suicide more positively. This is part of a growing trend of rationalizing suicide, to which I now turn.

\section{Rationalizing suicide}

In Chapter 1, I examined the implications of right to die arguments based on autonomy and how these arguments reveal a fascination with freedom rather than a commitment to justice. I also discussed the dangers of invoking principles of positive freedom to rationalize dying and death because these imply, among other things, an obligation on the part of the state to ensure citizens are guaranteed this right. In this chapter, I include Thomas Szasz's arguments for suicide, centered on principles of non-intervention. Though, on the surface, his arguments resemble the arguments for the right to die, Szasz actually argues against this right. Moreover, Szasz anchors his argument for suicide in the liberal tradition and does so without invoking the culture of rights. He maintains instead that such a debate only obfuscates the issue.

Szasz argues that suicide is not necessarily a mental problem. And, further he continues, believing it to be so reinforces the false perception that our society should depend on physicians, and especially psychiatrists, to prevent suicide. Yet, this reliance would, in turn, endow physicians with an unprecedented 
power in society. ${ }^{22}$ A psychiatrist himself, Szasz argues that this increased reliance on psychiatry and on prescription drugs to deal with suicide has encouraged the practice of physician-assisted suicide.

To show that suicide is not a mental problem, he uses the example of psychiatrists who have been unable 'to cure' it despite having institutionalized draconian methods throughout history. For instance, in 1959, the American Handbook of Psychiatry endorsed lobotomy for suicidal patients. In 1974, it replaced it, with electroshock treatment, designed to destroy the patient's will to commit suicide. The Handbook has since been updated and has now replaced these with prescription drugs. ${ }^{23}$ In short, despite the efforts of psychiatrists to prevent suicide in society, people still kill themselves. And, no single treatment has proven effective enough to 'treat' the desire some people have to commit suicide despite repeated attempts by psychiatrists to find the perfect cure.

Ironically, psychiatrists entrusted with 'curing' suicide are themselves three times more likely to commit suicide then the average citizens. ${ }^{24}$ Oddly enough, despite their poor record of treating suicide, psychiatrists are still becoming increasingly powerful in our present-day society. Currently, they hold the power to pardon homicidal offenders on grounds of insanity. ${ }^{25}$ More recently, in some countries, they can even prescribe lethal drugs and administer these drugs, effectively granting them a license to kill.

Szasz's argument is not for or against suicide, but rather for excluding the state, be it represented by physicians or psychiatrists, from getting involved in

${ }^{22}$ Thomas Szasz, Fatal Freedom: the ethics and politics of suicide (Wesport: Praeger Publishers, 1999), ix.

${ }^{23}$ Szasz, Fatal Freedom, 57.

${ }^{24}$ Ibid., 61.

${ }^{25}$ Ibid., 36. 
the highly personal decision to commit suicide. He does not advocate for a right to die; rather, his argument reflects the Hobbesian notion of freedom as "freedom in the silence of the law." He stands against the establishment of what he calls "The Therapeutic State." ${ }^{\prime 6}$ Szasz's work has been extremely influential in questioning the legitimacy of psychiatry, and his views on suicide have unleashed a vast debate about the need to allow for the possibility that suicide may also be a rational action. Though these arguments for conceptualizing suicide as a rational act represent a growing trend, there is, of course, significant opposition among scholars and the public at large.

Part of this growing trend to rationalize suicide is also evidenced by guidelines put forth by psychiatrists for establishing clear criteria for rational suicide. Some of such guidelines are the following four basic criteria: 1) the patient is experiencing an unremittingly hopeless condition; 2) the decision to act is an informed one; 3) the individual is not impaired to the extent that he can no longer make an informed decision; and 4) he is not coerced into committing suicide. Or, simply put, it may be defined as "a well-thought-out decision by a rational individual who is mentally competent and who is capable of reasoning and choosing the best alternative among the many available. ${ }^{27}$ Naturally, both the criteria and the definition are subject to interpretation and generate animated debates.

These four criteria are of particular interest here because they resonate with Durkheim's conceptualizations of egoistic and atomic suicides. These criteria legitimize suicide based on changes in one's physical and mental

${ }^{26}$ Szasz, Fatal Freedom, 34.

${ }^{27}$ Dolores Gallagher-Thomson and Nancy J. Osgood, "Suicide in Later Life" Behavior Therapy, 28 (1997): 29. 
conditions: changes so drastic that they render the patient as 'hopeless.' These criteria also legitimize suicide in cases where the radical deterioration of a patient's health offsets the equilibrium between his possibilities and his limitations.

These criteria resonate with the causes that typify, according to Durkheim, atomic suicide. They also legitimize egoistic suicide because they focus solely on the individual's choices independent of other cultural taboos that may deter the individual from committing suicide. Yet these criteria do not rationalize suicide out of duty, which, according to Durkheim, typifies altruistic suicide, nor reactions to despotism, that typify fatalistic suicide. In sum, modern criteria for rationalizing suicide correspond to the most common forms of suicides in the Western world, while fatalistic and altruistic suicide, or combinations of these categories, remain irrational forms of suicide.

Adding to the list of egoistic and altruistic suicides likely to be considered rational in the future are the suicides of the elderly. Indeed suicide varies significantly according to demographics. This in part is due to the fact that advancements in biotechnology, despite their positive character, have had the negative effect of prolonging the dying process amongst the elderly. Yet, not all demographic groups are equally prone to committing suicide under these circumstances. Caucasian males, for instance, have experienced the highest suicide rates in the last twenty years, followed by both Caucasian and Asians women. These suicide also have elements of anomic because they involve a change in physical well-being not so much linked to changes in their economic status but to the physical degradation that accompanies a prolonged dying process made possible by modern medical technology. 
However, these attempts to rationalize suicide still aim at preventing suicide by understanding the reasons why people kill themselves. Like Durkheim, many psychiatrists and physicians operate on the premise that, once the causes of suicide are understood, measures to alleviate them can be taken and men and women can be appropriately deterred from committing suicide. However, as I show in the following account, once suicide is understood as a rational act, psychiatrists can use it as a thought experiment to ironically prevent its occurrence.

Some psychiatrists have gone beyond simply rationalizing suicide to using it as a therapeutic tool. To put it in Heidegger's words, this use of rational suicide is based on the belief that the thought of suicide can open possibilities towards life and away from one's death. In his article "Using Rational Suicide as an Intervention to Prevent Irrational Suicide," James Werth resonates more with Heidegger's thought than he is probably aware. As the title suggests, Werth's article shows that acknowledging rational suicide is a good starting point for diverting a patient's desire to commit suicide. He argues that, if a "person feels as if she or he has control over a situation in which she or he formally felt helpless, the urge to suicide will be decreased. ${ }^{28} \mathrm{He}$ demonstrates this by pointing to a study that suggests $40 \%$ patients prescribed lethal medication did not use it because "knowing that something was available to them, and will remain available, reduced the incentive to seize it." ${ }^{29}$ Werth relies on his experience as a psychiatrist to describe how he used rational suicide as a starting point for deterring irrational suicide. In this manner, he was able to help a

${ }^{28}$ James L. Werth, "Using Rational Suicide as Intervention to Prevent Irrational Suicide," Crisis, 19 (1998), 186.

${ }^{29}$ Ibid., 187. 
pregnant teenager who felt that suicide was her only option. He describes his approach as follows:

I did several things. I took out a sheet of paper and began to widen her blinders. I said something like, "Now, let's see: you could have an abortion here locally." She responded, "I couldn't do that....I continued,...."You could bring the baby to term and keep the baby." "I couldn't do that." "You could have the baby and adopt it out." Further options were similarly discussed. When I said "You can always commit suicide, but there is obviously no need to do that today," there was no response. "Now," I said "let's look at this list and rank them in order of your preference, keeping in mind that none of them is optimal."

My nonjudgmental approach in making this list already had a calming effect on her....She actually rank-ordered the list, commenting negatively on each of them. What was of critical importance was that suicide was no longer ranked first or second. ${ }^{\prime \prime 30}$

Werth's use of rational suicide signals a radical transition away from a conceptualization of suicide as the work of the devil, a symptom of mental illness, or even as a mere rational act. His approach represents a transition towards the novel view that the thought of suicide can lead towards future possibilities.

There are, of course, other 'dark' and more dangerous possibilities emerging from Werth's approach and which he does not acknowledge. For

\footnotetext{
${ }^{30}$ Werth, "Using Rational Suicide as Intervention to Prevent Irrational Suicide," 189.
} 
instance, one wonders whether his technique of considering rational suicide as a legitimate option for preventing it is suitable for treating depressed patients. Could it help young people overcome difficult teenage years by suggesting they contemplate suicide? In other words, are there any safe-guards that can prevent people who are already contemplating suicide from actually interpreting this method as encouragement to commit suicide? These examples point to the danger of seeing suicide as more than just the act of killing oneself, but as a confrontation with one's own death that can open up possibilities for life.

\section{The Meaning of Dasein}

By examining Martin Heidegger's concept of Dasein and his insights on death and mortality a more thorough comprehension of this approach to rational suicide - meant to open up possibilities - is attained. Of all the terms Heidegger makes up, arguably, Dasein is the most opaque. Heidegger defines Dasein in Being and Time as an entity created for the purpose of working out the question of Being. In his words:

Thus to work out the question of being adequately, we must make an entity - the inquirer - transparent in his own Being. The very asking of this question is an entity's mode of Being; and as such it gets its essential character from what is inquired about - namely Being. This entity which each of us is himself and which includes inquiring as one of the possibilities of its Being, we shall denote by the term "Dasein."

\footnotetext{
${ }^{31}$ Heidegger, Being and Time, 7.
} 
To complicate matters further, Dasein sometimes indicates a singular and other times a plural. Heidegger also uses the plural form of Dasein to indicate that the self cannot be separated from its world. In this manner, Heidegger also distances his thought from the radical subjectivity of German Idealism and from the 'freefloating I' that typifies this tradition.

In the next chapter I deal with Dasein within the context of empathy and will focus on Dasein in its plural form. Here, I discuss Dasein in its singular form because, the focus is Dasein's encounter with its death and this encounter can only be one's own. Dasein, after all, can only face its own death because nobody can take one's death away from it. As Heidegger explains:

Dying is something that every Dasein itself must take upon itself at the time. By its very essence, death is in every case mine, in so far as it 'is' at all. And indeed death signifies a peculiar possibility-of-Being in which the very Being of one's own Dasein is an issue. In dying, it is shown that mineness and existence are ontologically constitutive for death. $^{32}$

Though it is true that Dasein can occasionally become lost amongst 'the they's3 while Being-in-the-world, once Dasein confronts its own death Dasein as an entity becomes necessarily singular.

Even in this singular form, Dasein can still have numerous meanings. Some of these meanings are discussed here using Daniel Dahlstrom's explanations as a guide. Dahlstrom traces Da-sein's introduction to German philosophical jargon back to the early Eighteen Century and attributes it to Wolff

${ }^{32}$ Heidegger, Being and Time, 240.

${ }^{33}$ For a more thorough discussion of 'the they' or Das Man please see Chapter 3. 
and Gottsched. These thinkers used it to replace the Latin "Existenz." 34 Yet, Heidegger also uses existenz periodically in Being and Time and thus a different translation is required.

Dasein is constituted from the words: $d a$ and sein. The word da is an adverb of both time and place, and, in conjunction with Sein, generates the connotation of a being of space and time..$^{35}$ And, though $d a$ is most often used to indicate a place rather than a time, this is further complicated by the fact that it can indicate both a 'here' and a 'there. ${ }^{36}$ Being-here or Being-there would both be viable ways of translating Dasein. They both generate a sense that Dasein is contained within a location and also, on some level, removed from itself, as an "always already outside-itself" or being-in-the-world. ${ }^{37}$ Yet, since 'Being-there' carries an additional connotation of distance, it risks denoting the theme of being as not of immediate and pressing concern. 'Being-here' therefore appears to be a more accurate translation.

This translation is still limited because it does not account for other possibilities implicit in the term Dasein. As, Heidegger maintains, the proper way to understand $d a$ in the context of Sein is as disclosedness. However, this term is already used in Heideggerian nomenclature to translate Erschlossenheit. One way to avoid confusion is to interpret the term as meaning 'openness' (resembling 'disclosedness') while maintaining a sense of spatiality present in $d a$. Dahlstrom, himself opted to translate Dasein as 'Being-here' with the necessary qualification that the term must be understood in conjunction with disclosedness. Dahlstrom

${ }^{34}$ Daniel Dahlstrom, Heidegger's Concept of Truth (Cambridge: Cambridge University Press, 2001), xxiii.

${ }^{35}$ Ibid., xxiv.

${ }^{36}$ Tbid.

${ }^{37}$ Ibid. 
writes: "To be-here is to disclose and to disclose is to be-here." ${ }^{38}$ This clarification is necessary here because 'Being-here' no longer contains the connotation of disclosedness that being-open did.

In this chapter I adopt both translations and I conceptualize 'Being-here' and 'Being-open' as integral parts of Dasein (like two sides of the same coin). The difference between them, used in this context, is that 'Being-here' characterizes Dasein's existence in the world, or Being-in-the-world, while 'Being-open' characterizes Dasein's potentiality-for-Being which is preceded by Dasein's Beingtowards-death.

\section{Dasein and Being-towards-death}

Hamlet's famous rhetorical question "To be or not to be?" pertains to action rather than thought. "Taking arms against a sea of troubles" implies a clear decision between life and death and it is not exactly in the same vain as thought. Had it been a philosophical question, Hamlet would have needed to postulate not his own death, but non-Being. There is, of course, a close kinship between these but this kinship is of a more recent vintage.

Socrates also argued that philosophy can teach one to be courageous in the face of the unknown, and thus, by extension, also in the face of one's own death, which is the final unknown. His own courage to face death was forged in a life dedicated to the pursuit of truth; and not the other way around. Encountering the possibility of one's own death in thought was not sufficient to

${ }^{38}$ Dahlstrom, Heidegger's Concept of Truth, xxv. 
make one courageous and did not prompt one to pursue truth. According to Plato, it is only after one engages with the possibility of Being that one can also contemplate its denial, or non-Being.

Even more striking, the contemplation of non-Being actually serves to assert Being by denying it. ${ }^{39}$ This is because non-Being can only be expressed in opposition to Being. Thus, by postulating, for instance, the non-existence of a pen, I already assert its existence in thought as the possibility of a pen, albeit only at the level of an idea.

Heidegger reverses the order entirely and attributes more importance to one's confrontation with the possibility of his death. While the Socratic pursuit of philosophical wisdom grants man courage to face the unknown, death being the greatest of unknowns, in Heideggerian thought, the confrontation with the possibility of one's death grants man the courage to think about Being. Thus, according to Heidegger, the contemplation of death opens up possibilities that can surprisingly enough, lead back to the contemplation of Being.

Heidegger maintains that one can find meaning for one's life after he contemplates his own death. On this premise, Heidegger builds a link between death and Being. However, the contemplation of one's death and the possibility towards Being that this contemplation opens up, bears no relation to the physical act of bringing about one's own death, or of committing suicide. Despite this, Heidegger's thought can still help us understand the current appeal to rational suicide. The conceptualization of suicide as both rational and as containing possibilities for life hinges on the broad meanings Heidegger attributes to Dasein.

\footnotetext{
${ }^{39}$ Plato, Sophist, trans. Benjamin Jowett (New York: Quiet Vision Publishing, 2004).
} 
Heidegger's approach to death was revolutionary. John Macquarie even wonders if the actual contemplation of one's death can be interpreted as the beginning of a new form of nihilism. ${ }^{40}$ Richard Kroner, meanwhile vividly describes the impact Heidegger's novel approach to the role of death in philosophy has had on his generation:

What was most fascinating and startling to me was not so much his metaphysical conception of Being, but rather his thoughts about death and mortality. These thoughts seemed to be in the very centre of his whole discussion. When I was a student, the Germans talked and wrote much about "philosophy of life", which Nietzsche especially had popularized, and it had been widely accepted in non-academic literary circles. Our university professors despised and severely criticized such a popular philosophy, telling us that it had no scientific value but merely stirred the emotions, and that a serious analysis could easily refute it. Heidegger, however, had transformed this philosophy of life into a philosophy of death and had furnished it with the solid defense of a critical method, thus giving it academic respectability. In this new attire, the formerly rejected philosophy of life demanded the greatest attention and the most careful study. ${ }^{41}$

Heidegger's transformation of Nietzsche's works from a philosophy of life to a 'philosophy of death' continues to have an unsettling effect, despite the fact that a similar element of euphoric unbound freedom is present in both. While for Nietzsche, this freedom is expressed in a Dionysian affirmation of life that can

${ }^{40}$ John Macquarrie, Heidegger and Christianity; The Hensley Henson Lectures 19931994 (New York: The Continuum Publishing Company, 1994), 33.

${ }^{41}$ Heidegger, Being and Time, 33. 
even engulf death, for Heidegger, this freedom can be experienced only after one comforts the possibility of his death in the search for authenticity.

Heidegger achieves this dramatic climax of freedom in death, or, more accurately phrased, freedom 'after death,' on this side of the grave by contrasting it with Dasein's condition of being-in-the-world. In the world, Dasein's existence is inauthentic: "Dasein is essentially falling, its state of Being is such that it is in 'untruth.'"142 Contributing to this fallen state are 'the they,' amongst whom Dasein necessarily lives. 'The they' often stifle Dasein's possibility towards Being, as will be discussed in the next chapter on euthanasia. However, even though Dasein is 'fallen,' it still has the potential to become authentic or open provided it faces its anxiety (Angst) about death.

Dasein must first encounter its anxiety when it "finds itself face to face with the "nothing' of the possible impossibility of its existence,"43 or the possibility of its own non-existence, before it can become authentic and relate to others authentically. Had Heidegger's insight ended here, his thought would have been more accurately called necrosophia rather than philosophy. This all the more so since death occupies a central part of Being and Time, while love (which incidentally is not even mentioned in Being and Time), or desire (in its broader sense) play a more minor role in his work. Therefore, with regards to the contemplation of Being, Heidegger replaces the erotic pursuit towards Being that had once been the mark of a philosopher, according to Plato, with an encounter of one's own death.

${ }^{42}$ Heidegger, Being and Time, 264.
${ }^{43}$ Ibid., 266. 
This begs the question: 'Is being aware of one's own death (or mortality) the main purpose for being?' Indeed, Heidegger also asks rhetorically "Does Being-in-the-world have a higher instance for its potentiality-for-Being than its own death?" ${ }^{\prime 4}$ As Heidegger argues Being and Time, this higher instance consists of care, or, Dasein's ability to develop an authentic relation with others after facing the possibility of his own death.

Facing one's own death opens up numerous possibilities for Dasein. Among those are: authentic being with others rooted in care, which will be discussed in the third chapter in relation to euthanasia; authentic temporality, discussed in the final chapter in relation to immortality; and, arguably, even authentic freedom as absence of causality. ${ }^{45}$ Thus, by translating Dasein as 'Being-

${ }^{44}$ Heidegger, Being and Time, 313.

${ }^{45}$ Dasein's possibility towards freedom from causality is not discussed in Being and Time. However, considering that Heidegger did not complete this work, and that the first section of the second part which Heidegger intended to publish reads "Kant's doctrine of schematism and time, as a preliminary stage in a problematic of time" (Being and Time, 40), it is possible to interpret Heidegger's later work on Kant as a continuation of Being and Time. This all the more so since The Essence of Human Freedom outlines the relation between time, causality and freedom in Kant's philosophy. This study also contains one of Heidegger's boldest claims about freedom in relation to Being. This relation emerges from Heidegger's disagreement with Kant who conceptualized freedom as the product of a universe typified by some order and even laws of causality.

Heidegger argues that freedom is not a possessive quality of man. Thus, according to Heidegger the statement - 'This man has freedom.'- is false. Instead, Heidegger maintains, "man is at best the property of freedom."(The Essence of Human Freedom, 9) Consequently, "freedom must itself, in its essence, be more primordial than man. Man is only an administrator of freedom ... Human freedom now no longer means freedom as a property of man, but man as a possibility of freedom. (94)

Heidegger goes still further and argues that causality is itself the product of freedom. In Heidegger's own words: "causality, movement, and being as such, are grounded in freedom." (94) Thus, Heidegger proposes a repositioning of freedom so that freedom precedes being and time and takes its place in the history of philosophy as the leading question of metaphysics. Again, in his own words: "the problem of freedom is not build into the leading and fundamental problems of philosophy, but, on the contrary, the leading question of metaphysics is grounded in 
open,' the emphasis is on the possibilities contained by Dasein rather than its actuality. There are indeed many references to possibility in relation to Dasein. Heidegger writes for instance: "possibility as an existentialle is the most primordial and ultimately positive way in which Dasein is characterized ontologically." ${ }^{146} \mathrm{He}$ also writes that "Being-possible, moreover, Dasein is never anything less; that is to say, it is existentially that which, in its potentiality-forBeing, it is not yet." ${ }^{\prime \prime 7}$ It is also important to recall Heidegger's actual definition of Dasein as the entity "which includes inquiring as one of the possibilities of its Being. ${ }^{\prime 48}$ Combined, these references to possibility generate an alluring belief that once one faces his death, he can draw from it grand new possibilities for life. This sense of allurement is amplified by the fact that Heidegger retains an aura of mystery around what these possibilities actually entail.

These possibilities are not all solitary pursuits. Indeed, differently from the German Idealist tradition, Dasein is also able to live authentically with others and develop relations based on care. ${ }^{49}$ Care, for Heidegger, is "the most primordial and basic existential truth, for which the problematic and fundamental ontology strives in preparing for the question of Being in general, is the disclosedness of the meaning of the Being of care. ${ }^{150}$ Care is what makes Dasein grounded in the world and also connected to others. Simply put, through care,

the question concerning the essence of freedom." (94) Yet, a universe typified by freedom rather than causality can also have radical implications for politics. It can unleash limit-less possibilities.

${ }^{46}$ Heidegger, Being and Time, 143-4.

${ }^{47}$ Tbid.

${ }^{48}$ Ibid., 7

${ }^{49}$ Chapter 3 discusses Care a more detail in relations to 'others.'

${ }^{50}$ Heidegger, Being and Time, 316. 
Heidegger is able to root Dasein into this world and prevent it from becoming a 'free-floating I."

Heidegger also illustrates the importance of care through a famous Roman legend of Care who is a minor Roman goddess. Care, according to the legend, formed man out of clay. When the gods came to discus the proper ownership of this new creature they agreed on the following: "Since you, Jupiter, have given it spirit, you shall receive that sprit at its death; and since you, Earth, have given its body, you shall receive its body. But since 'Care' first shaped this creature, she shall possess it as long as it lives." ${ }^{151}$ Thus, once man faces his own finitude he is also able to care for others and for his world.

\section{The impossibility of suicide: Thrown in the world}

Even though Heidegger discusses the possibility of Dasein's death in great detail, he never supports suicide and actually opposes the act. Though he tends to be more comfortable moving his thoughts towards skepticism rather than dogmatism, ${ }^{52}$ he nevertheless condemns the suicide of skeptics. He writes in Being and Time:

A sceptic can no more be refuted than the Being of truth can be 'proved.' And if any sceptic of the kind who denies the truth, factically is, he does not even need to be refuted. In so far as he is, and has

${ }^{51}$ Ibid., 198.

${ }^{52}$ Dahlstrom, Heidegger's Concept of Truth, 415. 
understood himself in this Being, he has obliterated Dasein in the desperation of suicide; and in doing so, he has obliterated truth. ${ }^{53}$

It is difficult not to recall that freedom for Heidegger was closely related to facing the possibility of death. Not just any death, but one's own death. It follows that authentic Being-towards-death has to at least include the possibility of contemplating the thought of one's actual death, and not just no longer being.

Consequently, Being-towards-death could also involve the possibility of contemplating not only death of natural causes, or sudden death by accident, but also death of one's own doing. However, this is not a mere omission on Heidegger's part. Rather it goes to the very heart of Heidegger's thought. Heidegger was always careful not to confuse the 'reality' of one's death or one's actual death, with death as a larger concept that represents the finitude of Dasein. In other words, contemplating the way one may die is simply out of the scope of Being and Time. What is important is the reality that one will one day no longer be.

The future possibility of Dasein's no longer being is a difficult reality to accept because Dasein exists, or is thrown, in a world that does not allow it to contemplate its death. He writes:

As thrown, Dasein has indeed been delivered over to itself and to its potentiality-for-Being, but as Being-in-the-world. As thrown, it has been submitted to a 'world', and exists factically with others. Proximally and for the most part the self is lost in the 'they. ${ }^{, 54}$

${ }^{53}$ Heidegger, Being and Time, 229.

${ }^{54}$ Ibid., 383. 
This insight resonates with Tolstoy's in The Death of Ivan Ilich, a story that Heidegger admits directly influenced him. ${ }^{55}$ In the story, the dying Ivan Ilich makes those around him afraid of their own death, and is himself, oscillating between despair and denial. As Tolstoy writes:

Ivan Ilich saw that he was dying, and he was in a continual despair.

In the depth of his heart he was dying but not only was he not accustomed to the thought, he simply did not and could not grasp it. The syllogism he had learned from Kiezewetter's Logic: "Caius is a man, men are mortal, therefore Caius is mortal," had always seemed to him correct as applied to Caius, but certainly not as applied to himself. ${ }^{56}$

Heidegger agrees that Dasein is in denial about his own death the way Ivan was, he also contends that Dasein learns this denial from 'the they,' who comprise Dasein's world. Provided Dasein does face its own death and becomes "Beingfree for death," thus grasping the finitude of its existence, it will gain "the simplicity of its fate. ${ }^{\prime 57}$ Once Dasein gains its fate, it also comes to realize that decisions made are its own. In this fashion, Dasein gains agency. This, in turn, generates the awareness that one is ahead of oneself. From this position Dasein can reclaim his present and his sense 'self.'

Though by facing its death, Dasein necessarily understands itself as removed from 'the they,' who will after all continue to live, Dasein still does not remove itself from the world. There is thus, a communal character to Dasein that

\footnotetext{
${ }^{55}$ William Barrett, The Illusion of Technique (New York: Anchor Books, 1979), 258. ${ }^{56}$ Leo Tolstoy, The Death of Ivan Ilych and Other Stories, trans. Aylmer Maude and J.D. Duff (New York: A Signet Classic, 1960), 129.

${ }^{57}$ Heidegger, Being and Time, 384.
} 
keeps it anchored in the world despite the wondering in thought that occurs in the solitude of contemplating one's own death. As Heidegger writes:

Destiny is not something that puts itself together out of individual fates, any more than Being-with-one-another can be conceived as the occurring together of several Subjects. Our fates have already been guided in advance, in our Being with one another in the same world and in our resoluteness for definite possibilities. ... Dasein's fateful destiny in and with its 'generation' goes to make up the full authentic historizing of Dasein. ${ }^{58}$

While it is true that Being-towards-death holds the possibility of removing Dasein from its world, this is only a possibility in thought. In more pragmatic terms, this is neither possible, nor desirable. It is impossible because Dasein is never out of its world, even though, in thought, Dasein may contemplate itself as no longer part of this world.

Finally, Being-towards-death is not an exercise Dasein can engage in physically, nor even attempt. It is meant as an exercise in thought, in which Dasein becomes the site of disclosure. If this site is terminated, then the very contemplation of Being, for which Dasein as entity was constructed in the first place, also ceases to exist. This contemplation of one's finitude as Being-towardsdeath, leads to an authentic self typified by care. Care, in turn, bestows on Dasein a renewed concern for its own life: a care to live. Dasein, understood as 'Beingopen,' requires a contemplation of one's death as finitude in thought, while Dasein as 'Being-here' renders the action of suicide nonsensical.

${ }^{58}$ Heidegger, Being and Time, 384. 
Hence the two translations of Dasein illustrate how suicide can be at once an undesirable action and an instrumental thought experiment that psychiatrists (and even bio-ethicists) may be tempted to use to prevent suicide. Psychiatrist James Werth's bold attempt at using rational suicide to open up possibilities for life and, persuade his patient not to commit suicide, can be justified in this Heideggerian context. However, this openness towards possibility envisioned by Heidegger is always, and necessarily, grounded in the world.

\section{Concluding remarks}

Suicide will continue to remain the most personal of acts and it will continue to make us feel uneasy. But our perception of suicide is changing and certain aspects of it will likely remain permanently changed. One is the belief that the suicide is the work of the devil. Another is the belief that suicide is necessarily a case of mental illness. Yet another change pertains to our inuring to some forms of suicide, such as anomic and egoistic forms, while continuing to consider irrational forms of suicide that are not common to the Western society such as fatalistic and altruistic. The more recent trend of rationalizing suicide, on the other hand, is likely to become more common in part because of advancements in medical technology that prolong the suffering often accompanying the dying period.

Like all changes, the rationalization of suicide will come with its share of dangers. One clear danger is the use of rational suicide as a psychiatric tool to encourage living. Werth's psychiatric approach, involving the use of suicide to 
anchor one in this world, can have disastrous implications. These implications become most evident when the contemplation of one's own death is removed from its philosophical context and turned into a rhetorical artifice to persuade against suicide. In short, being open to one's own death can only be contemplated in thought if, and only if, one is also simultaneously aware of his anchoring in a world of care, characterized by Dasein as 'Being-Here.'

Heidegger makes alluring references to possibilities. He opens dangerous freedoms for contemplation and he even raises possibility higher than actuality. Yet, in the end, he is still able to separate the contemplation of one's own death in thought from the actual act of committing suicide. Suicide, after all, according to Heidegger, is actually nonsensical. This is a distinction that gets to the heart of philosophy as the need to separate thought from action. It is on this separation that all other possibilities for both thought and action rest. 


\section{Chapter 3. Euthanasia and judging 'the good death'}

Euthanasia is derived from the Greek words eu (good) and thanatos (death). This etymology implies that a certain standard must have existed in the past, and may still exist today, for judging whether someone's death is 'good.' To preserve the ambiguity contained in the root words that form euthanasia, I propose expanding our current understanding of euthanasia, the practice of ending life painlessly, to include the practice of dying well.

This chapter begins with a brief history of what the good death had entailed in the past and it shows that, while people always died, they died and lived differently depending on how they made sense of death. Dying was always associated with judgment, even though this judgment was sometimes a solitary verdict passed on one's self, passed by others, or passed by God. More importantly, as this work will show, previous ways of judging the good death were based on one's entire life rather than the moments leading up to death. Consequently, the judgment of a good death was ethically broad. At no other point in history have we expected a mere law to define the criteria for judging the good death as we are beginning to now.

I then summarize the debates about euthanasia in North America and Western Europe and show that modern arguments for it, rooted in empathy for the terminally ill, reflect Heidegger's understanding of 'authentic being with others.' This is because 'authentic being with others' also involves a relation to others grounded in empathy and care. The emphasis on empathy and care that characterizes authentic relations in society represent Heidegger's attempt to 
counter the solitary, and "free floating I" in German Idealism. These notions create a sense that liberal politics can be enriched through the inclusion of care and empathy and can thereby be made more authentic.

However, despite its allure, it must be remembered that Heidegger's notion of empathy is predicated on a common destiny. A common destiny, furthermore, that is not compatible with a liberal understanding of politics because it does not allow for plurality and for ethical differences. Nevertheless, Heidegger's work is instrumental for revealing dictatorial elements present in the modern practice of euthanasia.

In the end, I argue that if the good death is understood as a painless death, and if empathy for the suffering is legal grounds for killing those in pain, then the standard for judging the good death becomes ethically narrow. This narrow standard subordinates ethics to the law and legitimizes dictatorial decisions over life and death.

\section{Historical overview of the 'good death'}

Margaret Battin, a prominent bioethicist writing about end of life issues, identifies certain cultural constructs behind the phrase 'natural death.' The dying patient may assume, when hearing the term, "that it will allow time for reviewing life and saying farewell to family and loved ones, for last rites or final words, for passing on hopes, wisdom, confessions, and blessings to the next generation." Yet, she continues, "[t]hese ideas are, of course, heavily stereotyped; they are the product of literary and cultural traditions associated with 
conventional deathbed scenes, reinforced by movies, books, news stories, religious models, and just plain wishful thinking."11 Although my examination of cultural and historical underpinning in the next sections risks romanticizing and oversimplifying the past, acknowledging this history is important for understanding euthanasia. This historical overview begins with a brief overview of dying in the early Middle Ages because some of the cultural stereotypes, to borrow Battin's phrase, were formed during this period.

\section{The Christian death}

Philippe Aries coined the term 'tame death' to characterize dying in the Early Middle Ages. The great cultural historian Johan Huizinga also acknowledged that the Christian preoccupation with the after life had not yet reached the many in the Early Middle Ages, affecting mostly the clergy. ${ }^{2}$ Peasants and noble men continued to die a slightly different death than those from the High Middle Ages. They died, to use Aries' terminology a 'simple' death. And, they were able to die a simple death because the possibility of death was always near. The lives of the old knights, for instance, were centered around the battle field and they therefore lived in the vicinity of death. These individuals had little time for contemplation. Knights understood when their deaths were immanent. When it came they lamented their life's end, expressed joy for the lives they had lived, pardoned others who had wronged them and finally turned their thoughts to God before

\footnotetext{
${ }^{1}$ Battin, The Least Worst Death, 34.

${ }^{2}$ Johan Huizinga, The Autumn of the Middle Ages, trans. Rodney J. Payton and Ulrich Mammitzsch (Chicago: University of Chicago Press, 1996), 156.
} 
allowing death to take its course.

Early Middle English literature also depicts warriors of that period taking a similar approach to death, as outlined by Aries. Beowulf, for instance, is aware that his death is near. As the narrator tells us, Beowulf "was well aware that his life's course, with all its delights, / had come to an end; his days on earth were exhausted, death drew very close." ${ }^{\prime 3}$ Beowulf's last words include all of the aforementioned elements. Beowulf laments his departure, gives thanks to God for his life, thinks of his people, and finally resigns to death. He begins by stating his regrets: "It would have made me happy, at this time,/ to pass on war-gear to my son, had I/ been granted an heir to succeed me/ sprung from my seed. ${ }^{\prime 4} \mathrm{He}$ then expresses joy for his life: "Because of all these things/ I can rejoice, drained now by death-wounds." ${ }^{5}$ This is followed by thanks to God: "With these words I thank/ the King of Glory, the Eternal Lord, / the Ruler, for all the treasures here before me." ${ }^{\prime 6}$ Finally, he resigns himself to death "fate has swept/ all my kinsmen, and those courageous worriers, / to their doom. I must follow them."7

A similar approach to death is found in the Early Middle English Ballads. Like Beowulf, Lord Rendal dies with a similar resigned attitude: "O yes, I am dying, mother; make my bed soon,/ For I'm wearied with hunting and fain would lie down." ${ }^{8}$ Despite some of the cruelty associated with Barbara Allan, she too sees her death coming and resigns to it: "O, mother, mother, make my bed,/

\footnotetext{
${ }^{3}$ Beowulf, in. The Longman Anthology British Literature, ed. Anne Schotter, Vol. 1 (USA: Addison-Wesley Educational Publishers, Inc., 1999), 2712-2715.

${ }^{4}$ Ibid., 2716-1719.

${ }^{5}$ Ibid., 2726-2727.

${ }^{6}$ Ibid., 2784-2786.

${ }^{7}$ Ibid., 2805-2808.

8 "Lord Rendal," in The Broadview Anthology of Poetry, ed. Herbert Rosengarten and Amanda Godrick-Jones (Peterborough, Canada: Broadview Pres, 1993), st. 7.
} 
O, make it soft and narrow,/ Since my love died for me today,/ I'll die for him tomorrow.." As Huizinga remarks, the preoccupation with death has not yet entered the Western consciousness. Consequently, while men and women were not eager to die, nor did they attempt to resist death.

Moreover, in the Early Middle Ages, Christians and non-Christians "died alike. ${ }^{10}$ For Christians, the Day of Judgment came to play a significant role only later during the High Middle Ages. In the Early Middle Ages, and as late as the $7^{\text {th }}$ century, depictions of the Second Coming did not focus on the Final Judgment. Christ was going to return as promised to awaken the dead, but not to judge them for their sins. Rather, 'the punishment' consisted of a denial of eternal life for those who had not been Baptized. ${ }^{11}$ Therefore, Beowulf, standing on the threshold between the old call for revenge and the Christian warning against excessive pride, could still say "the ruler of Men will have no cause to blame me." ${ }^{\prime 2}$ Likewise, St. Augustine could still write the City of God without making a single reference to Hell.

During the High Middle Ages, death began to have a human face associated with it. This transition is well illustrated in Guyot Marchant's edition of Danse Macabre from 1486. This depiction does not represent death, and does not even represent the skeleton, as a common symbol of death, but uses putrefying corpses instead. According to Huizinga, this picture is outdone in morbidity by older depictions in which the dancer is himself dead: a mirror

\footnotetext{
9 "Barbara Allan," in The Broadview Anthology of Poetry, ed. Herbert Rosengarten and Amanda Godrick-Jones (Peterborough, Canada: Broadview Pres, 1993), st.11. ${ }^{10}$ Philippe Aries, Western Attitudes toward Death (Baltimore, Maryland: John Hopkins University Press, 1974), 7.

${ }^{11}$ Tbid., 29.

12 Beowulf, 2728.
} 
image of the living who are about to die. In Huizinga's words: "you, yourself, are in the danse macabre, and this is what bestows on it its gruesome powers."13

It is difficult to attribute the origin of these depictions to causes other than the Black Death. Surprisingly, however, even though Huizinga' deals specifically with the Middle Ages, and dedicates an entire chapter to the practice of dying during this period, he does not mention the plague. Perhaps he assumes it to be evident. He does nevertheless include a description of the burial procedures at the time. He writes:

The rich and the poor rested there side by side, but not for long, as the burial ground, which twenty churches had the right to use, was in so much demand that after a few years the bodies were exhumed and the tombstones sold... The skulls and bones were then piled up in the bone chambers above the Hall of Columns that surrounded the cemetery on three sides. They lay there in their thousands, open and exposed, preaching the lesson of the equality of all. ${ }^{14}$

This lesson of equality is even more significant if we consider how much things had changed from the Roman burial rituals. The Christians had brought the burial grounds inside the city walls. The tenth tablet of the Roman law of the Twelve Tablets forbade burials inside the city: Hominem mortuum in urbe ne sepelito neve urito (no man may be cremated or buried in the city) and, consequently, Roman cemeteries were located outside of the city. However, the cult of the martyrs, originating in North Africa, introduced the new belief that, if a Christian was buried near the martyrs then his chances of salvation would

\footnotetext{
${ }^{13}$ Huizinga, The Autumn of the Middle Ages, 166.

${ }^{14}$ Ibid., 170.
} 
increase. Thus, one might "be associated with the martyrs through the union of the tomb, in order that in the vicinity of the blood of the saints he may draw upon the virtue which purifies our souls against fire." ${ }^{\prime 15}$ And though the saints were initially buried outside of the city, a basilica would be built over their tombs. Subsequently other Christians would seek burial near it to ensure their salvation. Over time, this practice, according to Aries, blurred "the distinction between the abbey, with its cemetery, and the cathedral church."16 Even though some of the earlier Christians, amongst whom most notably St. John Chrysostom, opposed this practice, their views were disregarded ${ }^{17}$ and cemeteries became incorporated within the city walls.

Consequently, city life developed in the vicinity of the dead, making the macabre familiar. As Huizinga notes: "there amid the continuous burials and the exhumations was a promenade and a meeting place. Small shops were found near the bare bones and easy women under the arcades... Even festivities were held there. ${ }^{118}$ Or, in Aries' more colorful language, the cemetery became a quasiRoman forum.

"thus, within this asylum called a cemetery, whether or not bodies were buried there, people began to reside.....More broadly speaking people became accustomed to meeting within this asylum, as had the Romans in the Forum or the Mediteraneans on the Plaza Major or the Corso, in order to carry on business, to dance and gamble, or simply for the pleasure of being together. Shops and merchants appeared

\footnotetext{
${ }^{15}$ Aries, Western Attitudes Toward Death, 16.

${ }^{16}$ Ibid., 17.

${ }^{17}$ Ibid., 15.

${ }^{18}$ Huizinga, The Autumn of the Middle Ages, 170.
} 
along the charnel houses." ${ }^{19}$

Although, the Church did frown on the dancing and the theatrical troops, it was not until the late 1600 s that a more general sense of discontent with this setting emerged. This setting remained for almost a millennia ${ }^{20}$ and it is conceivable that, in this environment, it would not have been registered as strange or macabre for the worker to sing while digging Ophelia's grave as it would appear today. As a matter of fact, it is conceivable that Hamlet would have been the more peculiar for asking: "Dost thou think Alexander looked o' this fashion i'the earth?....And smelt so? Pah!" Here, Shakespeare stands at the threshold of a different transition: one from a death that was matter of fact (though personalized) to one that was terrifying; one that, in Aries' stronger words, "raped the living." ${ }^{21}$

Indeed, beginning in the $13^{\text {th }}$ century the Last Day Judgment began to preoccupy the living. Hence, the familiar depictions of Second Coming represented by a court of justice presided by Christ on the high throne. These depictions were accompanied by the fires of Hell and by the balance sheet of one's life. While St. Augustine was arguably the first to introduce the autobiography to Christianity, the primary purpose of this personal recollection was not to keep track of one's sins, but rather to act as a testimony of one's self through time. It was the testimony of a being that had memory, attention and will and was subject to an interventionist God.

By the fifteenth century, the liber vitae nonetheless became a personal

\footnotetext{
${ }^{19}$ Aries, Western Attitudes Toward Death, 24.

${ }^{20}$ Ibid., 25.

${ }^{21}$ Ibid., 56.
} 
balance sheet presented at the Day of Judgment. Religious iconography depicts this change with paintings of men and women holding their own book of life and standing ready for a final reading at the Day of Judgment. The Final Judgment became linked to an individual autobiography, meant to keep a close record of one's sins.

This emphasis on one's life might have generated, or at any rate contributed, to a new genre of treatises on the proper manner of dying: the ars moriendi. These texts were primarily the Church's response to the Black Death. They were meant to guide the Christians throughout those difficult times. The social upheavals that followed the Black Death during the 1500s ensured the ars moriendi additional relevance and historical continuity. These texts were translated in all Western European languages and acted as a guide for preparing Christians for the good death. The ars moriendi were adopted by various Christian denominations after the Reformation. Though they played a more central role for some, such as the Methodists, and a more minor one for others, such as the Catholics, they testify to a shift towards an understanding of death as purely one's own.

The ars moriendi continued to play an important role for Christians in both Europe and North America until the Nineteenth Century. How significant its role really was in America is subject to debate. According to James Farrell, the Congregationalists and the Unitarians progressively abandoned the ars moriendi in America and replaced the fear of death with the joy of living. According to Shai J. Lavi, the Protestant and the Methodist denominations continued to place great importance on the ars moriendi, but progressively replaced the Last Day Judgment with a judgment passed by family and friends on one's deathbed 
based on how fearless he was in the face of death. According to Lavi, amongst the Methodists, the final hours of one's life were a time of great exultation and the dying person, surrounded by family and friends, would "end like a fearless solider ready to die a triumphant death." This manner of facing death bravely was also referred to as "euthanasia," 22 or the good death.

Thus, euthanasia came to be associated with three layers of judgments: one's own judgment; the others' judgment of one's death; and God's Judgment on the Day of Judgment. This multilayered understanding of euthanasia, or of what constitutes the good death, is also the source of current debate about the meaning of the word euthanasia in secular vocabulary, especially the more recent use of the word euthanasia to denote painless death.

The romanticizing of death

After the Renaissance, representations of the good death diverged into religious and secular. ${ }^{23}$ Though there continues to be interaction between the two, each has

${ }^{22}$ Shai J. Lavi, The Modern Art of Dying: A history of Euthanasia in the United States (Princeton: Princeton University Press, 2005), 4. Lavi's study on euthanasia resembles my own because he also relates elements of Heideggerian thought to euthanasia. However, it differs because Lavi uses Heidegger to understand euthanasia from the perspective of Heidegger's work on technology. In so doing, he argues that the art of dying has been transformed into a technique, giving one the false impression that one can control one's death when, in reality, one is subject to technological thought. My study, by contrast, examines whether Heidegger's thought can be applied to modern end of life issues; not whether modern end of life issues reflect Heidegger's understanding of modernity.

${ }^{23}$ As an aside, the historical delineation between the Middle Ages and the Renaissance is far from clear. I want to single out one feature, which is the similarity between the change in religious portrayals of the afterlife, especially evident in the paintings of the Day of Judgment and the ars moriendi and the raise in scientific pursuit. While it is common to regard them in direct opposition they 
developed distinct features. In more practical terms, while traditional religious representations of death persist to this day, the secular ones are increasingly emphasizing the hospital death. Before engaging the literature on 'hospital death,' it is important to include an overview of the tuberculosis epidemic because the way this epidemic was handled during that period marked a radical change in the way Westerners began to perceive death.

I begin the discussion of dying and death in the eighteen hundreds with a representation of death from the Renaissance by Hans Baldung Grien. Rider and Death of a Maiden reveals the early signs of rebellion against death. Death is still one's own, but it is no longer the macabre of the earlier dance. Instead, it comes to represent a struggle with death. Grien's painting depicts the fight against death as personified by a man's hand raised against death's hourglass.

A similar resistance to death is even detected in Hamlet's rage over his failure to prevent Ophelia's death. By the nineteen hundreds, this rage against death intensified. We see it in the visual arts, as well as the poetry of the times. By the nineteen hundreds, the examples become even more radical, as, for instance Dylan Thomas' advice to his father suggests: "Do not go gentle into that good night, / Rage, rage against the dying of the light."

This transition towards a fight against death cannot be understood without taking the tuberculosis epidemic into account. Lasting from the late 1700s up until the mid 1800s, this epidemic left a permanent mark on Western

share one important feature: both approaches reveal a bold thrust towards the mastery of the unknown. The Church goes bolder than ever before towards the unknown of the afterlife, which it masters in its iconography and the sciences towards the mastery of nature. Arguably, the later of the two will immerge victorious but the impulse to master the unknown is shared during the High Middle Ages and early Renaissance. 
perceptions of death. ${ }^{24}$ Like other epidemics, tuberculosis was indiscriminant, affecting both the rich and the poor, both simple men and men of genius. The scale of this disease was unprecedented. It is estimated that four million people died each year of tuberculosis in the 1800s, making it the most catastrophic of all diseases in history.

Tuberculosis, however, differs from other epidemics because it was heavily romanticized. Indeed, this romanticizing was so powerful in the West that some people imagined themselves to be infected with tuberculosis. These people imitated the symptoms, as did, for instance, Dylan Thomas as late as the mid 1900s. ${ }^{25}$ In fashion, women replaced their vivid colors of dress and skin tones from the time of the Revolution with vaporous white and a pale complexion. So pronounced was this trend that, according to Thomas Dormandy, young women took to drinking lemon juice and vinegar to kill their appetites and to make themselves look more alluring, thereby symbolizing the death of consumption. ${ }^{26}$

In Nineteen Century literature, the characters dying of consumption abound across cultures. Such characters could be found in several novels, including: Jean Eyre, Wuthering Heights, Crime and Punishment, Lady of the Camellias, The Magic Mountain and arguably even the Chinese novel The Dream of the Red Chamber. Edgar Allan Poe referred to tuberculosis as "the terrible beauty of consumption" and describes his wife Virginia as "delicately, morbidly angelic." He described her cough, for instance, in a style of his very own:

${ }^{24}$ Thomas Dormandy, The White death: A history of Tuberculosis (New York: New York University Press, 1999), 73.

${ }^{25} \mathrm{H}$. D. Chalke, "The Impact of Tuberculosis on History, Literature and Art," Medical History, 6 (Oct 1962): 301-318.

${ }^{26}$ Dormandy, The White death, 91. 
"Suddenly she stopped, clutched her throat and a wave of crimson blood ran down her beast....It rendered her even more ethereal!"27 To the vast list of creative works are added the many men of genius that also struggled with the disease. Among them were: Friedrich von Schiller, Spinoza, John Locke, Immanuel Kant, Voltaire, Jean-Jacques Rousseau, and Dmitri Mendeleev, to mention but a few.

John Keats provides another enduring example of the romanticism that accompanied the tuberculosis epidemic. In some ways, his life merged fully with his suffering for the disease and its excruciating treatment, consisting of starvation, blood-letting, antimony, and the avoidance of sedatives. ${ }^{28}$ His personal suffering merged with his poetry. Keats last words are said to have been: "thank god it has come." ${ }^{29}$ In spite of his illness, Keats wrote with urgency and always maintained a tone of melancholy symptomatic of the disease.

Just a few decades later, tuberculosis would became the mark of both elites and men of genius, and the product of the most romantic depictions. For instance, in Renee Mauperin's scientific account of the time:

In contrast to other diseases of crude and baser kind which clog and soil the mind, the imagination and the humours of the sick, phthisis is an illness of the lofty and noble parts: it calls forth a state of elevation, tenderness and love, a new urge to see the good, the beautiful and the ideal in everything, a state of sublimity which seems almost not to be

${ }^{27}$ Dormandy, The White death 94.

${ }^{28}$ Ibid., 20.

${ }^{29}$ Ibid. 
of this earth. ${ }^{30}$

By the early 1900s, the medical verdict followed suit: "the toxins of tuberculosis stimulate the creative instinct and promote literary brilliance. ${ }^{131}$ The tuberculosis epidemic thus merged death with creativity and imbued them with a sense of solitary pursuit.

The good death, by ramification, became understood as an end to a life lived intensely. As Marie Duplessis would say in La Dame aux Camelias: "I shall not live as long as others, I have promised myself to live more quickly." ${ }^{\prime 2}$ This fusion of death and creativity formed the basis for nineteenth century Romanticism and it is well summarized in M.H. Abrams: "The inescapable cost of creation is suffering, of which creativity is the priceless reward, and the artist must die to involvement with the world in order to be reborn to the detachment of the artist." 33

Meanwhile, in Germany, reputable physicians began to argue that tuberculosis did not exist in mountainous countries. This facilitated a mystical association of spiritual and physical renewal with the mountains. It was, Dormandy argues, "one of the most pervasive images to which German

${ }^{30}$ Dormandy, The White death, 93.

${ }^{31}$ Chalke, "The Impact of Tuberculosis on History, Literature and Art," 313.

32 Ibid., 308.

${ }^{33}$ M.H. Abrams, Natural Supernaturalism: Tradition and Revolution in Romantic Literature (New York: W.W. Norton \& Company Inc., 1971), 82. This study is particularly instrumental in showing the degree to which the Romantic movement was itself the product of Christian Weltanschuung. He writes: "If we nonetheless remain unaware of the full extent of which characteristic concept and patters of Romantic philosophy and literature are a displaced and reconstituted theology, or else a secularized form of devotional experience, that is because we still live in what is essentially, although in derivative rather than direct manifestations, a Biblical culture, and readily mistake our hereditary ways of organizing experience for the conditions of reality and the universal forms of thought." 66. 
Romanticism had given birth: and it lingered on longer than most of the movements' other accouterments." Thus, the success of physicians such as Brehmer in curing tuberculosis is not supported with experimental or empirical proof. Rather, it can be traced, Dormandy argues, more to "the lyric poetry of Goethe, the songs of Schubert and the vision of moonlit forests and snow-capped mountain peaks by Caspar Friedrich than to scientific mumbo-jumbo about metabolic purification. ${ }^{34}$

The institutionalization of tuberculosis

Despite the cultural association of spiritual and artistic creativity with tuberculosis, the disease was also being fought by scientists, medical doctors, and, of course, the modern state. Indeed, before a vaccine was invented to prevent tuberculosis, and before antibiotics were used to cure it, the modern state had adopted the sanatorium as a solution. It was a solution loyal to a culture that began to resist death, but that now began to involve the state in its struggle with death. Few novels capture this development as well as The Magic Mountain. Leaving aside the discussions over the utility of an encyclopedia of pain that fascinated Settembrini and fueled his disagreements with Naptha, the fact remains that Hans Castrop's illness was mysterious. Although the sanatorium was created to cure people with diseases, doctors decided to hospitalize Castrop even though he lacked symptoms. Thus, begins Castrop cure for a disease he did not seem to have. After the preoccupation with blood letting

${ }^{34}$ Dormandy, The White death, 150. 
and other invasive, but ineffective, medical treatments that typified medicine for hundreds of years, it is not surprising that Thomas Mann, and others of his generation, distrusted the medical profession.

The lack of trust in the medical profession, combined with a false belief that tuberculosis heightened creativity, resulted in a demonization of the sanatorium. This demonization is powerfully illustrated in Rainer Maria Rilke's writings. Rilke no longer retained that aura of creativity around the sanatorium the way Thomas Mann does. For Rilke, the sanatorium was a place that killed creativity while attempting to cure the disease. In The Notebooks of Malte Laurids Brigge, which, like The Magic Mountain, is also semi-autobiographical, Rilke offers one of the most critical accounts of the sanatorium:

This excellent hotel is very ancient. Even in King Clovis' time people died in it in a number of beds. Now they are dying there in 559 beds. Factory-like, of course. Where production is so enormous an individual death is not so nicely carried out; but then that doesn't matter. It is quantity that counts. Who cares anything today for a finely-finished death? No one. Even the rich, who could after all afford this luxury of dying in full detail, are beginning to be careless and indifferent; the wish to have a death of one's own is growing ever rarer. A while yet, and it will be just as rare as a life of one's own. Heavens, it's all there. One arrives, one finds a life, ready made, one has only to put it on. One wants to leave or one is compelled to: anyway, no effort: Voila votre mort, monsieur. One dies just as it comes; one dies the death that belongs to the disease one has (for since one has come to know all diseases, one knows, too, that the different 
lethal terminations belong to the diseases and not to the people; and the sick person has so to speak nothing to do). ${ }^{35}$

There are indeed good reasons for distrusting the sanatorium. In its early stages, it was inefficient at curing people and only brought people together to die in an organized fashion. As Dr. Jenner Hoskins, a London cardiologist, jadedly stated: "Recovery no, progress yes: but progress to the grave."36

Yet, this is not the first time in European history that people died in close proximity to one another. What changed, however, was the cultural setting of the 1800s, in which death by tuberculosis had been so romanticized that it had become a mark of creativity and distinction. Consequently, the sanatorium progressively lost its appeal and became an action sanctioned by the state and the medical profession against creativity, rather than an action against tuberculosis.

Rilke's lament for a death of one's own will also have a strong impact on Heidegger but for now I want to summarize a few important points from this historical overview. First, in the Early Middle Ages, dying well was strongly associated with resignation. Though mourning rituals were prevalent, people maintained a simple, more matter of fact, approach to death that mirrored the way they lived their own lives. By the High Middle Ages, the Day of Judgment increased in significance, culminating in the ars moriendi. Hence, death became one's own, and ars moriendi provided a standard for judging the good death. By the 1800s, among some Christian denomination, this standard became applied by

\footnotetext{
${ }^{35}$ Rainer Maria Rilke, The Notebooks of Malte Laurids Brigge, trans. M.D. Herter Norton (New York: W.W. Norton \& Company, 1964), 17-18.

${ }^{36}$ Dormandy, The White death, 163.
} 
the community to dying men and women. The Christian world thus had fused euthanasia with a three layered judgment of the good death.

The secular views of death, on the other hand, began framing the good death in a different manner. There was an element of rebelliousness against death that proved futile when faced with the tuberculosis epidemic. During the 1800s, this epidemic became culturally fused with creativity. Consequently, literature and art became vehicles for advocating an intensely lived life and a death that was not only one's own, but that also testified to one's creative life. This celebratory attitude was lost with the advent of the sanatorium. As a result, we continue to preserve a strong resistance to the modern practice of euthanasia, understood as a painless death that is facilitated, or even made possible, by 'qualified' professionals. This resistance emerged from two different views of death: a Christian and a secular one.

Importantly, throughout the Western world, judgments about the good death continued to be closely linked to the manner in which one lived. Or, more accurately, the good death was a verdict not so much on how one died, but more so on how one had lived. Indeed a life lived simply and in the vicinity of death generated a simple mode of dying. An intense appreciation of life in the Renaissance generated a sense of rebelliousness against death. The tuberculosis epidemic that was considered to unleash creativity, then romanticized the suffering associated with dying. Yet, although certain trends are noticeable in the way people died during different historical periods, none of these periods had a universal standard by which to judge the good death. 


\section{Euthanasia in Nazi Germany}

Modern arguments for euthanasia are now often based on feelings of empathy and this highlights an important transition from previous ways of judging the 'good death.' Before proceeding to the topic of modern euthanasia it is important to examine the practice of euthanasia in Nazi Germany because Nazi justifications for euthanasia, though radical, has similarities with our own. The most important similarity is the belief that a clear standard can be established for determining when to terminate life. Furthermore, as the brief historiography from the previous section showed, the manner in which people judged the good death cannot be interpreted separately from the way in which they lived. Consequently, the commitment to a quick standard for judging the good death reveals an unprecedented limitation of our understanding of what a human life entails.

Both secular and religious, and indeed commonsensical opponents to euthanasia in today's society often mention to Germany's descent into Nazi barbarity. It was in Nazi Germany that the practice of euthanasia shed itself of all previous ways of judging the good death and replaced them instead with a single new standard: the health of the state. Even before the Nazis assumed power, there had been warning signs, not only in Germany, but also throughout the Western World that social Darwinism was paving a path for the implementation of eugenics on a mass scale. The implementation of eugenic practices calling for the elimination of people deemed 'inferior' never went beyond the sterilization of the mentally handicapped in North America. In 
Germany, however, arguments for eugenics generated the Holocaust.

This happened despite the fact that, as early as 1806 , fifty years prior to the publication of On the Origin of the Species, physicians had raised awareness about this new trend. German physician Christoph Wilhelm Hufeland had written: "It is not up to [the doctor] whether....life is happy or unhappy, worthwhile or not, and should he incorporate these perspectives into his trade....the doctor could well become the most dangerous person in the state." ${ }^{\prime 37}$ Unfortunately, Hufeland's warnings were overshadowed by the publication and subsequent popularity of Permission to Destroy Life Unworthy of Life, a book published in 1920 by Karl Binding, a law professor, and Alfred Hoche, a physician, that outlined three categories of patients whom doctors should be allowed to kill ethically: the terminally ill and mortally wounded, "incurable idiots;" and the "unconscious. ${ }^{\prime \prime 8}$ These categories provided the scientific and medical foundation for subsequent eugenics policies.

During the 1930s, Nazi propaganda under Goebbels worked to mobilize public opinion for euthanasia. One of those efforts is mirrored in the film I Accuse that became popular in the 1930s. ${ }^{39}$ As public opinion changed in Nazi Germany in favor of euthanasia, the medical profession also changed. Between 1933 and 1945, for instance the Hippocratic Oath was replaced with an oath to the health

${ }^{37}$ Wesley J. Smith, The Culture of Death: The Assault on Medical Ethics in America (San Francisco: Encounter Books, 2000), 37.

${ }^{38}$ Smith, The Culture of Death, 38.

${ }^{39}$ The protagonist of the movie is a pianist who is suffering from multiple sclerosis and begs for euthanasia. The side plot of the movie involves a child who is disabled and whose parents also beg for euthanasia for their infant. The child is killed off screen while the pianist commits suicide with her husband's help. At the trial the husband explains his action stating: "Now, I accuse! I accuse the law that hinders doctors and judges in their task of helping people. In, Smith, The Culture of Death, 40 . 
of the state, Gesundheit (health). ${ }^{40}$

To accommodate these changes, the language used to discuss euthanasia also had to change. For instance, children born with disabilities were sent to 'health centers,' operating under Dr. Karl Brandt's supervision. These centers performed the "'healing' service for the child, the family and the Reich," meaning they killed the disabled. ${ }^{41}$ The T-4 Program was then created to expand the practice of eugenics to include people with epilepsy, polio, schizophrenia, senility, paralysis, and Huntington's disease. The T-4 Program was highly bureaucratized and originally kept hidden from public view. However, given the magnitude of its operations, the program did not remain a secret for long. Even Himmler himself admitted that euthanasia was "a secret that is no longer a secret." ${ }^{12}$ The program was eventually rescinded, but the practice continued on a smaller scale with an estimated death toll of 250, 000 people by the end of War World II. Even after the war Dr. Ernst Wetzler, one of the participants, and ironically, inventor of the incubator for prematurely born babies, considered the act of killing disabled infants "a small contribution to human progress."

During the war, the expansion of Nazi Germany to the East made it possible to practice euthanasia on an even larger scale than before. This is because, as Hannah Arendt remarked, when contained in a smaller state, the totalitarian machine is forced to moderate in some way or risk loosing whatever

\footnotetext{
${ }^{40}$ Smith, The Culture of Death, 41.

${ }^{41}$ Ibid., 42.

${ }^{42}$ Tbid., 43.

${ }^{43}$ Ibid., 43
} 
citizens they have to rule over. ${ }^{44}$ With this expansion came the mass practice of medical experiments and the notorious concentration camps. Had Nazi Germany won the war, these practices would likely have been implemented on other Germans, since, Hitler had proposed, in the event they won "'to isolate' from the rest of the population all families with cases of heart or lung ailments among them, their physical liquidation being of course the next step in this program. ${ }^{\prime 45}$

During the time the Nazis were in power and implemented euthanasia, doctors played an important role. This began when doctors adopted a second loyalty to the state, and judged what lives were fit to survive based on this loyalty. In 1949, Dr. Leo Alexander wrote in the New England Journal of Medicine that the path to the Holocaust began on a small scale. In his words:

Whatever proportions these crimes finally assumed, it became evident to all who investigated them that they started from small beginnings. The beginnings at first were merely a subtle shift in emphasis in the basic attitudes of physicians. It started with the acceptance of the attitude basic to the euthanasia movement, that there is such a thing as a life not worthy to be lived. ${ }^{46}$

The practice of euthanasia in Nazi Germany was in accordance with Hitler's dictum that "the total state must not know any difference between law and ethics" because, explains Arendt: "if it is assumed that the valid law is identical with the ethics common to all and springing from their consciences,

\footnotetext{
${ }^{44}$ Hannah Arendt, The Origins of Totalitarianism (Orlando, Florida: Hartcourt, Inc., 1966), 310.

${ }^{45}$ Ibid., p. 310 , footnote 16.

${ }^{46}$ Smith, The Culture of Death, 45.
} 
then there is indeed no further necessity for public decrees." ${ }^{\prime 7}$ As such, physicians were no longer expected to practice medicine according to their traditional code of ethics, but rather to abide by the Nazis laws and to judge which lives ought to be terminated to effectively ensure a 'healthy state.'

\section{Modern euthanasia}

The horrific Nazi period continues to serve as one of the main counter points against the modern practice of euthanasia. For this reason, current supporters of modern euthanasia begin by disassociating themselves from the Nazis. Indeed, modern arguments for euthanasia never make an appeal to the good of the state. They focus instead on the need, and occasionally even the duty, to act out of mercy or empathy towards dying patients. However, underlining these new arguments lurks the old danger, as described by Hannah Arendt, of obliterating the difference between law and ethics. This difference is the essence of an open society, and it is of paramount importance to understanding the current debates on euthanasia.

While laws and ethics inevitably interact, they also differ in a few ways. Appeals to the law are generally more logical and impersonal, while ethical principles often transcend legal norms and challenge them based on changing circumstances in society. This flexibility is build into the common-law tradition itself and forms the basis for objectivity of precedence. Statutes, for instance, are

${ }^{47}$ Arendt, The Origins of Totalitarianism, 394. 
periodically amended. ${ }^{48}$

The extent to which laws are enforced and interpreted provides an indication of the strength of a state's rule of law. Laws that conflict with ethical norms are progressively ignored and eventually discarded altogether through legal reform. This was the case, for example, with race laws in the United States. Given the topic of this study, it is also the case with laws on suicide. Suicide was initially considered illegal and punishable by both the Church (refusal of burial) and by the State (confiscation of the estate). Yet, progressively, suicide was decriminalized in most of the Western World on grounds that people contemplating it should be encouraged to seek help.

Physicians' decisions to terminate life support or to prescribe powerful, though non-lethal, doses of painkillers, are currently issues being debated in western courts and these debates reflect the tension between laws and ethics. It is a tension that unleashes bitter controversies and, under extreme circumstances, even foster a luck of trust in the legal systems. However, the alternative of living in a world without this tension is even more problematic. A world in which ethics and laws are no longer allowed to interact and to retain their dynamic characters is a world committed to establishing homogeneity at all costs. To phrase it metaphorically, if Lady Justice begins to see and judge with her heart, then the objectivity for which she is praised would come to a halt, and, as such, ethics would no longer challenge laws because the two would become indistinguishable. Metaphors aside, the fusion of ethics with laws is the mark of a totalitarian state.

\footnotetext{
${ }^{48}$ Jerry B. Wilson, Death by Decision: the Medical, Moral and Legal Dilemmas of Euthanasia (Philadelphia: The Westminster Press, 1975), 126-127.
} 
Like right-to-die arguments, rooted in freedom of choice (or autonomy), the arguments for euthanasia have a darker rational. Modern arguments for euthanasia maintain that the elimination of a dying patient's suffering and pain must be the priority of medical physicians This can even entail killing a patient, provided that patient consents.

Yet, the patient's desire to die is insufficient to warrant euthanasia. The current practice of euthanasia requires, in addition, that medical physicians issue a diagnosis, indicating a patient is judged to be a suitable candidate for euthanasia. With this diagnosis, the physician can then prescribe and/or administer lethal drugs to his or her patient. When a medical physician or a family member directly administers a lethal drug that results in the death of a patient (i.e., a lethal injection), the procedure is referred to as active euthanasia. When the medical physician prescribes lethal drugs, but he does not administer these drugs directly, the practice is referred to as passive euthanasia. Although these preliminary definitions are sometimes ambiguous, they both imply that qualified and healthy human beings have the ability to judge when a patient's life can be terminated.

It is not my intention to over-simplify the issue of euthanasia by overlooking the autonomy of the patient. Here, I assume a patient's full consent, and I also assume a scenario in which the physician's diagnosis about terminal illness and intense suffering is correct. While the connection between suicide and euthanasia is rather strong, I distinguish the two based on the fact that, in the case of euthanasia, other people are involved either actively or 'passively' in bringing about one's death and that they are thereby involved in defining standards for judging a 'good death.' 
Some of the strongest criticisms against modern euthanasia have emerged from the Christian tradition. The Christian understanding of suffering underlies arguments made against euthanasia. As pointed out earlier, euthanasia itself was understood to mean the end of a life lived in accordance to God's will. From a secular perspective, the Christian approach is not without its share of limitation. As Battin remarks:

For the Christian, suffering - both one's own and that personified in Christ - is real, important, and in the end redemptive: it is the way to the beatific world beyond death.

But this emphasis on the value and centrality of suffering - even of the innocent - is open to a serious objection. If suffering is of value, it would seem to follow that, rather than work to reduce suffering among one's fellow and in the world at large, one ought to impose on them as much suffering as possible. ${ }^{49}$

This is, of course, a logical exaggeration. While Battin does acknowledge that even popular culture depicts suffering as serving the purpose of forging character, suffering, from a secular perspective, is linked to a utilitarian understanding of how much suffering is useful for the individual. Suffering is understood as either 'productive' and constructive or 'unproductive' and destructive. The problem with this distinction is that it is difficult to judge in advance the amount of suffering each person can endure before he becomes overwhelmed, and the suffering, therefore, 'unproductive.'

Notwithstanding differences between Christian denominations, whether

${ }^{49}$ Battin, The Least Worst Death, 234. 
they be Roman Catholics, Protestants, Anglican, or Orthodox, Christians believe that human life is a sacred gift from God. Accordingly, there is 'a time to live and a time to die,' and that time is in 'God's hands.' Moreover, they allow withholding treatment from a patient if he wishes and powerful painkillers. Though these practices often accelerate the process of dying, they are allowed because of the 'double effect' principle: the death of the patient is not the intention. Finally, all of these Christian denominations forbid active and passive euthanasia. $^{50}$

In response to Battin's almost mocking remark that Christians long for suffering, it must be pointed out that Christians maintain that human suffering is inevitable. Though it is true that they also see meaning in it, because it can teach humility, they also find in the model of Christ the resources needed to endure it. It is, in sum, opposite to the views espoused by secular critics. Christians are not prompted to go out of their way to suffer. Rather, they are taught to face suffering when they are confronted with it rather than to evade it. Yet, because their views are intimately bound up with faith in God and trust in His divine plan, the absence of faith does render the connection between suffering and dying hollow. Consequently the Christian way of approaching suffering is not a model that can be easily integrated with secular ethics.

\footnotetext{
${ }^{50}$ John Breck, The Sacred Gift of Life: Orthodox Christianity and Bioethics (Crestwood, New York: St. Vladimir's Seminary Press, 2000), 223. John J. Paris and Michel P. Moreland, "A Catholic Perspective on PhysicianAssisted Suicide," 324-329.

See also: Cynthia B. Cohen, "Christian Perspectives on Assisted Suicide and Euthanasia: the Anglican Tradition," 337-340 and Allen Verhey, "A Protestant Perspective on Ending Life: Faithfulness in the Face of Death," 352-357, in Physician Assisted Suicide: Expanding the Debate ed. Margaret P. Battin, Rosamound Rhodes, and Antia Silvers (New York: Routledge, 1998).
} 
Aside form the religious arguments there are also powerful secular arguments and strong activists opposing euthanasia. Among them The Euthanasia Prevention Coalition, founded in London Ontario, that successfully prevented euthanasia legislation from being adopted in Canada. More recently, it also successfully prevented pro-euthanasia adds from being aired on Canadian airwaves. ${ }^{51}$

Arguments against euthanasia also include loss of trust in our own physicians and the medical profession as a whole. As Somerville also remarks, since the practice of euthanasia necessitates thorough legal knowledge rather than medical expertise, then it may be more risk averse to allow lawyers, rather than physicians, to perform it. Also, considering the advancements in pain management, it is increasingly the case that palliative care is capable of alleviating intense suffering. Dying men and women thus do not need to undergo excruciating pain and could certainly avoid something as radical as ending their own lives.

Moreover, Somerville also indicates that invoking the concept of human dignity is itself problematic because we no longer share an understanding of what constitutes human dignity. Human dignity has begun to mean different things to different people. One of the dangers she outlines with this relative understanding of dignity is that it allows the possibility that all life, human and animal alike, is equal in dignity. Quoting Marino, Somerville argues that the danger of treating animals like persons is that persons also begin to be treated as

51 "Ad campaign for assisted suicide banned from Canadian airwaves" Globe and Mail, Monday Sep. 27, 2010. 
animals. $^{52}$

The modern belief in a good death being a painless death represents a narrowing of our conceptualization of human life. If the human proclivity to empathize with those who suffer is expected to motivate people to euthanize suffering humans, then the role of empathy in promoting care for suffering while they are alive is sadly being overlooked.

In the literature on bioethics, there is also a plethora of arguments appealing to emotion. These arguments are sometimes fabricated, sometimes real, and always profoundly touching. There is, for instance, the case of Chantal Sébire's plea. ${ }^{53}$ Sébire, a French citizen, appealed directly to president Nicolas Sarcozy for the right to end her life. A retired schoolteacher, Sébire suffered from a rare form of cancer that rendered her face unrecognizable due to growing tumors. She argued her case in court, but judges upheld the law against euthanasia. After loosing the case, she publicly announced her decision to end her life using illegally obtained lethal drugs. On March 21, 2008, Sébire was found dead and her autopsy revealed a high level of Pentobarbital, a barbiturate commonly prescribed in countries where euthanasia is legalized. Since her case became public, Sébire had often been quoted as saying: “one would not allow an animal to go through what I have endured."

Though Sébire's disease is rare, her plea for death is not and neither is her suicide. There is a growing black market for lethal drugs and the number of

\footnotetext{
52 Margaret Somerville, "Living with Dignity when Dying," presented on July 13 2011 at The Quebec Public Consultation on "Dying with Dignity."

53 "Chantal Sebire begs French president for the right to die," From correspondents in Dijon, France Agence France-Presse, February 27, 2008. Accessed April 10, 2009. http://www.news.com.au/story/0,23599,23283804-2,00.html
} 
'suicide tourists' traveling to countries where euthanasia is legal, such as Switzerland, is on the rise. My intention here is not to trivialize these individuals or to question their suffering. They epitomize the difficulty of facing dying and death. However, despite the compassion and empathy that their cases generate, their arguments for euthanasia are all rooted in the belief that pain and suffering must be avoided at all costs, even if it costs them their lives. Legalizing euthanasia would make evading pain the standard by which physicians judge whether to terminate a human life.

Arguments for euthanasia also involve a strategic use of emotional language. Glanville Williams, for instance, opts for the word 'cruelty' to describe the government's refusal to provide suffering patients with euthanasia. He claims that arguments for voluntary euthanasia involve two values:

The first value is the prevention of cruelty. Much as men differ in their ethical assessments, all agree that cruelty is an evil - the only difference of opinion residing in what is meant by cruelty. Those who plead for the legalization of euthanasia think that it is cruel to allow a human being to linger for months in the last stages of agony, weakness and decay and to refuse him his demand for merciful release..$^{54}$

The second value, which he admits is less compelling, is the agony of relatives seeing the loved ones suffering. In both cases the word cruelty is used to elicit a negative reaction to the suffering of others and to make euthanasia seem

\footnotetext{
${ }^{54}$ Glanville Williams, "'Mercy-killing' Legislation - A rejoinder" in. Contemporary Issues in Bioethics, ed. Tom L. Beauchamp and LeRoy Walters (Belmont, California: Wadsworth Publishing Company, 1978).
} 
necessary.

Since human beings cannot justify cruelty, it follows that they are dutybound to prevent it. Margaret Battin's argument for euthanasia goes one step further and uses the word 'duty.' She writes: The principle of mercy establishes two component duties: The duty not to cause further pain or suffering; and The duty to act to end pain or suffering already occurring. ${ }^{\prime \prime 5}$ Given the human proclivity to feel empathy towards the suffering, these arguments are powerful, but also very dangerous. They are predicated on the idea that empathizing with the suffering requires acting out of compassion towards them. With modern euthanasia, the act is to kill or facilitate the death of the suffering.

Likewise, the argument for euthanizing animals is also based on pity, where man is understood to be in a position of superiority and can act on feelings of pity to ease the suffering of an animal. When applied to human suffering, however, this can become a dangerous principle because healthier individuals are all of a sudden assumed to be in a position of superiority in comparison to the terminally ill. Moreover, these arguments imply that the healthy majority, whatever its characteristics, sets the standards used by medical physicians and legal professionals to judge whether those suffering are unworthy of living and ought to be euthanized in the name of empathy.

'The others' and 'the they' - empathy in Heidegger's thought

In light of this, I turn to Martin Heidegger's work on empathy. His work is

${ }^{55}$ Battin, The Least Worst Death, 102. 
appropriate for the current discussion on euthanasia because he uses empathy to create a sense of a more authentic and genuine politics rooted in care. Yet, as this chapter shows, despite the appeal to authenticity, Heidegger's notion of 'care' is nevertheless problematic for politics. The notion of care represents Heidegger's attempt to imbue the 'free-floating I' that typifies German Idealism with a sense of community and to allow it to develop relations with others based on empathy. Yet, this appeal to empathy is problematic because it eliminates the possibility of political disagreement. Following this I relate these findings to the present discussion of euthanasia and show that if empathy towards the suffering becomes the standard for judging the 'good death,' then the political tension between laws and ethics would disappear.

Thus, I begin with a preliminary overview of the relationship between 'others' and 'the they' and conclude with an overview of Heidegger's understanding of authentic resolution and its implications for the relationship between laws and ethics. In Being and Time, Heidegger outlines two different possibilities for relating to other people: one is authentic and the other is dangerously inauthentic. When Dasein relates to others inauthentically, he is said to be amongst 'the they,' or Das Man. As an entity, Das Man is abstract. It even lacks sex or gender and provides a powerful contrast to 'the others' who relate to Dasein authentically or concretely. Subsequent thinkers have adopted both of these notions. Derrida and especially Levinas have adopted authentic relations that typify others and attributed to them quasi-Christian proportion of love of 
others. ${ }^{56}$ Foucault, on the other hand, has adopted the inauthentic notion of 'the they' to represent an internalized sense of oppressive authority in society, or biopower.

In what fallows, I focus on the implication of Dasein in its plural form and show that, according to Heidegger, Dasein's authentic relations with others, are not desirable because they generate a world in which ethics and laws become indistinguishable. I also show that authentic relations with others are in fact inauthentic and resemble the relations with 'the they,' or Das Man.

I conclude, that Heidegger's thought preserves no logical avenue by which to maintain a separation between laws and ethics and consequently no avenue to prevent painless death from being understood unanimously and unquestionably as the good death. Yet, while Heidegger's work cannot provide us with a guide to institutionalize euthanasia within a liberal framework, his concept of "das man" can be employed to illustrate subtle dangers contained in the modern practice of euthanasia.

In Being and Time, Heidegger carefully to outlines the great difference between 'the they' and the 'others.' Linguistically he portrays 'the they' as an entity without sex or gender, characterized by their complete disconnect with

${ }^{56}$ There are indeed some Christian roots to the notion of care Heidegger developed yet Heidegger insists that the Christians did not understand care explicitly. As he explains in History of the Concept of Time: "It was seven years ago, while I was investigating these structures in conjunction with my attempts to arrive at the ontological foundations of Augustinian anthropology, that I first came across the phenomenon of care. Of course, Augustine and the Christian anthropology in general did not know the phenomenon explicitly, nor even directly as a term, although cura, care, already played a role in Seneca as well as in the New Testament, as it is well-known." (302) Heidegger judged the fable where Care comes to possess man to have a "particularly positive role for all interpretation." (302) 
Being. By contrast, the 'others' form a world that is, for the most part, Dasein's world. This begs the question: who, in pragmatic terms, are 'the they' and who are 'the others?' Would one's family necessarily be the 'others,' while the people one encounters on the bus 'the they?' Either interpretation would be a logical impossibility, because one's family members could very well take the public transit and engage in idle talk. These two entities are therefore more accurately conceptualized as fluid, or as being capable of shifting places and acting as both 'others' and 'they' depending on the context. We ourselves can be considered part of both 'the they' and 'the others,' and we can even be so simultaneously. The greatest danger, Heidegger maintains, occurs when this fluidity is lost and the 'others' become absorbed into 'the they: ${ }^{57}$ when the concrete particular becomes absorbed into an abstract notion such as 'the they.'

Moreover, though they are fluid concepts, there are nevertheless certain characteristics differentiating the 'others' from the 'they.' 'The others,' according to Heidegger, are not in a materialistic relationship and they do not become an extension of their work. They do, however, relate to one another through their work. In other words, their work bears testimony to their presence. In Heidegger's words:

When, for example, we walk along the edge of a field but 'outside it', the field shows itself as belonging to such-and-such a person, and decently kept up by him; the book we have used was bought at Soand-so's shop and given by such-and-such a person, and so forth. The boat anchored at the shore is assigned in its Being-in-itself to an

${ }^{57}$ Heidegger, Being and Time, 125. 
acquaintance who undertakes voyages with it; but even if it is a 'boat which is strange to us' $^{\prime}$, it is still indicative of Others. The Others who are thus 'encountered' in a ready-to-hand, environmental context or equipment, are not somehow added on in thought to some thing which is proximally just present-at-hand; such "Things' are encountered from out of the world in which they are ready-to-hand for Others - a world which is always mine too in advance. ${ }^{\prime 158}$

Dasein's relationship with 'others' resembles an Aristotelian public space, wherein citizens get together to engage in politics. It differs considerably, however, in that this public space does not allow room for difference. The relationship between Dasein and the others, when it is historically authentic, is characterized by a common or shared destiny. Heidegger writes:

When they devote themselves to the same affair in common, their doing so is determined by the manner in which their Dasein, each in its own way, has taken hold of. They thus become authentically bound together, and this makes possible the right kind of objectivity, which frees the other in his freedom for himself..$^{59}$

Interestingly, this relationship between authenticity and freedom does not associate authenticity with sentiments and subjectivity. Rather, authenticity is 'a right kind of objective' sense of Being-with-others. Even thought the right kind of objectivity that typifies authentic Being-with-Others does not allow for telos or for politics in the Aristotelian sense, and it is not predicated on sentiments of amour de soi in the Rousseauian sense, it does make empathy possible.

\footnotetext{
${ }_{58}^{58}$ Heidegger, Being and Time, 154.

${ }^{59}$ Ibid., 122.
} 
According to Heidegger, "Empathy does not first constitute Being-with; [rather it develops only subsequently since] only on the basis of Being-with does 'empathy' become possible." ${ }^{\prime 60}$ Empathy, in turn, can "provide the first ontological bridge from one's own subject, which is given proximally as alone, to the other subject." However, Heidegger admits that the process of connecting with others based on empathy "has little ground to stand on" and furthermore that "one may still be puzzled as to how Dasein's relationship to itself is thus disclosed to the Other as Other."161 The degree to which empathy with others is achieved depends on how far "one's own Dasein has understood itself at the time." This depends on "how far one's essential Being with Others has made itself transparent and has not disguised itself." ${ }^{\prime 62}$ For Dasein to be able to understand itself it must be able to summon itself and become resolute. ${ }^{63}$

The others, as a conceptual entity, are necessarily part of Dasein's world and they are involved in a wide range of public interactions based on the work they perform. These interactions are not political in the Ancient sense, meaning they are not aimed at cultivating virtue, or some good, nor do they involve political dialogue that reconciles differences. However, Dasein is able to be authentic in its relation with others and to develop empathy. Dasein is able to care and to be concerned. Heidegger does not provide a clear indication of how empathy develops. But he does maintain that if the others commit themselves to a common cause, their relationships will be authentic and characterized by empathy. The nature of this common cause is best understood through the

\footnotetext{
${ }^{60}$ Heidegger, Being and Time, 125.

${ }^{61}$ Ibid., 124.

${ }^{62}$ Ibid., 125.

${ }^{63}$ Ibid., 229.
} 
notion of resoluteness. Resoluteness is predicated on Dasein's ability to free itself from the constraints of another entity encountered in the world: 'the they.'

'The they' [das man], as a conceptual entity stands in opposition to the 'others.' 'The they' appear when 'the others' lose their autonomy and become an indistinguishable and homogeneous mass. 'The they' can stifle Dasein's possibility towards Being. Just a few examples can illustrate the extent to which 'the they' tempt, tranquilize, and alienate Dasein. ${ }^{64}$ 'The they,' Heidegger writes, noiselessly suppress every kind of priority, gloss over everything that is primordial as something well known, manipulate everything gained by struggle, cause every secret to its loose force and even unleash their own dictatorship. ${ }^{65}$ 'The they' present every judgment and decision as their own, deprive Dasein of agency and reduce Dasein to 'nobody.' And though Dasein is inauthentic amongst 'the they,' it exists amongst "'the they' because 'the they' "is an existentiale; and as a primordial phenomenon, it belongs to Dasein's positive constitution." ${ }^{66}$ The they' is a way for the 'others' to sometimes find themselves. For, as Heidegger maintains: "Proximally, it is not ' $\mathrm{I}$ ', in the sense of my own Self, that 'am', but rather the Others, whose way is that of the 'they. ${ }^{67}$

'The they' have a valuable role to play in Dasein's possibility towards Being because they provide a "pre-ontological way of interpreting its Being." ${ }^{168}$ This valuable role also has a dark side. This same pre-ontological interpretation of Being, can cause Dasein to interpret itself solely in relation to 'the they.' In

\footnotetext{
${ }^{64}$ Heidegger, Being and Time, 254.

${ }^{65}$ Ibid., 127.

${ }^{66}$ Ibid., 129.

${ }^{67}$ Tbid.

${ }^{68}$ Ibid., 130.
} 
other words, 'the they' generate a sense of Being for Dasein through language and culture. This sense of Being is inauthentic because 'the they' only relate to Dasein as an objectified entity, or thing. As Heidegger writes: "the phenomenon of the world itself gets passed over in this absorption in the world, its place taken by what is present-at-hand within-the-world, namely, Things.."${ }^{169}$ Thus, for Dasein to become authentic in its relationship to Being, it must remove itself from a common sense of Being as presence-at-hand, which 'the they' promote and experience authentic Being-One's-Self. ${ }^{70}$

Once again, Dasein can form an authentic relationship with 'others' and summon itself from being lost amongst 'the they' only if it becomes resolute. Becoming resolute requires first that Dasein acknowledges its call to conscience. This call for conscience is not well articulated in words, but rather communicated as an obscure and indefinite utterance. ${ }^{71}$ And, though inarticulate, this call for conscience is made in connection to Dasein's guilt and imposes on Dasein a sense of indebtedness. As Heidegger writes "Being-guilty does not first result from an indebtedness, but that, on the contrary, indebtedness becomes possible only 'on the basis' of a primordial Being-guilty. ${ }^{172}$ The relationship between Dasein and others is itself derived from this sense of Being-guilty; of 'owing" something or of "having something due on account. One is to give back to the Other something which the latter has a claim. ${ }^{\prime 73}$ Thus, in its daily interactions, Dasein is in a constant state of reckoning, wondering what it owes to others, what it is

${ }^{69}$ Heidegger, Being and Time, 130.

${ }^{70}$ Ibid.

${ }^{71}$ Ibid., 273.

${ }^{72}$ Ibid., 284.

${ }^{73}$ Ibid., 282. 
deprived off, what it has borrowed, what is withheld ${ }^{74}$ from it.

After Dasein experiences the call of conscience and experiences guilt in relation to others, Dasein must then claim its freedom by choosing only "one possibility" out of the many existential possibilities. ${ }^{75}$ In doing so, Dasein becomes resolute. Heidegger defines resoluteness as: "This distinctive and authentic disclosedness, which is attested in Dasein itself by its conscience - this reticent self-projection upon one's ownmost Being-guilty, in which one is ready for anxiety - we call "resoluteness." ${ }^{\text {"76 }}$ In being resolute Dasein does not free himself from the world but rather for the world: "Resoluteness, as authentic Being-one'sSelf, does not detach Dasein from its world, nor does it isolate it so that it becomes a free-floating 'I.' And how should it, when resoluteness as authentic disclosedness, is authentically nothing else than Being-in-the-world?"77 Indeed it is through this authentic being with others that Heidegger is able to address the 'free-floating' 'I' that typifies German Idealism. Since Dasein is part of the world, 'the they' do not cease to exist, but do cease to deprive Dasein of an authentic relation to Being. In Heidegger's words: "The irresoluteness of 'the they' remains dominant notwithstanding, but it cannot impugn resolute existence. ${ }^{\prime 78}$

Dasein's call for conscience can only occur after Dasein accepts its own finitude; its own death. This acceptance both frees Dasein from 'the they' and makes resoluteness possible. Heidegger writes that the encounter with death "reveals Dasein its lostness in the they-self, and brings it face to face with the possibility

\footnotetext{
${ }^{74}$ Heidegger, Being and Time, 281.

${ }^{75}$ Tbid., 285.

${ }^{76}$ Ibid., 298.

${ }^{77}$ Ibid.

${ }^{78}$ Ibid., 299.
} 
of being itself,... in an impassioned freedom towards death - a freedom which has been released from the Illusions of 'the they', and which is factical, certain of itself and anxious." chapter as well. For now, I focus on the possibility towards resoluteness that this encounter makes possible.

Death is the fundamental unknown. By encountering it, Dasein also encounters the unknown. However, death is not the only unknown. Being is also unknown to Dasein. This encounter with death opens up possibilities towards Being. These possibilities for Being were present among the 'they,' but only in their pre-ontological and inauthentic state. When facing its death, Dasein is able to appropriate those possibilities and select one among them. Heidegger writes:

The existential projection in which anticipation has been delimited, has made visible the ontological possibility of an existentiell Beingtowards-death which is authentic. Therewith, however, the possibility of Dasein's having an authentic potentiality-for-Being-a-whole emerges, but only as an ontological possibility. ${ }^{80}$

Hence, it is not Dasein that gives meaning to death. Rather, the confrontation with death and the anxiety that follows opens up possibilities for Dasein towards Being.

The ability to project an authentic possibility towards Being, however, does not necessarily belong to Dasein as singular. Heidegger is careful to point out that Dasein, as an individual, cannot, and does not, stand-alone. Dasein is not only thrown into the world, but, as we have seen, its normal condition is Being-

\footnotetext{
${ }^{79}$ Heidegger, Being and Time, 266.
}

${ }^{80}$ Ibid. 
in-the-world. When Dasein projects its possibility for the future, it does so together with others and thus engages in authentic historicality. Heidegger writes:

But if fateful Dasein, as Being-in-the-world, exits essentially in Beingwith Others, its historizing is a co-historizing and is determinative for it as destiny. This is how we designate the historizing of the community of a people. Destiny is not something that puts itself together out of individual fates, any more than Being-with-oneanother can be conceived as the occurring together of several Subjects. Our fates have already been guided in advance, in our Being with one another in the same world and in our resoluteness for definite possibilities. Only in communicating and in struggling does the power of destiny become free. Dasein's fateful destiny in and with its 'generation' goes to make up the full authentic historizing of Dasein. ${ }^{81}$

Dasein must forge a community with others based on empathy, and it must share a destiny under a common understanding of Being. ${ }^{82}$ This insight is not only found in Being and Time, it is also present in Heidegger's early writings. In these writings, he no longer invokes the concept of Dasein metaphysically but rather in the context of the German folk.

${ }^{81}$ Heidegger, Being and Time, 384.

${ }^{82}$ A more detailed account of authenticity is, I understand, present in his work is "Die Herkunft der Kunst und die Bestimmung des Denkens" in Distanz und Nahe but I was not able to find a translated copy of this article. I understand that here he attempts to explain the connection between the modern understanding of limit as something to be overcome in contrast to the Greek understanding as something to be attained. He combines the two in an understanding that since a limit is necessary for Dasein, Dasein must set such a limit itself. 


\section{Historical resoluteness}

A few years after the publication of Being and Time, Heidegger applied the language and concepts from work to the political and historical events of his time. He did so not only to better understand the transition from the Weimar Republic to Nazi rule, but also to demonstrate his support for Hitler's new regime. Heidegger eventually fell into disrepute with the Nazis. This was in part because of his views on science, and because of his disagreement with the Nazi propaganda use of biology and anthropology in Nietzsche's work. It is also true that his famous poetic line that "he who thinks greatly must err greatly" ${ }^{\prime 83}$ can, and has been invoked many times, to represent Heidegger's apology. The fact remains that Heidegger's work continues to threaten modern liberal democracies because it leaves virtually no room for diversity and political flexibility. This element of homogeneity emerges most forcefully from the notion of authentic historicizing in Heidegger's thought. Here, I focus on this notion to illustrate why the role of empathy, as envisioned by Heidegger, is dangerous if applied to the modern practice of euthanasia.

To better illustrate the meaning of authentic historicizing in Heidegger's work, let us examine some remarks from Jürgen Habermas. Habermas points out that Heidegger used Being and Time to advocate nationalism. Habermas maintains that the original meaning of Dasein in Being and Time had been singular and had therefore focused on the individual and his path towards his own death. Habermas' remark is somewhat erroneous because, at the very minimum, one

\footnotetext{
${ }^{83}$ Martin Heidegger, Poetry, Language and Thought, Translated by Albert Hofstadter (New York: Perennial Classics, 1971), 9.
} 
must concede that Dasein never can escape the world in which he is thrown. We, therefore, cannot speak of Dasein as Habermas does in terms of an "isolated individual. ${ }^{\prime 84}$

Nevertheless, I do agree with Habermas, that Heidegger did use the political reality of his time to work out certain positions, which were not well elucidated in Being and Time. ${ }^{85}$ Amongst these ambiguous positions of primary importance for this study, is what Heidegger calls 'authentic historicizing.'

In the 1930s, Heidegger phrased his support for the Nazis in the language of Being and Time. For instance, in 1933, in "The Self-Assertion of the German Universities," Heidegger writes:

...the loyalty of the teaching and student bodies awakens and becomes stronger only if there is a true and common rootedness in the tradition of the German universities. This tradition, however, only attains prestige and power, when the leaders themselves are guided by the inexorability of that spiritual order that stamps the destiny of the German people with the imprint of history. ${ }^{86}$

Given the situation in Germany at the time, this German resoluteness could only mean the coming together of all Germans. "In the future," Heidegger writes, "will flourish the threefold commitment and service of the German student body, once in the community of the people through the Labor Service; again to the honor of the nation through the Army Service; and a third in commitment to the

${ }^{84}$ Jurgen Habermas, The Philosophical Discourse of Modernity: Twelve Lectures, trans. Frederick Lawrence (Massachusetts: MIT Press Cambridge, 1987), 157.

${ }^{85}$ Habermas, The Philosophical Discourse of Modernity, 156.

${ }^{86}$ Martin Heidegger, "The Self-Assertion of the German Universities," (1933) in, German Existentialism, trans. Dagobert D. Runes (New York: The Wisdom

Library, 1965), 16. 
spiritual order of the German people through the service of learning. ${ }^{187}$ There was little left to the imagination here. This common service was to be undertaken in the political realm. It was, on one level, an assertion of freedom as selflegislation. As Heidegger writes: "to give oneself a code of laws is itself the highest form of freedom. ${ }^{\prime 88}$ This was a freedom entrusted to those understanding "the glory and the greatness of the Hitler revolution." ${ }^{189}$

Moreover, in a different speech, Heidegger states: "Doctrine and 'ideas' shall no longer govern your existence. The Fuhrer himself, and only he, is the current and future reality of Germany, and his word is your law. ${ }^{\prime \prime 0}$ As Habermas explains: "Heidegger singles out the historical existence of a nation yoked together by the Fuhrer into a collective will as the locale in which Dasein's authentic capacity to be whole is to be decided."${ }^{\prime 11}$ Being and Time thus, provided the script for speeches no longer meant to stir up individual existence, but rather the nation as a whole. ${ }^{92}$

Heidegger's brief support for the National Socialists is, of course, no secret and this study is not meant to dismiss his work based on this fact. But I do intend to point out that Being and Time is not apolitical. Consequently, Heidegger is intellectually dishonest in his "Letter on Humanism," when in response to Sartre, he tries to remove political connotations from his work. He writes: “When I speak of the 'quiet power of the possible' I do not mean the possible of a merely

${ }^{87}$ Heidegger, "The Self-Assertion of the German Universities," 19. ${ }^{88} \mathrm{Ibid}$.

${ }^{89}$ Ibid., 20.

${ }^{90}$ Martin Heidegger, "German Students," Freiburger Studentenzeigung, Nov. $3^{\text {rd }}$, 1933, In. German Existentialism, Translated by Dagobert D. Runes (New York:

The Wisdom Library, 1965), 26.

${ }^{91}$ Habermas, The Philosophical Discourse of Modernity, 157.

${ }^{92}$ Ibid., 158. 
represented possibilitas, nor potentia as the essentia of an actus of existential; rather, I mean Being itself, which in its favoring presides over thinking and hence over the essence of humanity, and that means over its relation to Being.."13 There is, of course, an engagement with Being that invites contemplation in thought (to this I shall return in subsequent chapters). However, Being and Time, taken in its entirety, also invites radical action.

The kind of action that Being and Time legitimizes involves a united people, caring and empathizing under a common historical destiny. It involves an all-encompassing political resoluteness without concession for a plurality of views. In this manner Dasein chooses one historical path and engages in authentic historizing. Furthermore, it is only under the umbrella of authentic historizing that Dasein can develop authentic relations with others based on empathy. Yet, this only can happen once the tension between different views is abolished and replaced with a uniform destiny. Under these conditions, ethics cease to challenge laws, and laws become less focused on ensuring the individual's freedom. Instead, laws become focused on ensuring homogeneity. This is, of course, the mark of a totalitarian state in which, "it is assumed that the valid law is identical with the ethics common to all. ${ }^{\prime \prime 4}$ This is a state where there is no need for politics, for politics implies difference.

In sum, while Heidegger is successful in grounding the 'free-floating I' unleashed by German Idealism into a sense of community and in infusing it with a sense of care and empathy he unleashes new problems. These problems consist

\footnotetext{
${ }^{93}$ Martin Heidegger, "Letter on Humanism," trans. David Farrell Krell, In Martin Heidegger: Basic Writings (San Francisco: HarperCollins Publishers, 1993), 220.

${ }^{94}$ Arendt, The Origins of Totalitarianism, 394.
} 
in the fact these authentic interactions in the community become subject to a common historical pursuit to which every citizen must relate in order to be authentic. If, diverging interests were to emerge, which is often the case in most communities, and a common historical destiny were not to be pursued, then, according to Heidegger, such interactions would be inauthentic. Yet, supposing diverging interests do not emerge, and supposing further that everybody follows a common historical destiny, then the kind of 'authenticity' they would attain would actually be dictatorial. Thus, as 'the others' become authentic they in fact transform into 'the they.'

The danger of 'the they' deciding 'the good death'

Returning now to the arguments for euthanasia, the creation of narrow ethical standards for judging a good life and a good death actually occurred in Nazi Germany under the banner of national unity. Germans remember these laws to this day, making it difficult to disassociate the word euthanasia from its employ by the Nazi. Hence, in part because in Germany euthanasia is associated with political killings that were justified by a system that claimed to have devised a standard according to which it could judge who was worthy to live and who was not, euthanasia is less practiced than in other countries of the Western world. And, despite the fact that Heidegger's concept of an authentic relation with others is dangerous to modern politics because it reflects totalitarian leanings, which resonate with Nazi Germany, I do believe that Heidegger's concept of 'the 
they' can, nevertheless, be instrumental in revealing the dangerous implications of modern arguments for euthanasia.

Heidegger explains that, while among "the they," Dasein is incapable of thinking about its own death because doing so would be interpreted as a sign of cowardice. As he puts it: "the 'they' [do] not permit us the courage for anxiety in the face of death." ${ }^{\prime 95}$ 'the they' tempt, tranquilize and alienate Dasein and push it into "constant fleeing in the face of death." 96 Yet, admittedly, death remains one's own because " $n]$ o one can take the Other's dying away from him." ${ }^{\text {"97 }}$ The alienation of Dasein from death becomes an alienation from itself. In the extreme, 'the they' are capable of obliterating any sense of Being, and of depriving Dasein of the possibility of contemplating Being as well as depriving it of any meaningful action. To quote Heidegger: "it 'was' always 'the they' who did it, and yet it can be said that it has been 'no one. ${ }^{98}$

A potential application of the above to the modern practice of euthanasia could take the following form. Euthanasia involves the collaboration of a medical physician prescribing lethal drugs to a patient and, occasionally, a third party administering them. On one level, the involvement of other parties makes one's decision to end his life easier because these other parties provide him with expertise. More importantly, they help legitimize the practice through their participation. In doing so, they turn what is fundamentally a difficult personal decision into a communal decision shared among family members, physicians, and, in societies where the practice is legalized, the society at-large. To put it in

\footnotetext{
${ }^{95}$ Heidegger, Being and Time, 298.

96 Ibid.

${ }^{97}$ Ibid., 284.

${ }^{98}$ Ibid., 127.
} 
Heideggerian language, for instance, a man refusing to face the anxiety accompanying death, and inauthentically fleeing from death, could ask 'the they' to bring about his or her death instead.

To restate this in reference to Dostoyevsky's Brothers Karamazov, man does not only put his freedom of conscience at the feet of the Grand Inquisitor. He places his very life at the feet of medical professionals and a non-involved third party so that they may judge whether to end it. This is a dark scenario, the kind Heidegger cautioned against when he warned that 'the they' can assimilate "the others" and deprive Dasein of any authentic being in relation to others.

\section{Concluding remarks}

The temptation to establish a standard for judging the good death based on empathy for the suffering is one that we are capable of resisting. Indeed, resisting it may very well be the only prudent approach when confronting a murderous path that has been treaded before by Nazi Germany. While it is true that euthanasia in Nazi Germany was justified as necessary for the good of the state, and thus differs from our modern understanding of it, there are clear similarities between the two. One is the belief that we can generate an efficient standard according to which we can pass a uniform and homogenous judgment on what constitutes a good death for the terminally ill. Another is the attempt to judge the good death based on empathy for the suffering because it overlooks how one has lived the whole of his life. The narrower the standard according to which euthanasia is deemed acceptable, the more expedient the process becomes. But 
by judging the good death outside the broader context of how one has lived, one overlooks the fact that the way one dies indicates also how one has lived. Thus, unless an expedient standard for judging the good death is adopted, one will continue to die as one lived, and to have what Rilke called a death of one's own.

Furthermore, it is ironic that modern arguments for euthanasia use empathy to promote the killing of those in pain, rather than using empathy to promote the soothing and healing of the suffering while they are alive. Empathy is thus sadly misused to promote the act of bringing about one's death, rather than promoting better care for the dying.

Comparing a suffering animal to a suffering human being is arguably the most offensive, and yet it has become common amongst bioethicists and people in society. "One would not allow an animal to go through what I have endured," pleaded Chantal Sébire. She is correct. One would not do so because the life of an animal is resumed to its biological existence, and therefore, to its health. In the absence of biological well-being, the lives of animals no longer have much value (our care for pets, notwithstanding). Human life, by contrast, has historically been understood in our Western philosophical and religious traditions as more than mere biological existence. It is this difference that has defined our humanity according to Ancient Greeks, Christians, and even modern thinkers.

As Joseph Pieper once argued, there is greater potential found in the word 'man' that we still preserve in our language today. For instance, it makes no sense to convince a pig to act like "a real pig." ${ }^{\text {"9 }}$ But it does make sense to call a man to his conscience by asking him to 'act like a man.' As such, we still consider

${ }^{99}$ Pieper, Joseph. An Anthology (San Francisco: Ignatius Press, 1989), 6. 
it an unjust death if one "dies like a pig." But it seems absurd to say that "a pig died like a man." This illustrates that our language about proper living and proper dying continues to preserve our humanity, even when modern practices like euthanasia threaten its demise.

The role for empathy, even as Heidegger, as a late modern, who no longer shared many if any liberal principles, envisioned it, still entails the ability to relate to others based on factors other than mere biological well-being. Sadly, modern arguments for euthanasia do not. Instead, these arguments prescribe for human beings efficient standards for judging when their lives can end and send the cruel message that only the healthy life is worth living. 


\section{Chapter 4. Life support and technological thought}

In 1995, Jean-Dominique Baudy suffered a severe stroke that left him comatose for 20 days. Though he eventually awoke and recovered his cognitive abilities, his entire body remained paralyzed, with the exception of his left eye. With help from a transcriber, and only the use of his left eye, Baudy was able to write a book titled, The Diving Bell and the Butterfly, in which he tried to make sense of his ordeal. However, before he began writing this book, his first words, gathered together under the duress of many a blink of an eye, were: "Je veux mourir."

Baudy's case is one of many that illustrate man's ability to penetrate into the mysterious realm that lies between life and death. Technology has rendered the time previously reserved for contemplating and surrendering to death accessible to man. In doing so, it has forced man to gaze upon this threshold between life and death and to do what he does best: debate its meaning.

The many lawsuits filed involving life-support issues that began with Karen Quinlan in 1976, and which continue to this day with the more recent and famous cases of Terry Schiavo in Florida and Samuel Golubchuk in Manitoba, testify that man must now legally reckon with this in-between stage of life. These legal debates are themselves the result of deeper moral conundrums. It is no coincidence that in Quinlan's case, her parents' strong Catholic beliefs were taken into consideration before ceding her guardianship over to her father. Along similar lines, in the cases of Terry Schiavo and Samuel Golubchuk, religious consideration divided public opinion, and even the medical community. 
In this chapter, I explore philosophical insights that can help us to better understand debates about life support decisions. I engage Heidegger's work on technology and I attempt to relate it to the current debates over life support. I concur with Heidegger's work on technology - that technology can take many forms, none of which are necessarily dangerous - and I argue, based on his work, but which I complement with the work of philosopher A.N. Whitehead and bioethicist Albert Jonsen, that technological thought, especially among medical doctors, is always necessarily amoral. At the limit, it can even be murderous.

Technological thought is itself an ambiguous term and I am aware of its many connotations. For the purpose of this chapter, I define technological thought as thought loyal to efficiency and expediency and which, even though it sprang from the scientific method, preserves only an oversimplified, and often bureaucratized version of its scientific roots. It is thought committed to knowledge derived from induction. Finally, even if it is accurate, it is not moderated or guided by any moral principles, be they philosophical, religious, or even insight derived from experience.

Methodologically, I embark on an overview of the scientific method. However, I do not engage the vast amount of literature on the philosophy of science, but rather focus on certain aspects of it, including assumptions, moods, and even elements of Greek Drama present in modern science that play a defining role in forming technological thought. My intention here is two-fold. I first intend to illustrate the source of some problems emerging from the application of technological thought to patients receiving life support. Second, I intend to show that Heidegger's work contains an avenue for questioning 
technology through politics and that life support technology is already providing the setting for this questioning.

\section{Overview of life support in the Intensive Care Unit (ICU)}

Before analyzing the implications of life support technology, I must begin by explaining in greater detail the current interaction occurring between patients, families, and doctors in the Intensive Care Unit of a hospital where decisions about life support are being made. Life support is summarily defined as a procedure of keeping someone suffering from critical injuries or illness alive through the use of technology. This technology includes machines that take over bodily functions, such as: nutrition and hydration, mechanical ventilation, heart and lung bypass, and urinary catheterization. The impact of this technology cannot be overstated. Life support technology literally stops people from dying. The benefits of life support are evident, as when a person suffering from a critical injury is kept alive until he can recover control of his body and begin the healing process.

The most controversial use of life support is for palliative care purposes. ${ }^{1}$ Here, life support technology is used to sustain life despite strong medical evidence that the patient's full recovery is improbable. Under these conditions, a person is said to be 'stuck with life.' When this occurs, the patient, his family, and the medical doctors face several ethical dilemmas, including the need to

\footnotetext{
${ }^{1}$ John Luce and Ann Alpers, "Legal Aspects of Withholding and Withdrawing Life Support from Critically Ill Patients in the United states and Providing Palliative Care to Them," Respiratory and Critical Care Medicine 162 (Dec 2000): $2029-2023$.
} 
answer questions: "can treatment be discontinued?"; "what is the difference between discontinuing treatment and homicide?"; and "who is most suitable to make this decision?" Most of these decisions are made in the Intensive Care Unit of the hospital and, as Douglas Walton rightly asserted, "they are amongst the most formidable challenges for any study of ethics in medicine." ${ }^{2}$ To make matters more difficult, once admitted to the ICU, neither the patient nor the family are usually in a good frame of mind to make these decisions. Moreover, these decisions can have long lasting traumatic effects.

The setting in which these life and death decisions are made is equally important. Unlike the palliative ward of a hospital, where there is little technology around and where it usually takes the form of pain-killers, often available on demand, technology is ubiquitous in the ICU. Machines, including ventilators, nutrition, hydration, and endotracheal tubes, dialysis equipment, external pacemakers, and sometimes even an electroencephalograph (EEG) around the patient's head to monitor neural activity, all surround the patient in the ICU.

The history of the ICU can be traced back to Florence Nightingale, who, in 1854, triaged the severely wounded from the rest of the patients during the Crimean War. This helped reduce British causalities from $40 \%$ to $2 \%$. The practice spread to Europe and to North America and, in conjunction with an increase in medical technology, led to the routine use of a wide range of equipment to monitor patients, and even to medically induce their comas. The

${ }^{2}$ Douglas N. Walton, Ethics of Withdrawal of Life-Support: Case Studies on Decision Making in Intensive Care (London, UK: Greenwood Press., 1983), 32. 
use of this equipment has created the need for an army of trained nurses and doctors to operate it while they tend to their patients.

As expected, intensive care is extremely costly. For this reason, admission to the ICU is often an issue of contention in hospitals. One of the main criteria is a belief among specialists that the patient will recover quickly from his critical condition, given these units have a limited number of beds. More often then not, another decisive factor, especially in the United States, is the willingness of an insurance company to cover the costs. Provided these conditions are met, and a patient is admitted to the ICU, his or her life may be saved. The benefits of the ICU and of life support technology are therefore tremendous. That said, of course, if the patient's condition does not improve, then the decision to remove him from ICU and discontinue his life support becomes very controversial.

Although this is a difficult decision to make, it is not a decision made by one person alone. Rather, it often involves significant discussion and debate between numerous parties. It is a decision that oscillates depending on the patient's health. For instance, a patient whose prognosis appears to be hopeless following a stroke may suddenly improve. Then the decision to remove him from life-support may thus change in a matter of minutes. To complicate already complicated matters, tests may reveal that the same patient is in an early stage of lung cancer and that he could be too weak to undergo chemo or radiation therapy. Once again, the decision is pending on further discussion. Decisions made in the ICU can therefore be best understood as a longitudinal sequence of events subject to change, rather than as a set of constant circumstances.

Moreover, if we assume that a patient's condition does not improve and that he is in a persistent vegetative (or non-cognitive) state, then further tests are 
required to determine if he is brain dead. More debates thus ensue based on EEG readings as to whether or not the patient can be considered brain dead based on his neurological activity. Despite various attempts to devise a clear and all encompassing definition of death, these definitions, as Hans Jonas rightly observed, "are tainted with the suspicion of expediency." ${ }^{\prime 3}$ A grey area always remains, and, as Walton argued, "until these attempts at classification and diagnosis are better researched, a lack of precision must remain attached to the umbrella term of "persistent vegetative state. ${ }^{\text {" }}$

Indeed this lack of precision still applies to the current situation because the debate over brain death diagnosis continues. Guidelines are periodically updated. Nevertheless, the hope many physicians hold is to eliminate this gray area for good. The most recent guidelines on diagnosing brain death were published in $2010 .^{5}$ Here, Dr. Bernat commented that: "The new recommendations are encouraging uniformity and thoroughness among institutions. ${ }^{\prime \prime}$ However, as it currently stands, the threshold between life and death is difficult to delineate and the debate is currently settled through the traditional practice of dialogue between physicians, patient, and family members. It is a difficult discussion to make: one with dangerous consequences that can amount to ending a life. There is the temptation to eliminate this process

\footnotetext{
${ }^{3}$ Hans Jonas, "The Right to Die," The Hastings Center Report 8 (1978): 36.

${ }^{4}$ Douglas N. Walton, Ethics of Withdrawal of Life-Support: Case Studies on Decision Making in Intensive Care (London, UK: Greenwood Press, 1983), 51.

${ }^{5}$ Eelco F.M. Wijdicks et al., "Evidence-based guideline update: Determining brain death in adults," Neurology 74 (2010): 1911-1918. http://www.neurology.org/cgi/content/full/74/23/1911 ${ }^{6}$ Allison Gandey, "New Brain Death Guidelines Issued," Medscape Medical News, Accessed June 10, 2010. http://www.medscape.com/viewarticle/723342
} 
in favor of a clear standard, but this only raises concerns about physicians declaring patients dead on paper so they can harvest their organs. For this reason Hans Jones argues that the Papal ruling - "when deep unconsciousness is judged to be permanent, extraordinary means to maintain life are not obligatory. They can be terminated and the patient allowed to die" - should go a step further and states that the patient "ought to be terminated because the patient ought to be allowed to die; stoppage of the sustaining treatment should be mandatory, not just permitted." In sum these decisions involve intense debates and it is to these debates that I turn to next.

\section{Making decisions in the ICU}

Asclepius, ${ }^{8}$ the story goes, was hired to retrieve from death a man whose life had already been forfeited to the gods. In doing so, he transgressed divine decree and cured the man through intensive means. As punishment, Zeus struck him down. Asclepius' moral decisions continue to resonate in the Intensive Care Units of modern hospitals. While issues like euthanasia and suicide are discussed extensively in the literature on bioethics, the way in which decisions about life support are being made, or should be made, is poorly covered. Most authors

\footnotetext{
${ }^{7}$ Jonas, "The Right to Die," 36.

${ }^{8}$ As an aside, there is also an analogy between medicine and political rule illustrated by both Plato (407d-410a) and Aristotle. As Aristotle, himself the son of a physician, wrote: "to know how actions must be performed and distributions made in order to be just is a harder task than to know what makes men healthy. It is rather like medicine (1137a11)." The reference to medicine by early Greek philosophers indicates that they understood medicine in more holistic terms rather than as merely an art of curing diseases. It also indicates that they conceived medicine as a practice that must be bound to nature and committed to justice.
} 
expediently assume that, in certain situations, patients ought to be allowed to die while disregarding hardships and practical difficulties these decisions actually entail. In this regard, Richard A. McCormick's observation that "the ethical discussion of these truly terrifying decisions has been less then fully satisfactory" ${ }^{\prime 9}$ holds true even 30 years later.

Despite the paucity in the literature, it is easy to identify salient factors and actors involved in making decisions to withhold life support. If a patient is capable of making an informed decision, then, legally, the principle of autonomy stands. In this case, he can decide for himself the course of action he desires based on his understanding of available options. His moral beliefs take precedence over other factors based on his personal autonomy. However, if the patient is unconscious, then the principle of autonomy is questioned. The patient's autonomous decision-making is often undercut and transferred to someone else, often the person next in kin, when unconscious. As an example, in the case of Keren Quinland, her father assumed the responsibility and nobody challenged the court ruling. In the case of Terri Schiavo, things became complicated when her parents challenged her husband's custody over her. Here, the case escalated into a nation-wide debate between Washington and the State of Florida, making a local police official remark in jest whether the state of Florida had enough officers to hold off the National Guard. ${ }^{10}$ In both cases,

\footnotetext{
${ }^{9}$ Richard A. McCormick, "To Save or Let Die: the Dilemma of Modern Medicine," in Contemporary Issues in Bioethics, ed. Tom L. Beauchamp and LeRoy Walters Belmont, (California: Wadsworth Publishing Company, Inc., 1978), 332. ${ }^{10}$ Chris Hawke, "Report: State Tried Schiavo Grab" CBS Newws, Accessed March 26, 2005. $\underline{\mathrm{ml}}$ http://www.cbsnews.com/stories/2005/03/26/national/main683300.sht
} 
though family members acted on behalf of the patient, they knew the patient and they could therefore envision what the patient would have wanted.

However, when the patients are children or the mentally challenged, this principle cannot be invoked at all. In such cases, decisions become more paternalistic. Sometimes, in addition to family members and physicians, a third party is brought in to ensure that the decision is still made in the interest of the patient. There are other cases where a patient is unconscious and no family members can take over this responsibility. Here, the physician and the hospital staff become responsible for deciding whether the patient's life support ought to be discontinued and his life ended. Although, as Walton points out, the trend in both Canada and the United States is towards patient autonomy and away from paternalism, ${ }^{11}$ it is unfortunately not always possible.

To help people make these difficult decisions, some bioethicists recommend the need for basic guidelines. McCormick, for instance, put forth a list of criteria intended to balance "sheer concretism and dogmatism." First, McCormick recommends 'Facing Responsibility', by which he means the physician's advice should be readily available to facilitate informed decisions and, given modern medicine's proficiency at keeping patients alive, quality of life arguments should be advanced. In McCromick's words: "This is quality-oflife judgment. And we fear it. And certainly we should. But with increase power goes increased responsibility. Since we have the power, we must face the responsibility."12

${ }^{11}$ Walton, Ethics of Withdrawal of Life-Support, 200.

${ }^{12}$ McCormick, "To Save or Let Die: the Dilemma of Modern Medicine," 332. 
Second, McCromick advances the criteria of 'A relative good,' by which he means finding a middle way between the Judeo-Christian belief in death as an absolute bad and life an absolute good, which would entail that "life is indeed a basic and precious good, but a good to be preserved precisely as the condition of other values." The third criteria he recommends is 'Quality of life,' predicated on the individual's ability to foster and sustain human relationships. As he writes: "since these other values cluster around and are rooted in human relationship, it seems to follow that life is a value to be preserved only insofar as it contains some potentiality for human relationship."13 Needless to point out that ambiguity looms large over these guidelines. Indeed, the debate around Schiavo's case also involved the fact that she seemed to be smiling, which implied a higher cognitive ability. Despite their aim these guidelines, in effect, generate further controversies about their feasibility.

Leon Kass, meanwhile, also addresses the issue of life support, but does so peripherally. His argument hinges on the belief that "human dignity and the sanctity of life not only are compatible, but if rightly understood, they go hand in hand. ${ }^{14} \mathrm{He}$ further argues that dignity in dying is not a feature that machines can take away from a human being because dignity does not rest with the machines in the first place. While I find Leon Kass' argument compelling, he does not address the issue of life support directly. Instead, he implies one should be kept on life support indefinitely and that letting them die does not apply to terminating life support. Kass articulates his provision for special cases as follows: "I also know that when hearts break and people can stand it no longer,

\footnotetext{
${ }^{13}$ McCormick, "To Save or Let Die: the Dilemma of Modern Medicine," 332-335.

${ }^{14}$ Kass, Life Liberty and the Defense of Dignity, 234.
} 
mercy killing will happen, and I think we should be prepared to excuse it - as we generally do - when it occurs in this way. ${ }^{15}$ It is true that terminating life support often amounts to causing a patient's death. But is this mercy killing, or is it letting them die? Kass does not provide a clear answer. If terminating life support to someone who can only be kept alive in this fashion and for decades amounts to homicide, then Kass is more life-affirming than the Pope. I do not have an argument against Kass other than to note that it is an advice that is hard to enforce in light of clear evidence that the patient would rather be allowed to die, or that no recovery would ever be possible and only a slow deterioration of all vital functions would occur, amounting to an indefinite extension of the dying process.

This ambiguity that typifies arguments about life support is, in part, also rooted in the way decisions about life support are being made in society. Many bioethicists worry about the possibility of abuse on a scale never before encountered. These decisions risk destroying the very fabric of our political system, and Kass is himself aware of this. He writes: "should we choose to become technical dispensers of death, we will not only be abandoning our loved ones and our duty to care: we will exacerbate the worst tendencies of modern life, embracing technicism and 'humaneness' where encouragement and humanity are both required and sorely lacking."16

Unlike most bioethicists examining life support decisions only in passing, Douglas N. Walton commits an entire book to these decisions. While Kass impresses with his determination to sustain human life at all costs and in all

\footnotetext{
${ }^{15}$ Ibid., 255.

${ }^{16}$ Kass, Life Liberty and the Defense of Dignity, 256.
} 
circumstances, Walton places his trust in our political nature. Walton rejects Holmes' argument about dividing the decision over life support between facts and values by attributing facts to knowledgeable physicians while attributing values to the patient and their families. Walton argues that the certitude of fact in the context of life support is lacking, and that to maintain the assumption that such certitude is even possible can only exacerbate an already difficult decision. He invokes a study by Crane that shows how physicians themselves do not have a unanimous understanding of what constitutes fact. For example, eighty-nine percent of neurosurgeons said that they would operate on a patient affected only physically by cerebral hematoma, while only fifty-five percent would operate if the patient's mental functioning was also affected. ${ }^{17}$

This inability among medical professionals to clearly distinguish fact from value leads Walton to contemplate traditional practices of decision-making. Walton argues that

The process of decision making in the problematic types of cases .... takes place by means of what may be called a game. I do not mean 'game' in the sense of any frivolous or contestive activity, the way this term is commonly used. Rather, by a game I mean an interpersonal interchange between two or more parties. The medium of the game is a decision to pursue one of two possible alternatives. ${ }^{18}$

In more concrete terms, Walton returns to a quasi-Aristotelian conceptualization of politics. He explains that "Aristotle's name for this sort of game was dialectic,

${ }^{17}$ Walton, Ethics of Withdrawal of Life-Support, 208.

${ }^{18}$ Ibid., 211. 
meaning a series of questions and answers in a dialogical interchange designed to elicit the participants' reasons for their opposed views." ${ }^{19}$

It takes the tragic conditions associated with life support technology to remind us of politics in the older sense. Thus, 'rules of the game,' as expressed by Walton in this new tragic setting, are stated as follows:

The game can be frustrated if one participant treats it as a debate or quarrel and adopts sophisms, or policies of deceit or distraction. If he persists, the game will break down and must then be treated as an adversary process by the other participants as well in order to forestall the continuance of a one-sided and unproductive delaying action or filibuster. $^{20}$

For Walton, in the ICU, political dialectic would be an open communication between physician and patient. If the patient is incapacitated, then this dialectic would be between physicians and the family or guardian. In this setting, the questions asked are serious and could include: "will the patient live or die?"; "should he be treated intensively?"; and "what can this outcome be?" Decisions taken can have serious consequences. As such, more than one person is involved in the final decision rather than a family member, often lacking medical expertise or a medical physician, lacking insight into the life and moral views of the patient. This way the guilt that inevitably accompanies the decision to discontinue loved ones from life support is less severe because it is arrived at through a clearer understanding of the situation.

\footnotetext{
${ }^{19}$ Walton, Ethics of Withdrawal of Life-Support, 212.

${ }^{20}$ Ibid.
} 
While Walton's approach is sound and it aims at a just course of action, it does have shortcomings. Aristotle himself paid significant attention to the proper education of citizens, for, it is only with a virtuous citizenry that this political interaction can make physicians, family members, and patients content with their decisions. Despite its limitations, this scenario remains the best possible in its ability to mediate between technical expertise and ethics, while ensuring moral choices are made even under strenuous circumstances.

While this section describes how political decisions are made in the Intensive Care Unit, larger questions remain that need to be addressed to better understand life support technology. Among those is: "what is the nature or essence of life support technology?" In as far as it is still technology, the dilemmas that emerge from life support are part of a larger debate concerning technology: Therefore, the philosophical resources that can explain technology in general can also help elucidate the nature of life support.

\section{Ancient drama in scientific thought}

Before addressing the literature on technology and its roots in the scientific method, I would like to take a round about way and attribute its origins to Greek Drama, rather than, as it is commonly done, to thinkers such as Francis Bacon and René Descartes. By the seventeenth century, modern science, already armored with Machiavelli from a few centuries earlier, sprang into modernity. It had fought its way with the Christians and stood poised for the future. It embodied both a way - the scientific method - and a destination: scientific truth. 
But its creation was not ex nihilo. Its deeper roots were in the Western philosophical tradition that occasionally embarrassed it. Its roots are, according to Whitehead, and indirectly also to Heidegger, not only Platonic logos, but also Greek Drama.

This does not necessarily mean that modern scientists epitomize the tragic hero, but rather the belief in a tragic universe: a universe that, although anthropocentric, is shared with the Gods. Though heroes are often on a quest to confront the limits of this universe through strength, courage, and/or intelligence, they inevitably fail, and suffer, and justice does not always prevail. And, while heroes come to understand that they were fated, they also paradoxically, accept responsibly for their fate and assert themselves as moral agents rather than victims.

Whitehead argues this point in greater detail. He maintains that the pilgrim fathers of scientific imagination are the great tragedians Aeschylus, Sophocles, Euripides, and that the element of fate from Greek Tragedy became the order of nature in modern thought. The fascination with heroic incidents that verify the nature of a fated universe for the Greeks was transferred to our epoch and became a pursuit of scientific experiments. Whitehead illustrates this transformation from the old fascination with heroic deeds into a fascination with scientific experiments with a personal anecdote:

It was my good fortune to be present at the meeting of the Royal Society in London when the Astronomer Royal for England announced that photographic plates of the famous eclipse, as measured by his colleagues in Greenwich Observatory, had verified the prediction of Einstein that rays of light are bent as they pass in the 
neighborhood of the sun. The whole atmosphere of tense interest was exactly that of the Greek drama: we were the chorus commenting on the decree of destiny as disclosed in the development of a supreme incident. There was dramatic quality in the very staging: - the traditional ceremonial, and in the background the picture of Newton to remind us that the greatest of scientific generalizations was now, after more than two centuries, to receive its first modification. Nor was the personal interest wanting: a great adventure in thought had at length come safe to shore. ${ }^{21}$

The solemn and remorseless admission about the inevitability of destiny generated for the Greeks a sense of "futility of escape," made evident by the drama. This same remorselessness pervades scientific thought, evidenced by the way laws of physics are perceived as the decrees of fate. ${ }^{22}$ While the Greek dramaturges were not themselves the inventors of this order, but rather its propagators through the literary tradition, their work imprinted this particular sense of order unto the imagination of a classical civilization. ${ }^{23}$ It now persists in modern times.

A relationship between art, in general, and technology is also evident in Heidegger's thought. In his essay on technology, Heidegger establishes this relationship by pointing out the etymological connection between techne and artisanship. Heidegger envisions art as having an almost redeeming quality of disclosing the world.

${ }^{21}$ A. N. Whitehead, Science and the Modern World (New York: Mentor Books, 1949) 11.

${ }^{22}$ Tbid.

${ }^{23}$ Whitehead, Science and the Modern World, 12. 
In Basic Questions of Philosophy, ${ }^{24}$ Heidegger also describes the role of art as informing Greek philosophical thought. Here, he attributes to art the ability to create a mood. While in Being and Time, 'Angst' is the primary and almost transhistorical mood, making it possible for Dasein to confront its finitude, after 1929 Heidegger begins to attribute a historical character to moods. He names four distinct moods in the history of Western Thought: awe and astonishment typify the Greeks; certainty is the basic mood for the Cartesian age; and horror and boredom represents the technological humanity that characterizes our time. And though apparently antithetical, both of these moods "reveal," as Zimmerman points out, "a meaninglessness of things in a world from which the gods have fled." ${ }^{25}$

Of particular importance to this study are awe and astonishment. These moods, Heidegger argues, typify the Ancient Greeks and they resonate with Aristotelian thought, particularly with Aristotle's belief that tragedy should inspire pity and fear and that philosophy begins with wonder. While awe shares with fear in its arresting capacity, astonishment has a certain kinship with wonder. Despite the difficulty of tracing awe and astonishment directly to Aristotle, it is indeed easy to trace it to tragedy. Greek tragedy, and the epic poetry from which it sprang, impart on audiences an arresting fear mixed with disbelief. Thus, the epic tradition and Greek drama instilled awe and astonishment as moods for the Ancient Greeks.

According to Heidegger's argument, one can even speculate that these moods acted as muses guiding Socrates' quest for philosophical truth. On some

\footnotetext{
${ }^{24}$ Martin Heidegger, Basic Questions of Philosophy: Selected "Problems" of "Logic," (Bloomington: Indiana University Press, 1994).

${ }^{25}$ Michael E. Zimmerman, Heideger's Confrontation with Modernity: Theology, Politics and Art (Indiana: Indiana University Press, 1990), 115.
} 
level, The Republic remains true to these moods if one considers the numerous occasions where Socrates' interlocutors are in awe of his arguments. Consider the interlocutors' awe at the 'three waves' and their astonishment at being comforted with the thought of a good beyond the Olympians, beyond Being. In Glaucon's words "Apollo, what demonic excess!"26

A study meant to trace emotions or moods though history is necessarily problematic. The Republic was, after all, designed to affect different souls differently, while always towards a greater good. These limitations notwithstanding, my point is that in spite of the objectivity claimed by science and the absoluteness of 'Being' in Plato, there was an element of drama that became utilized by philosophy and later incorporated in the scientific method. This explains why scientists pursue their work with passion and continue to be driven by a quest that resonates with an older quest for glory and a philosophical quest for truth. It also explains why scientists are able to embark on their quest without doubting its importance or questioning basic assumptions about the 'stubborn facts' on which they base their conclusions.

\section{The scientific method and the meaning of facts}

It is to those stubborn facts that we turn to next. Despite Heidegger's strong criticism of the scientific method, it is imperative to recall that his greatest criticism is not directed at science qua science, but at petrified thought that no longer allows for a possibility towards Being. His tone is, of course, grave. But it

\footnotetext{
${ }^{26}$ Plato, The Republic, trans. Allen Bloom (New York: Basic Books, 1991), 509c.
} 
would be too swift a generalization to call his thought anti-scientific. I would argue that, despite their differences, Heidegger shares more with Whitehead in his understanding of science than it appears at first glance. To be sure, Whitehead sees in Francis Bacon, one of the founders of modern science, an element of doubt, whereas Heidegger regards Bacon as the beginning of a blatant assertion of the materialistic school. They also differ in that Whitehead believes the scientific pursuit is salvageable, whereas Heidegger is more skeptical about this possibility.

Yet, aside from these disagreements, the two philosophers share the belief that the inductive approach, on which the scientific method was founded, helped increase technological advancement at the cost of narrowing the ability to think in broader metaphysical terms. To phrase it differently, the inductive method typifying the scientific method is only made possible if the deductive approach that contemplates the possibility of a larger order in the universe is assumed. In Whitehead's own words:

Induction presupposes metaphysics. In other words, it rests upon an antecedent rationalism. You cannot have a rational justification for your appeal to history till your metaphysics has assured you that there is a history to appeal to; and likewise your conjectures as to the future presupposes some basis of knowledge that here is a future already subject to some determination. The difficulty is to make sense of either of these ideas. But unless you have done so, you have made nonsense of induction. ${ }^{27}$

${ }^{27}$ Whitehead, Science and the Modern World, 45. 
Along similar lines, Heidegger maintains that modern science, and by extension modern technology, dangerously misrepresents the Ancient Greek pursuit of truth. Modern science for Heidegger, abandoned its contemplative and metaphysical roots. It has become committed to the rule of enframing and of transforming all nature, including man's, into standing reserves. In Heidegger's words: "the rule of enframing threatens man with the possibility that it could be

- denied to him to enter into a more original revealing and hence to experience the call to a primordial truth. ${ }^{\prime 28}$ As such, the danger science poses to us moderns is not in the form of technology qua machineries, or even the intrusiveness of the laboratory experiment, but manifests itself as the elimination of paths that had once been conducive to metaphysical thought.

Moreover, Heidegger and Whitehead agree on the role mathematics has assumed in society for representing facts. Whitehead writes: "nothing is more impressive than the fact that as mathematics withdrew increasingly into the upper regions of ever greater extremes of abstract thought, it returned back to earth with corresponding growth of importance for the analysis of concrete facts." ${ }^{29}$ Compare this with Heidegger's claim in Being and Time that: "the pragmatic character of mathematical natural science does not lie in it exactitude or in the fact that it is binding for 'everyman;' it consists rather in the fact that the entities which it takes as its theme are discovered in it in the only way in which entities can be discovered - by the prior projection of their state of Being. ${ }^{\prime \prime 30}$ In

\footnotetext{
${ }^{28}$ Martin Heidegger, "The Question Concerning Technology," in Basic Writings, ed. \& trans. David Farrell Krell (San Francisco: Harper Collins Publishers, 1993), 333.

${ }^{29}$ Whitehead, Science and the Modern World, 34.

${ }^{30}$ Heidegger, Being and Time, 362.
} 
short, observation of the natural world has become, due to the scientific method, mediated by mathematics.

Here, I do not intend to provide a comprehensive overview of the history of science. There is, of course, a vast body of literature on the philosophy of science. I draw from this parallel that the expediency with which the scientific method has assumed facts collapses in the case of life support technology. The work of Heidegger and Whitehead thus becomes most helpful because it provides a language for re-engaging truth even if it is no longer rooted in the 'stubborn facts' that would expedite decisions pertaining to life support.

This disagreement on facts becomes acutely political when, as Crane's study shows, medical physicians themselves interpret the same reading of an EEG differently. For this reason, these readings are occasionally debated in our courts, as in the case of Terry Schiavo, for instance. In order to address this gray area, often, the testimony of more than one physician is required for diagnosing someone as "brain dead" based on an EEG reading. This is because machines, by their nature, can only project a pre-existing belief and lack the kind of specificity required to label someone as dead. A machine can be programmed to detect and record the electric activity in the brain and the EEG does exactly that. Indeed, it does so very well. But the EEG cannot, by itself, assign meaning to this output beyond what it is programmed to indicate. An EEG that records no activity in the brain can be coded to deliver a written output of 'brain dead,' but this kind of certitude cannot reassure a close family member, who intuitively knows a machine only delivers what its programming allows.

This is when a physician's expertise in interpreting the EEG becomes imperative. For this reason, while some prestigious jobs such as surgeon may be 
replaced in the future by machines that can exceed human accuracy, these machines will not be capable of also engaging in politics. For, whatever the nature of technology may be, it is not political. And, as mentioned earlier, the greatest danger Heidegger outlines with technology does not take the form of machines, but rather of human beings who limit their thinking by mimicking machines. It is to this danger that I turn to next.

\section{Modern medicine and technological thought}

Heidegger is often misunderstood to be idiotically anti-technology. But, if this were true, then his later work on technology would have completely contradicted his earlier analysis of the notion of equipment in Being and Time. In fact, I argue, Being and Time and The Question Concerning Technology are consistent on the level of method, and simply differ in the thought required to reveal their essence. Put simply, the essence of both equipment and technology needs to be revealed or disclosed; however, while equipment can be disclosed through its absence or its "un-ready-to-hand," mistakenly placed belief in 'truth.' Thus, what is required for contemplating the essence of technology is not its mere absence, but the contemplation of technology's claim to truth.

Heidegger argues that, while equipment forms the world of things around us, he never differentiates simple objects from technologically advanced ones. A telephone or a radio, for instance, can be called equipment just like a random

$\overline{{ }^{31} \text { Heidegger, Being and Time, }} 73$. 
chair or a table, despite their obvious differences in the amount of technique required to build and operate them. The essence of equipment is disclosed when equipment is missing: the essence of a pencil is clearest when one is on the phone and needs to write down a phone number, but lacks a pencil. In Heidegger's words:

When something ready-to-hand is found missing, though its everyday presence has been so obvious that we have never taken any notice of it, this makes a break in those referential contexts which circumspection discovers. Our circumspection comes up against emptiness, and now sees for the first time what it the missing article was ready-to-hand with, and what it was ready-to hand for. The environment announces itself fresh. ${ }^{32}$

By the same token, the essence of a telephone is made obvious when the telephone no longer functions and one needs it to make a phone call. Heidegger never uses the example of a telephone or a radio because, to him, a telephone or a radio is fundamentally no different than a pencil.

Years later, in the Question Concerning Technology, when Heidegger argues that the essence of technology is enframing, he is applying the same logic. He argues:

On the other hand all those things that are so familiar to us are standard parts of assembly, such as rods, pistons, and chassis, belong to the technological. The assembly itself, however, together with the aforementioned stock parts, fall within the sphere of technological

\footnotetext{
${ }^{32}$ Heidegger, Being and Time, 75.
} 
activity. Such activity always merely responds to the challenge of enframing, but it never comprises enframing itself or brings it about. ${ }^{33}$ While certain mechanical objects can cease to function, technology in its totality, never ceases to function. For this reason, a much needed telephone that is broken may disclose the essence of a telephone, but not the essence of technology as a whole.

For the essence of technology to be disclosed in its entirety, something radical must occur: a dangerous possibility. For entities to be disclosed, a "circumspective concern" ${ }^{34}$ must present itself. In the case of technology, a sense of danger must be present to make enframing visible. ${ }^{35}$ When this danger is present, the essence of technology manifests itself. It is an essence that embodies a misleading truth that aims at controlling nature rather than at contemplating it in order to discover it. Moreover, it is not only control over nature qua nature but also human nature. The greatest danger of not questioning technology is that of turning human beings into 'standing reserves,' or into beings ready to be ordered and controlled. In the absence of this danger, the thought that comes to typify modernity continues to be technological, and its virtue, if such a word is even appropriate, would be technological itself (i.e. it would be an existence typified by efficiency).

Albert Jonsen's explanation about the danger technological thought holds for modern medicine is most insightful. His book presents an overview of the historical transformations of the relationship between physicians and patients and he concludes with a section on modern ethics. Jonsen attributes the

${ }^{33}$ Martin Heidegger, "The Question Concerning Technology," 326.

${ }^{34}$ Heidegger, Being and Time, 76.

${ }^{35}$ Heidegger, "The Question Concerning Technology," 333. 
beginning of technological thought in medicine to Bentham, as well as to an increased reliance on statistics. According to Jonsen, "technology in medicine refers to a complex of medical thinking, medical devices, and coordination of medical workers. It is the logic of diagnosis and therapy, and the applications of skills and maneuvers that may be called techniques." ${ }^{\prime 36}$ Reliance on these techniques and on statistical thought in modern medicine holds enormous benefits for patients. Treatment, for instance, is no longer based on random experiences or the untested intuitions of the doctor.

However, the application of these techniques in a systematic and statistically orientated manner ${ }^{37}$ produces a number of ethical problems. ${ }^{38}$ First, since statistical certitude is limited and based on probability, decisions made under these conditions depend on "the risk of being wrong that physicians are willing to tolerate." For physicians who have a low tolerance for risk they generate the "do everything" mentality to ensure the physician's safety ground. ${ }^{39}$ The second problem resulting from technological thought is the availability of a multitude of techniques ready-made and ready at hand, but which leaves no room for human ingenuity. As one clinician admonished his residents: "don't do something, just stand there." ${ }^{40}$ Finally, this same thought generates a mindless application of drugs and machines that produce results, but lack the ability to question the value of those results. Antibiotics, for instance, cure pneumonia, but technological thought does not ask if pneumonia should always be cured.

\footnotetext{
${ }^{36}$ Albert R. Jonsen, The New Medicine and the Old Ethics (Boston: Harvard University Press, 1991), 115.

${ }^{37}$ Bentham also founded the Statistics Society before his death.

${ }^{38}$ Jonsen, The New Medicine and the Old Ethics, 113.

${ }^{39}$ Ibid., 115.

${ }^{40}$ Ibid., 116.
} 
Patients terminally ill with bone cancer, for instance, might wish to die of pneumonia. Technology, Jonsen conclude: "is what it is and should remain what it is. It is a human achievement of extraordinary ingenuity and utility that is quite distinct from the human accomplishment of ethical values. ${ }^{\prime 41}$

The application of this technological thought to life support is terrifying because it eliminates the gray area of decision-making that Walton argues should be reserved for political discussion and replaces it with a false sense of certitude. To illustrate this point metaphorically, I would like to return to Persephone's descent into the underworld. According to the myth, Hades forcefully kidnapped Persephone and forced her into the underworld. Once there, he was able to keep her because he tricked her into eating the food of the Underworld. That she was still able to unite with the Olympians for most of the year should not generate amazement: the Gods always found ways around death. For us mortals, however, the descent is categorical.

However, though this descent is categorical, the threshold between life and death is still a mystery. By analogy, the incapacitation that befalls many of us before we die is often violent and technological thought, can 'trick' the dying person into death. This is because, as discussed earlier, technology in the intensive care unit comes to mediate the transition between life and death. Technology in the form of machines may not be inherently dangerous, but blind trust in these machines can be. The greatest danger lies in having blind faith in a machine or a hospital procedure that dictates when one should die. Under these circumstances, technology would come to mediate the threshold between life and death. Or, to continue the analogy, technology would become Hermes.

${ }^{41}$ Jonsen, The New Medicine and the Old Ethics, 119. 
However, this new technological Hermes would not only bring people to the underworld, it would also give them the hope that they could earn more time and give them the belief that they are acting in good conscience when bringing about someone's death. In a world typified by technological thought alone, the bond between Persephone and Demeter, which held in it the older mystery of seasons, of biology, and of procreation, would bring Demeter into Hades; but not Persephone up to Mount Olympus. Metaphors aside, this would correspond to Kass' dark scenario of a citizenry that is a "dispenser of death."

\section{The possibility for politics}

Despite raising the dreadful scenario emerging from the application of technological thought to life support, I do see another, more optimistic scenario emerging out of Heidegger's work. The danger concerning technology can also be addressed in politics, as opposed to simply art, as Heidegger maintains in The Question Concerning Technology. Heidegger's own work demonstrates how early thought about Being was not the product of philosophical reason, but rather emerged in a culture that revolved around the polis, and therefore around politics.

In his search for the beginnings of thought about 'Being,' Heidegger returned to the Ancient Greeks and to the pre-Socratics. His work on Parmenides is part of this quest. In it, he discusses the relationship between politics, truth, and Being. He writes: "if à $\lambda \dot{\eta} \theta \varepsilon$ ca as unconcealedness determines all beings in their presence (and that means, for the Greeks, precisely in their 
Being), then certainly the no $\lambda_{\iota}$ too, and it above all, has to stand within the domain of this determination by $\dot{\alpha} \lambda \hat{\eta} \theta \varepsilon ı$, provided the $\pi \mathrm{o} \lambda \iota \varsigma$ does indeed name that in which the humanity of the Greeks has the center of its Being. ${ }^{\prime 2}$ Heidegger continues: "this place, lets beings appear in their Being and show the totality of their condition. ${ }^{\prime \prime 3}$ This same insight is taken up again in The Essence of Human Freedom. Here Heidegger articulates this relation even more clearly. He writes: "the Greeks saw truth primarily as pertaining to beings themselves." ${ }^{\text {"4 }}$ Thus, the city, understood as the public place where men interact, is also the place where they reveal themselves and their essence to others, their being as it were. It is through politics, to use more colloquial terms, that their true character is revealed and that they become known for who they are.

The city is also the only place, as Heidegger maintains, where tragedy could be born. This is because tragedy represents an artistic expression that is itself, like politics, revolving around what is hidden and what is tragically disclosed about man's essence. In Heidegger's words: "the possibility, and the necessity, of 'tragedy' itself has its single source in the conflictual essence of $\dot{\alpha} \lambda \eta \theta^{\prime} \varepsilon ı{ }^{\prime \prime}{ }^{\prime 45}$ The truth about being, emerging from Greek tragedy, is the same truth emerging from Greek politics. It is a truth typified by a search for man's being: one meant to reveal man's character. It is not a truth to which man must conform, but rather a truth that man himself reveals and also discovers about himself and others in the process.

\footnotetext{
${ }^{42}$ Martin Heidegger, Parmenides, trans. André Schuwer and Richard Rojcewicz (Bloomington: Indiana University Press, 1992), 89.

${ }^{43}$ Ibid.

${ }^{44}$ Martin Heidegger, The Essence of Human Freedom. Trans. Ted Sadler (New York: Continuum, 2005), 74.

${ }^{45}$ Heidegger, Parmenides, 90.
} 
This kind of truth, Heidegger maintains, has been lost. It is lost because, in the Western history of philosophy, truth has been progressively removed form man and placed outside of him so that "the essence of truth," he writes, "has been transformed into certitude. ${ }^{146}$ Sadly, as truth has distanced itself from man, it came to represent a source of authority. During the modern era, to this connotation of authority was added one of power. Finally, Heidegger argues, truth has been adopted by the modern state, thus obliterating the possibility of politics in the Greek sense and replacing them with power. ${ }^{47}$ For this reason, modern man has a public space where the state dictates through power and no avenue remains for discovering his essence though tragedy or politics.

Regarding the issue of life support, the dangers of understanding truth as certitude, combined with the power of the modern state, are acute. There are no second chances in these situations because life support can only be discontinued once. And since the person is often our next of kin, perhaps an elder or a loved one, the kind of personal dramas that unfold under those circumstances are, for each of us, of tremendous consequences.

These new ICU dramas are real, and often, they do not have the cathartic function of Greek drama because they carry only ultimatums. Moreover, in the ICU, the certitude assumed by science comes in direct contact with the older element of drama as the tragic hero, who is the patient under life support. The setting is, of course much altered. For, while in the Ancient Greek drama the universe was the stage on which the individual acted, in the ICU, the setting is reminiscent of a laboratory. Yet, under those constraining circumstances, the

\footnotetext{
${ }^{46}$ Heidegger, Parmenides, 91.

${ }^{47}$ Ibid.,
} 
need for action is acute, while the path towards the right decision is largely unknown.

And yet, 'Have not these morally difficult decisions already forced us to question the kind of certitude that technology unleashed?' As mentioned above, there is an ongoing public debate about whether certain men and women on life support should be kept on or disconnected from life support. The issue is also affecting many at the personal level, as loved-ones, especially the elderly, increasingly become beneficiaries of life support technology. These are all difficult choices. But as long as they remain difficult, we will be forced to face them courageously, to ponder them wisely, and to act in such a way that the truth about ourselves, immerging from our actions, will not terrify us. Finally, this difficult confrontation with technology shows that the kind of questioning concerning technology that Heidegger began can be carried out in politics and thus remain bound to reason, rather than 'liberated' into the chaos of artistic expression.

\section{Concluding remarks}

Heidegger's refusal to contemplate the possibility of politics is on the one hand rooted in the general discontent with politics that typified the 1930s, and which he fully shared. On another, it is also rooted in his philosophical observations that, in the history of thought, truth went from being contemplative in nature to being associated with power, and then used as a source of oppression. For these reasons, despite the grave danger that life support technology poses, Heidegger 
would disagree that politics in this modern context could help us in our confrontation with modern technology.

Yet, his disagreement notwithstanding, this chapter also reveals a 'darker' side of politics that is often ignored. Namely that politics is not a mere engagement in speech, but that it can also be a confrontation with the unknown that holds dramatic possibilities. In short, by being political, one does not merely demonstrate a proclivity to engage in arguments, but also understands that he can be shown to be wrong and also to have made wrong choices. In the case of life support technology these choices, it is true, can also be fatal. However, by failing to realize that these choices are ours to make we risk becoming victims of technological thought. 


\section{Chapter 5. Physical immortality and the control of time}

One question that has preoccupied the minds of men throughout history has been "If men die, shall they still live in some afterlife?" We have long assumed that the answer lies only beyond this side of the grave. Major advancements in technology, however, may soon render this question obsolete, and replace it with a new one: "If men don't die, shall they still live?" This question captures the traditional human struggle for immortality, while launching us towards future possibilities. And, it can also bring us back to early thought, which asked, not only if men should live, but also how they should live.

I begin this chapter with a brief summary of the literature on immortality. Some predictions made by scientists and social scientists have yet to be confirmed. However, I use their arguments here because too often in history, futuristic predictions that seemed unlikely to materialize have indeed occurred. For instance, a mere five years before the fist atomic bomb was dropped over Hiroshima, Albert Einstein stated that man would never poses the technology required to create such a destructive weapon. Likewise, even if immortality continues to elude us, it will still remain the focus of scientific research for generations to come. Furthermore, in the field of bioethics, immortality is being routinely discussed as a not so distant possibility with serious political and ethical implications.

Physical immortality implies tampering with human biology, the organism, the cells that form the organism, and the DNA found within these 
cells. From a biological perspective, immortality involves the complete transformation of human beings at all three levels. Activists for immortality often assume that, if man were to live forever, nothing would change except for his gain in time and his avoidance of aging and death.

However, from a purely biological perspective, this assumption is flawed. It is often geneticists and biologists, who, despite working towards it, also warn against the prospect of immortality. Social scientists, engineers and fictional writers, meanwhile, often favor the idea. From the perspective of human evolution, immortal human beings would lack the ability to evolve through natural selection, as well as the ability to adapt to changes in the environment. As such, they would risk being killed en masse by any new virus or change in the environment. From a biological perspective, the price for human immortality might therefore be, as Beneke argues, the death of the species.

Immortality activists, by contrast, see matters differently. For most of them, immortality would mark the end of human bondage to nature's 'cruel' laws and their substitution with human laws. It would mark the beginning of a new age in which man would master his own evolution.

Not surprisingly, the ethical and political implications of immortality branch out in numerous directions. I will outline some of the debates in this study, but I will focus primarily on the conceptual approach to time that makes immortality possible: namely, the belief that time can or should be mastered.

In doing so, I return to the question I asked early: "If men don't die shall they still live?" Answers to this question can only be speculative, since immortality in the here and now remains elusive. It may forever remain this way, or it may become a reality we reckon with in the future. Here, I assume the 
latter. I do so because reputable scientists attest to its possibility and their research is seldom short of funding. In fact, biomedical research averages 90 billion dollars a year in the US alone. Immortality creates a new set of ethical questions superceding those concerning end of life issues discussed in previous chapters.

Heidegger's work on temporality is most instrumental in conceptualizing some of the implications of immortality. According to Heidegger, man's ability to recognize his finitude by accepting his imminent death also allows him to become resolute towards the possibility of Being. In other words, facing the possibility of one's own death grants one the freedom to become intimately aware of his existence and to act and to think without neglecting finitude as part of his being. Though man can become many things, he can do so because he is a mortal being. It is not his mortality per say that grants him this ability, but rather the consciousness of his mortality that opens up possibilities for being. With this in mind, the question becomes: 'Can immortal human beings still relate to their finitude?'

I argue this question can be answered by imagining two scenarios. In the first, immortal human beings will no longer be bound by their finitude and will consequently not develop a consciousness about their mortality. In the second scenario - since immortal human beings are sheltered from aging, but not from accidents or crime because they can still be physically killed - the prospect of death would be more dramatic than ever before because it would be seen as avoidable. In this second scenario, immortal human beings would experience more anxiety about death than us mortals do today and they would risk living in constant fear of dying. 
Both scenarios imply mastery of time: something only omnipotent beings can possess. Such beings would have the power to will their own future. They would, however, lose the ability to think of time as attention to living well ${ }^{1}$ and to 'grow wise' in time.

The physical immortality promised by biomedical technology, I argue, would generate a false sense that time can be mastered. I root this argument in Heidegger's work on technology, to demonstrate why immortality would obliterate Being by generating the illusion that technology can help us control time. Furthermore, I show that Heidegger's astute remarks on how the Cartesian principle, that rests behind technology and causes us to loose sight of Being, is also applicable to Heidegger's own concept of authentic temporality. I therefore propose to use Heidegger's work on technology to criticize his earlier concept of authentic temporality. Indeed the projection into the future that typifies authentic temporality is uncannily similar to the projection of hypothesis onto nature that typifies the scientific method. Authentic temporality, in other words, can be understood as a means of controlling time, the way technology aims at controlling nature. In the end, physical immortality would result in the same obliteration of Being that Heidegger feared and warned against in his work on technology.

\section{Immortal beings of an endangered species}

\footnotetext{
${ }^{1}$ Plato, The Republic, 490b.
} 
Though the prospect of drastically extending life expectancy still remains only a possibility in theory, we are now seeing hints that it may soon become a reality. In this section, I relate some of the strongest factors that may one day lead us closer to eternal life. Before doing so, I reiterate how scientists are generally modest in their predictions about the extension of life expectancy and often caution against activism that preserves only a veneer of science and is rooted only in the blind hope that immortality will be achieved. Factors that may extend our lives significantly include: nutrition supplements and exercise, stem cell research, organ growth, gene therapy, and deciphering telomeres. These are just a few, considering the vast amount of literature on nutrition and anti-aging alone. My intention here is to provide only an overview, and not a detailed account, of the advancements that may lead to immortality.

Nutrition supplements and exercise

Though nutritious food and exercise are important factors for health, there is an extensive list of supplements for those wanting to live longer. These often include additional hormones, such as growth hormone. ${ }^{2}$ This is because growth hormone has been shown to help children grow taller as well as prevent aging and help regenerate muscle and skin tone in adults. ${ }^{3}$ Not surprisingly, growth hormone is also prescribed by most anti-aging and immortality advocates. This, in turn, has given raise to an illegal market for hormones because physicians are

\footnotetext{
${ }^{2}$ Ray Kurzweil and Terry Grossman, Fantastic Voyage: Live Long Enough to Live Forever (New York: Rodale Inc, 2004), 280-291.

${ }^{3}$ Ben Bova, Immortality: How the Science is Extending Your Life Span-And Changing the World (New York: Avon Book, Inc., 1998), 29-47.
} 
often reluctant to prescribe them to people in good health. ${ }^{4}$ Physical exercise, meanwhile, can increase the amount of antibodies and make an organism better fit to fight diseases. Low impact exercises such as weight lifting can also increase growth hormone levels naturally.

Indeed the list of foods and exercises that can delay aging is too vast to recount here. However, neither nutritional supplements nor exercise contribute directly to immortality. They merely help delay the aging process and decrease the likelihood of illness.

Stem cell research and organ growth

Despite heated ethical debates over embryonic stem cell research at the turn of this past century, stem cell researchers have made tremendous advancements in both the United States and throughout the world. The brief ban on embryonic stem cell research in the United States has prompted American scientists to channel their efforts at obtaining stem cells from regular body cells. They have indeed been successful and these laboratory-generated stem cells have become referred to as 'pluripotent stem cells. ${ }^{5}$ These cells have eliminated the controversy surrounding embryonic cells, since no embryos are destroyed to make them. They have also allowed for the future possibility of ensuring adult individuals a constant supply of stem cells with their own DNA.

\footnotetext{
${ }^{4}$ British Broadcasting Corporation, Visions of the Future: The Biotech Revolution, hosted by Michio Kaku, Accessed: July 2010. http://video.google.com/videoplay?docid $=-5040988246744133463$ \# ${ }_{5}^{5}$ Monya Baker, "Adult cells reprogrammed to pluripotency, without tumors." Nature Reports Stem Cells. 2007-12-06. Accessed: October 3, 2010. http://www.nature.com/stemcells/2007/0712/071206/full/stemcells.2007.124. $\underline{\mathrm{html}}$
} 
The importance of stem cells to medicine cannot be overstated. They make possible the re-growth of any cell in the body, be it, a blood, nerve, muscle, or skin cell. ${ }^{6}$ Simply put, this technology promises to make it possible for individuals to have a bank of personal organs at their disposal.

Stem cells can also cure future diseases, as entrepreneurs have begun to observe. Many now offer new parents the option of freezing the stem cells found in the umbilical cord of their new-born babies. This may eventually shelter future generations from some diseases and from organ failure; though still not from actual aging and death.

\section{Gene therapy and deciphering telomeres}

Gene therapy is the most recent development in medicine and arguably the most revolutionary. It involves inserting genes directly into an individual's cell to change their DNA and thereby eliminate genetic diseases. It has been focused mostly on diseases caused by single-gene effects, such as muscular dystrophy, hemophilia, or cystic fibrosis. But researchers also have began using it to treat cancer.

One way of inserting these genes into cells is through viruses. Specifically, the procedure involves first empting the DNA strand of a virus and then replacing it with healthy genes. The genetically modified virus is then inserted into the body. Gene therapy is still in its infancy. But like most new forms of biotechnology, it benefits from a wealth of new discoveries about DNA and the completion of the genome project, which has mapped human chromosomes.

\footnotetext{
${ }^{6}$ Bova, Immortality, 172.
} 
One of these discoveries has been the presence of telomeres. Telomeres are regions at the end of each chromosome that protect the chromosome. With each cell division, the telomeres wear down. When they wear down entirely, the cell dies. If the wearing down of telomeres is shown to actually cause aging, rather than being merely correlated with it, then preventing telomeres from wearing down may be the key to ensuring the immortality of cells.

Interestingly, there is a type of cell that lives forever: the cancerous cell. The telomeres of cancer cells never deteriorate irrespective of how many times the cell divides. This is the reason why cancer cells multiply so rapidly and form tumors. Consequently, immortal cells are currently considered bad news for an organism. But, anti-aging researchers hope to replicate the cancer cells' telomeres resistance to aging and one day applying it to healthy cells to prevent them from wearing down.

This, of course, raises a number of questions: 'Are telomeres meant to protect us from cells that can divide forever and that can become cancerous tumors?' Or: 'Are cancer cells' telomeres a window of possibility into expanding our cells' life indefinitely?' Either way, for now, research on immortal cells implies research on cancer cells and cancer research is never short of funding. Many anti-aging researchers and immortality advocates hope that the knowledge gained from cancer cells will one day unravel the mystery of aging. Once unraveled, they believe biotechnology will lead to the perpetual replication of healthy cells and, by extension, physical immortality.

\footnotetext{
${ }^{7}$ Mark Benecke, The Dream of Eternal Life: biomedicine, aging, and immortality, trans. Richard Rubenstein (New York: Columbia University Press, 2002), 107.
} 
All these discoveries will have a direct impact on the ongoing process of human evolution. From an evolutionary perspective, we are the product of continuous adaptation to the environment, a process that began millions of years ago. This adaptation to nature has been the cause of enormous casualties along the way. Whenever, a new virus appears or a change in the environment occurs, millions of human beings die before others can develop immunity. Death is the price we have paid for the survival of our species. Regarded from this brutal perspective, the possibility of immortality is beginning to emerge as means of saving lives, and millions of them. Not surprisingly, advocates for immortality often use this argument to advance their cause.

However, the kind of salvation on this side of the grave for which they advocate has serious problems. If immortality does indeed become a reality, it will hinder rather than help our ability to adapt to the environment. This ability to adapt is the very foundation of human evolution. And, on this foundation, rests our future. Sexual reproduction helps ensure we adapt and this adaptive process continues with every passing generation through the paring of new gene combinations. These, in turn, produce new qualities and traits. A species comprised of immortal beings, if it were to exist, would no longer be able to adapt. Consequently, immortal human beings would risk being killed en masse by microbes or viruses or by environmental changes from which evolution would otherwise protect at least some of us mortal beings. Immortality, as Benecke argued, "would mean the final death of the species."

\footnotetext{
${ }^{8}$ Benecke, The Dream of Eternal Life, 170.
} 


\section{Is immortality a good in itself?}

Immortality activists, especially their most popular representative Aubrey de Grey, challenge the aforementioned arguments against immortality. De Grey is a computer scientist by training and a self-taught biologist who is dedicating his life to the cause of brining about immortality. His focus is on Strategies for Engineering Negligible Senescence (SENS). In 2005 he co-founded the SENS Foundation, a non-profit organization based in California. De Grey's response to evolution theory is in part consistent with the orthodox view. He does agree that sexual reproduction is the means by which nature is able to ensure the survival of genes. However, he argues that aging and death are a negative externality of evolution. Specifically, even though it is more resource efficient for an organism to die after reproduction than it is for it to continue living, aging per se is not a product of evolution, but rather of evolutionary neglect. Evolution, he believes, is in fact indifferent to whether genes survive in one individual or are passed on by the individual to his offspring over generations.

Aubrey de Grey's prediction of the future is rather bold. He asserts that, provided there are no environmental catastrophes or total wars, we will witness an exponential life expansion by up to 1000 years. ${ }^{9}$ In fact, he believes the first person to live to the age of 150 is currently alive somewhere in the world today. This is not to say that people will no longer be subject to diseases, but rather that medical science will be able to preempt diseases and rejuvenate the organisms before aging and diseases occur.

9 Aubrey De Grey, "The War on Aging" in The Scientific Conquest of Death: Essays on Infinite Life Spans (Buenos Aires: The Immortality Institute, 2004), 31. 
Adding to the controversy are de Grey's claims that his arguments are entirely scientific. To test his claim, in 2006, MIT's Technological Review launched an open invitation to show that SENS was "unworthy of learned debate". The price offered to the winner was $\$ 10,000$, which the SENS Foundation promptly doubled. Estep et al. came closest to winning, but the jury did not find their case conclusive and thus awarded them only half of the prize. The jury ruled that SENS's arguments supporting immortality were based more on speculation than on scientific evidence, and that the evidence they used had been derived from early phases of research and thus could not yet be properly evaluated. They did not, however, dismiss SENS as "unworthy of learned debate." Even more interesting, Estep et al., who came the closest to dismissing de Grey, donated their prize to the American Federation of Aging Research and thus legitimized the cause of expanding the human life span. ${ }^{10}$

The moral argument for immortality is also controversial. Immortality activists base their arguments on the association between aging and disease. Since we think of diseases as evils that must be destroyed, and we invest significant time and resources in curing or eliminating them altogether, it follows for some that we ought to be consistent and treat death the same way. From this perspective, modern medicine is committed to working towards achieving immortality because it struggled to eliminate disease and postpone the effects of aging.

${ }^{10}$ Jason Pontin, "Is Defeating Aging Only a Dream," in Technological Review, July 11, 2006, Accessed July 1, 2010.

http://www.technologyreview.com/sens/ 
This existing commitment to life, combined with the potential unleashed by new technologies, has raised hopes for immortality and attracted serious activists to the cause. De Grey's arguments are particularly important here, not because they are well rooted in science, but because they represent a radical expression of an existing and well-financed trend in the developed world.

Like Aubrey de Grey, Ray Kurzweil is a computer scientist that devotes significant time and effort to raising awareness about the prospects of immortality. He has an impressive record as a futurist and he is well known for his predictions about the future based on exponential, rather than linear, time. Kurzweil argues that, due to our hunter and gatherer evolutionary heritage, our brains are accustomed to predicting events in linear time, such as the movement of an animal, however rapid, running either toward us or away from us. Technology, however, advances exponentially and our predictions thus often miss the mark. In his book The Age of Intelligent Machines, written between 19861989 and later published in 1990, Kurzweil applied his theory to the spread of the Internet, the demise of the Soviet Union, and the first computer to win against a human master at chess. His predictions were accurate then, and his record at predicting the future has continued to improve.

Kurzweil is also a strong proponent of immortality. He published three books on the topic: The 10\% Solution for a Healthy Life; Fantastic Voyage: Live Long Enough to Live Forever, and Transcend: Nine Steps to Living Well Forever. In them, he advocates daily doses of supplements from protein to hormones to healthy foods complete with food recipes. Kurzweil's thoughts on death resonate strongly with many immortality proponents: 
Until recently there was no conceivable way to cheat death, so our philosophies rationalized death as an actually good thing. 'Death gives meaning to life' is an age-old adage, but in our view death does exactly the opposite. It is a great robber of relationships, knowledge, wisdom and skills, all the things we can do with our lives - that gives life meaning. ${ }^{11}$

Though we seldom encounter this kind of blunt expression in support for immortality among non-activists, the desire for immortality is nevertheless present. This desire has been given various religious and artistic expressions over time. Legendary examples include, for instance, Gilgamesh, whose entire life was driven almost entirely by his fear of death and by his desire to live forever. Thus, aside from the exaggerated hope immortality activists place on science, I believe they express an old and deeply rooted human desire. A desire, moreover, which will not be silenced by arguments mounted against it; only postponed until further possibilities arise that make it more probable.

The desire for immortality notwithstanding, there are cogent arguments against it: (albeit arguments advocates such as Kurzweil would easily dismiss as atavistic and belonging to a time when death had to be rationalized because no other possibility existed). From a more practical perspective, a serious problem with immortality would be overpopulation and the scarcity of resources. Aubrey De Grey contends that human beings who become immortal would have to consider, as a society, the manner in which they will approach reproduction. These kinds of choices could unleash a moral nightmare if, for instance, for every

${ }^{11}$ Ray Kurzweil and Terry Grossman, Transcend: Nine steps to living well forever (New York: Rodale Inc., 2009), 400. 
new-born baby, another human being was forced to die to balance the population. Moreover, what if the rich would pay the poor and their families to die in their place. A high price indeed would be paid for immortality!

There would be many other issues to consider if immortality became a reality. Immortality would trigger serious changes and require serious adjustments to our ways of life at virtually every level, including changes to the family unit ${ }^{12}$, to our religious beliefs, to employment, to retirement, to our political and economic structure, and likely to many other aspects, of our lives that we are not yet able to foresee. However, the more immediate question is not whether these issues could be resolved, but if, however strong the desire for immortality might be, and however, close we may be to the possibility of eternal life, we could think of ways in which immortality could hinder rather than help us to live well.

Leon Kass makes a strong argument not just for mortality, but also its desirability. ${ }^{13} \mathrm{He}$ argues that immortality would increase neither our interest in life, nor our level of aspiration, nor beauty or love, nor would it make us less virtuous and moral. A professional tennis player, he argues, who could play tennis for say an additionally 25 years would not necessarily enjoy it $25 \%$ more.

A mythological example of the effects of immortality are, Kass argues, the Olympian Gods, who were rather superficial spectators of mortal men's aspirations, but lacked any aspirations of their own. Immortality would also affect art, since art itself springs from our desire to immortalize and preserve for

${ }^{12}$ On a dark-humorous note Jonathan Swift's story Voyage to Glubbdubdrib describes a people who are immortal but eternally aging. In order not to add to their sorrows the custom is to dissolve their marriage after 100 years.

${ }^{13}$ Kass, Life Liberty and the Defense of Dignity, 25. 
future generations a sense of what makes our lives beautiful. If men became immortal, they would lose the desire to preserve the beautiful by immortalizing it in art. Finally, with regard to virtue, Kass argues that immortals could not be noble because they would lose the meaning of absolute sacrifice not just in battle, but in action. It is this sprit of sacrifice that makes us aware of a life that is no longer spent preoccupied with mere survival.

Kass also makes a more subtle argument against immortality. He recognizes that human beings have longed for it since the beginning of time and that many religions throughout the world have promised it. But Kass contends that this old and more abstract form of immortality had nothing to do with the physical form of immortality sought today. In fact, it was a longing for a different type of existence altogether: an existence that was not only free from the physical and spiritual pain of human suffering, but also one that promised a reconciliation with a greater whole. This promise is encountered in philosophy beginning with Plato. Socrates' calm before death, for instance, is rooted in his belief that, while the body is subject to change, decay, and eventually death, the soul is of a different nature. While alive, the body provides the soul with the necessary means of attaining wisdom and thus a window into the possibility of permanence. The religious promise of immortality, meanwhile, is also rooted in a similar kind of longing removed from pain that the body and soul endure in the physical world and for a life lived in the proximity of God. Thus, the kind of immortality that biomedical research promises is not related to the spiritual understanding of immortality. Consequently this immortality would not shelter us from disappointment and would not make us belong to a greater whole. It 
will only give us more time here on earth. Life would not become any easier; only longer.

The kinds of changes physical immortality would prompt in society may be far-reaching, but they may not be as positive as immortality activists hope. Indeed, a far less glamorous image of our future will also emerge if we contemplate the meaning of physical immortality not only from the perspective of the relation of man with a greater whole, as Kass did, but from the perspective of man relation to time.

\section{Time as presence}

The prospect of physical immortality raises another important question: "If men don't die, how will they relate to time?" Even the most optimistic arguments for immortality contend that men could still be killed. Thus, the kind of immortality they foresee is one in which men would be eternally dependent on new biomedical discoveries to prolong their time on Earth.

In light of this, I now engage Heidegger's work on time to show that immortality would entail the transformation of one's finite time into an eternal, but impersonal time: a time that would belong to 'the they.' Moreover, this engagement will also reveal that Heidegger's understanding of time, especially his emphasis on the future, is liable to the same dangers posed by modern science and technology; namely that it can eclipse Being. Dasein's projection into the future is similar to the very process involved in the scientific method, which projects hypotheses onto nature. Authentic temporality, in other words, can act 
as a way of controlling time the same way technology aims at controlling nature. Both can relegate Being to oblivion.

Heidegger's major work, Being and Time, engages the notion of 'Being' and 'time' all throughout. However, this does not mean that Heidegger clarifies these concepts beyond the need for debate. It is more accurate to see Heidegger's work as raising more questions about 'Being' and 'time' then providing answers. Here, I use Heidegger's understanding of time holistically despite the fact that his thought changed in later years. In these later works, Heidegger emphasized poetry and language more than he did in his earlier works, where he emphasized historical resoluteness. Yet, despite these changes, the core understanding of authentic temporality, which is an approach to time that emphasizes the future, and on which both poetry and language as well as historical action rest, did not suffer any alterations.

Furthermore, though Heidegger envisioned writing an additional final section in Being and Time, to better elucidate the meaning of temporality, he never did finish this section, generating the impression that perhaps temporality, exposes the limits of his phenomenology. Nevertheless, despite the confusion surrounding 'Being' and 'time,' a basic relation between them can be established. According to Heidegger, "the essence of Being is time."14 And, 'Being,' having never been properly defined, and unconceivable as an entity, nor derived from other concepts and which is often assumed, ${ }^{15}$ is also the very purpose of Heidegger's work. He asks about "Being" through Dasein, an entity he creates for

${ }^{14}$ Martin Heidegger, Hegel's Phenomenology of Spirit, trans. Parvis Emad and Kenneth Maly (Indiana: Indiana University Press, 1988), 145.

${ }^{15}$ Heidegger, Being and Time, 4. 
this very purpose ${ }^{16}$ This entity can only ask about Being while it is in the present. Thus, any question Dasein asks will always have the character of time.

Every question ever asked has time imprinted on it. Take, for instance, the most mundane question: "What is for dinner?" This question automatically places the one posing it between the time dinner is served and the time dinner is anticipated. Not all questions imply anticipation. Some questions imply only presence. Take the question "what is a tree?" This question implies time as here and now without it having any direct connection to the future or the past. It places the one asking this question in the present, or the 'now.'

Along similar lines, the question: "What is Being?" implies "now," a presence. As Heidegger writes: "From the dawn of Western-European thinking until today, Being means the same as presenting. Presenting, presence speaks of the present." ${ }^{\prime 17}$ Since man knows he will die, the question of Being comes to denote, for any human being asking it, a sense of future anticipation. In other words, the question places the one asking it in the present and implies a time when the person will no longer be able to ask this question himself. Thus, when Heidegger explains that the essence of Being is time, he does not mean it in a universal sense, but rather in an experiential one. Otherwise stated, if we come to understand how a clock works, or how distance divided by speed gives us a value for time, or how time comes to behave differently at speeds approaching the speed of light, we do not come to understand the essence of Being. The time that we measure, or which we understand as a "concept in itself," has nothing to do with the kind of time that indicates our experiential relation to time.

\footnotetext{
${ }^{16}$ Heidegger, Being and Time, 7.

${ }^{17}$ Martin Heidegger, On Time and Being, trans. Joan Stambough (New York: Harper and Row Publishers., 1972), 2.
} 
This is, in fact, the point where Heidegger separates his thought most clearly from his mentor Edmund Husserl. Husserl, a mathematician by training, attempted to build a bridge between experienced time and 'objective' time, or what Heidegger called a "scientific philosophy."18 Heidegger never did. Instead, Heidegger attempted to show that we measure time, however accurately, only because we have an existential relation to it in the first place. ${ }^{19}$ The question about Being will therefore always and necessarily imply a sense of presence, past and future: a sense of time. This sense of time is also referred to as temporality, defined as "the way in which Being and its modes and characteristics have their meaning determined primordially in terms of time ${ }^{\prime 20}$

Heidegger describes the temporality surrounding the question of Being with such emotional gravity that it generates as much debate as the question of Being itself did. While he never mentions emotions, such as love or pride, in conjunction with Being, anxiety, fear, and dread play a prominent role and generate a sense of mystery surrounding Being. Moreover, Being and Time is artistically structured to build up suspense leading up to those feelings, thereby bestowing on Being an additional sense of gravity.

\section{Resolute time and Christian Influences}

Adding to this existential gravity are ambiguous Christian undertones that often surface in Heidegger's writing. Heidegger vehemently denies any Christian

\footnotetext{
${ }^{18}$ Martin Heidegger, History of the Concept of Time, trans. Theodore Kisiel (Bloomington: Indiana UP, 1985), 23.

${ }^{19}$ Tbid., 108-114.

${ }^{20}$ Heidegger, Being and Time, 19.
} 
influence on his thought and he explicitly states that his thought has nothing to say about the after-life or God. But his Christian studies, particularly his $\mathrm{PhD}$ dissertation on medieval theologian Duns Scotus, and his early Catholic upbringing, did nonetheless leave an impression on his thought.

Temporality, he once said, reminded him of the toiling of bells in his hometown, Messkrich, where, as a young child, as part of his church duties, he would ring the bells. ${ }^{21}$ In 1920, in a course on The Phenomenology of Religious Experience, Heidegger discussed The First Epistle of St. Paul to the Thessalonians in conjunction with temporality. He argued that the Christian relation to parousia, which marks the end of time in principle, also calls the Christians to a permanent readiness for immanence. He writes: "'Christian religiosity lives temporality.' It is a time without its own order and demarcations. One cannot encounter this temporality in some sort of objective concept of time. The when is in no way objectively graspable." ${ }^{22}$ The life of an early Christian is a life, as Dastur points out, that "remains delivered over to an indeterminate future and to the unmasterable character of time; it situates time, considered as a whole, less in the chronos then in the kairos, in the opportune moment, the moment of decision."23 As such, the Christian life is a life in which one is acutely aware of the present and lives in a constant expectation of the future. It is also a life that places far less emphasis on the past.

However, progressively, this life became altered by the penetration of Platonic and Aristotelian concepts in Christian thought. Heidegger writes:

${ }^{21}$ Rudiger Safranski, Martin Heidegger: Between Good and Evil, (Cambridge: Harvard University Press, 1998), 7.

${ }^{22}$ Ibid., 73.

${ }^{23}$ Françoise Dastur, Heidegger and the Question of Time, trans. Fançois Raffoul and David Pettigrew (New York: Humanity Books, 1999), 4. 
The meaning of this temporality is also fundamental for factical life experience, as well as for problems such as that of the eternity of God. In the medieval period these problems were no longer grasped originally, following the penetration of Platonic-Aristotelian philosophy into Christianity, and today's speculation which speaks of

God increases the chaos. The pinnacle of the error is reached today in projecting onto God the concept of validity. ${ }^{2425}$

Heidegger engages in a similar philosophic 'return' to the past to re-discover an early Christian approach to time, he used to trace the origin of Being among the pre-Socratics. In the case of time, Heidegger argues that the early Christians experienced parusia primarily as presence and resolute anticipation. This does not mean that Heidegger advocates a return to an early Christian experience of temporality, any more then he advocates a return to pre-Socratic thought. Rather, Heidegger's philosophical contemplation of the beginnings of 'Being' and 'Time' is meant to enable us to better understand the present.

Yet, this kind of search for authentic temporality does enable Christian thinkers to see in Heidegger's work a search for an authentic Christian life. For example, at the invitation of theologian, Rudolf Karl Bultmann, Heidegger lectured on "The Concept of Time." In this lecture he specified that he would focus on the 'human.' But as is often the case, he talked about the human in such

${ }^{24}$ This can be further elaborated based on his work on The Essence of Truth. Here he argues that truth came to be associated with creation, creation with the reality of the world, and reality with material truth. (119)

${ }^{25}$ Martin Heidegger, The Phenomenology of Religious Life, trans. Matthias Fritsch and Jennifer Anna Gosetti-Ferencei (Bloomington: Indiana University Press, 2004), 73. 
obscure terms that Bultmann had little difficulty reading his own theological views into it. ${ }^{26}$ Yet, this does not make Heidegger a Christian thinker.

Heidegger does not share the Christian, nor the Ancient pursuit for a higher order from which men can derive meaning for their lives. Also, while it is true that death is present in both Christian and Platonic thought, these traditions advocate a triumph over death either through faith and God's mercy or through thought. Heidegger, by contrast, makes death the center of his thought; though not with the intention of overcoming it, but with the aim of adopting it as the necessary path towards authentic temporality.

It could also be added, as a criticism, that Heidegger ignores the fact that the early Christian relation to time as presence was made possible by faith, and that the analysis of it as mere experience, devoid of the believers' relation to God, is rather superficial; a criticism valid not only of Heidegger, but of existentialism in general. In short, the neglect of metaphysical beliefs that guide experience and the focus on experience alone deprives the actual experience of meaning and ritual of its connection to the immanent. This is a limitation existentialists are often aware of and nonetheless assume willingly. In Heidegger's case, however, this problem is exacerbated by the kind of search for 'Being' and 'time' he proposes, which has powerful metaphysical origins and is more prescriptive in nature.

In sum, Heidegger is not satisfied with outlining the limits of experience in the here and now, but rather intensely preoccupied with the possibility of transcending them. Because existentialism has neither the language, nor the content, to engage with transcendence, the allusions to transcendence in ${ }^{26}$ Safranski, Martin Heidegger, 135. 
Heidegger's work give readers the impression that Heidegger is himself a metaphysician.

Heidegger's argument for authentic temporality further contributes to this sense that his phenomenology marks a return to metaphysics. Yet, this is not fundamentally the case. This point will become salient in this chapter because the absence of metaphysical arguments in Heidegger's phenomenology makes his work particularly suitable for tackling immortality from the perspective of experience in the here and now.

\section{Dasein's resoluteness: a future to be mastered}

The most politically charged and dangerous elements of Heidegger's thought revolve around his understanding of resoluteness and authenticity. Despite the moral overtones associated with his use of the word authenticity, Heidegger does clarify that the fall away from authenticity has "nothing to do with morality and ethics or the like. ${ }^{27}$ Rather, authenticity, he argues, "must be understood in the literal sense as 'having itself for its own in intimacy with itself." ${ }^{28}$ Admittedly, this explanation still leaves the issue unsettled. It does, however, at least clarify that Heidegger does not attribute moral or ethical dimensions to his thought. Thus, he remains closer to Husserl's phenomenology, but differs from Husserl in his attempt to outline the conditions that must pertain for philosophical thought to emerge. As Heidegger boldly asserts, for instance: “To ask 'How does it stand with Being?' means nothing less than to recapture, to repeat (reiterate), the

${ }^{27}$ Heidegger, History of the Concept of Time, 283.

${ }^{28}$ Ibid., 282. 
beginning of our historical-spiritual existence, in order to transform it into a new beginning. This is possible. ${ }^{\prime 29}$ This new beginning depends on one rediscovering the meaning of 'Being' and 'time' and a subsequent radical transformation of the temporal character of modern Dasein.

Heidegger acknowledges the importance of the past, (or history) but he dedicates far less time to analyzing its importance in comparison with the emphasis he places on the future, (with the exception of course of philosophical beginnings). Even so, he does contend that the past constitutes a significant part of Dasein's relation to others, to tradition, and to a general sense of history. Where history, "is that specific historizing of existent Dasein which comes to pass in time, so that the historizing which is 'past' in our Being-with-one-another, and which at the same time has been 'handed down to us' and is continuingly effective. ${ }^{\prime 30}$ However, Dasein can never be 'past' if past is understood as "now no longer either present-at-hand or ready-to-hand." ${ }^{31}$ Dasein is only anchored in its present and it is the present that contains the history of what has existed before Dasein.

Dasein's temporal character also includes a sense of future. And some of his most controversial and dangerous ideas, are evident in his answers to the question: "Is Dasein just something that 'has been' in the sense of 'having been there', or has it been as something futural which is making present - that is to say in the temporalizing of its temporality?" ${ }^{32}$ In other words, is Dasein made more aware, or does Dasein gain more of an appreciation, for its present, from its past or its

${ }^{29}$ Martin Heidegger, An Introduction to Metaphysics, trans. Ralph Manheim (New Haven: Yale University Press, Inc., 1987), 39.

${ }^{30}$ Heidegger, Being and Time, 379.

${ }^{31}$ Ibid., 380 .

${ }^{32}$ Ibid., 381. 
future? Heidegger does contend that Dasein has a sense of past. This sense of the past is more important than its awareness of the future. This is because Dasein finds itself primarily in the world, and the world is what gives Dasein its sense of the past, with its buildings and stories, its language, its customs, and so forth.

Heidegger's insight resonates with Thomas Mann who said: “A man lives not only his personal life, as an individual, but also, consciously or unconsciously, the life of his epoch and his contemporaries." Thus, the world "makes up an ontological attribute of Dasein.." ${ }^{\prime 3}$ Or, phrased differently, the world burdens Dasein with an additional sense of the past that is not entirely its own.

In sum, Dasein is primarily historical, but it is also surrounded by the secondary historical, or world-historical, that is comprised of entities Dasein encounters in the world. ${ }^{34}$ These entities, forming the second historical, in turn, generate for Dasein a stronger sense of past than of future. This stronger sense of the past hinders Dasein from attaining authentic temporality.

Heidegger proposes to remedy this by emphasizing the importance of Dasein's future. However, in doing so, Heidegger is able to steer away from speculations about the unknown and remain within Dasein's theoretical limitations, as an entity that questions Being. Consequently, Heidegger engages the future through the questioning of possibilities. For this questioning to be conducive to authentic temporality, and not veer off into pure speculation about the future, it must remain anchored in the present. Dasein is able to both engage with the future and remain connected to its present by facing 'now,' the future

${ }^{33}$ Heidegger, Being and Time, 381.

${ }^{34}$ Ibid., 
possibility of its death. As Heidegger writes, "If Dasein, by anticipation, lets death become powerful in itself, then, as free for death, Dasein understands itself in its own superior power, the power of its finite freedom. ${ }^{\prime \prime 3}$ Dasein is both aware of its finite nature and the future time that stretches from the present to its imminent death. Most importantly, it is able to relate to the future without the secondary historical that burdens Dasein in its relation to the past for the obvious reason that the future does not yet make its presence felt in the world the way the past does.

Thus, Dasein gains an intimacy with itself, an authenticity of sorts that allows it to project itself into the future and into history. As Heidegger writes:

Only an entity which, in its Being, is essentially futural so that it is free for its death can let itself be thrown back upon its factical 'there' by shattering itself against death - that is to say, only an entity which, as futural, is equiprimordially in the process of having-been, can, by handing down to itself the possibility it has inherited, take over its own thrownness and be in the moment of vision for 'its time.' Only authentic temporality which is at the same time finite, makes possible something like fate - that is to say, authentic historicality. ${ }^{36}$

Heidegger's argument amounts to no less than changing the very character of modern man, from one who he judges to be overly preoccupied with the past and oblivious to his future, to one who makes historical projection his primary preoccupation.

\footnotetext{
${ }^{35}$ Heidegger, Being and Time, 384.

${ }^{36}$ Ibid., 385.
} 
Being and Time, as well as Heidegger's earlier works, are silent about what this authentic historicality aimed at the future entails. Even Heidegger's own students made teasing remarks that Heidegger's lectures make them resolute, but uncertain about what they should be resolute towards. Politically speaking, since authentic historicity is communal, this resoluteness resonates with a call for a revolution, albeit one without an identifiable cause. Indeed, it is during revolutions that men are engaged primarily with the future and less concerned with the past. It is also during revolutionary times that, unfortunately, this preoccupation with the future generates and justifies present injustices as necessary for achieving a future end.

Though Heidegger's thought is primarily directed towards a radical transformation of some sort, there is also an understanding of time that rests at the very core of this transformation that can provide us with insight about immortality. Heidegger's argument in favor of a temporality, emphasizing futurity without explicitly invoking religion or metaphysics, represents a radically novel approach to time. Not only does it allow Dasein to appropriate time in an authentic manner, it also implies the unprecedented empowerment of Dasein; though Heidegger remains silent about the specifics of this empowerment. In other words, at its most authentic futurity, Dasein gains mastery over its time and it is subject to no other limitation than the one imposed by its own death.

The question, then, becomes 'What would this mean in the event that death itself is indefinitely postponed?' Authentic temporality is made possible by the certitude of death. If authentic time is Dasein's own to claim, based on its death, then to eliminate death is to eliminate Dasein's futurity and its presence in 
the world. This consequently eliminates its possibility towards authentic temporality. If, as Heidegger maintains, Dasein's authentic temporality is limited to Dasein's existence, then it is probable that rather than strive for an authentic future and suffer the anxiety of facing one's death that this authentic futurity requires, Dasein would struggle to achieve the only kind of temporality that is no longer bound by death. It would struggle for factual immortality.

To clarify, if Dasein can only have an authentic awareness of time when time is understood as Dasein's own, from now until the moment of its death, then rather than learning to face its death with the gravity Heidegger recommends, Dasein is more likely to preserve this time, especially because it is the only time that truly has meaning, or that truly exists. This insight resonates with the early Christian notion that death is necessary for Christ's sacrifice to have value, and for the futurity of the afterlife to have meaning. But it also differs radically from that of the early Christians' because Heidegger excludes the notion of eternity from it. For the early Christians, time took one of two forms: one earthly and one eternal. While alive in this world, human beings had the first, but they could not lay claim to the second.

In sum, what made it possible for the early Christians to survive persecution was not their resoluteness. Rather they were resolute because they believed that, when they died they would have access to an eternal time. By the same token, what allowed Socrates to remain calm before his death was his belief in a higher order of things of which he would become a part. In the absence of such beliefs, the unlimited extension of this earthly time gains an unprecedented value because it extends the only 'reality' that exists, granting Dasein the only time to which it can relate experientially; earthly time. 
Heidegger would consider this application of authentic temporality to be a gross misrepresentation and this is indeed correct. Authentic temporality does not make sense without the imminence of death. It is also the case that, once Dasein faces its death, the authentic temporality that would ensue would narrow time down to the mere experiences of Dasein.

Heidegger's phenomenology assumes that Dasein will have to face death. If it faces its own death properly, then it will experience an authentic relation to time. However, Heidegger could not have predicted that advancements in biotechnology could potentially make death itself a matter of choice. Rather, he works on the premise that death would be encountered sooner or later and that Dasein would benefit from learning to encounter its death earlier in the form of an idea, or in thought. This encounter was meant to root Dasein more firmly into this life. Thus, because authentic temporality cannot help Dasein to tap into a different relation to time, it renders existential time the only time for which Dasein can long. Under such circumstances Dasein has less incentive to face death and his own finitude.

\section{Immortals without time}

The way immortality is likely to be achieved, according to the most generous predictions, still does not eliminate death entirely; it merely postpones death for a later, or even a much later time. This postponement resembles an infinite time composed of an unending chain of 'nows,' or an infinite time of Das man or 'the they.' 
Das man, to recapitulate, is an entity that lacks sex and gender. It is translated as 'the they' to capture the gist of the expression: 'They say...' The 'they.' Das man is extensively discussed in Chapter 2 in conjunction with 'the other' and I will not revisit this discussion here. It is sufficient to say, that 'the they' suppress Dasein's possibility towards Being. Their very raison d'etre is antithetical to any authenticity Dasein may be able to experience. At the limit, 'the they' are capable of unleashing actual dictatorship. Yet, 'the they' is also each of us when we become the mouthpiece of beliefs we never questioned or reasoned through ourselves.

With regards to time, while authentic temporality can act as Dasein's time, and it is characterized by finitude, 'the they', by contrast, have eternity, understood as a series of 'now' moments. Heidegger writes:

The principal thesis of the ordinary way of interpreting time - namely, that time is 'infinite' - makes manifest most impressively the way in which world-time and accordingly temporality in general have been leveled off and covered up by such an interpretation. It is held that time presents itself proximally as an uninterrupted sequence of 'nows.'...Hence time is endless 'on both sides.'...In this way of thinking time through to the end, one must always think more time; from this one infers that time is infinite. ${ }^{37}$

'The they' act as a dark reminder that the world existed before Dasein's authentic temporality, and it will continue to exist even after Dasein has died. For, "Time goes on, just as indeed it already 'was' when a 'man came into life."'38

${ }^{37}$ Heidegger, Being and Time, 424.

${ }^{38}$ Ibid. 
Furthermore, because the time of 'the they' continues to unfold, it also has the potential to absorb Dasein's time into itself and make it immortal, provided Dasein is willing to surrender the conscience of his mortality. Time for 'the they' is a time "leveled off and which belongs to everyone - and that means, to nobody. ${ }^{\prime \prime 3}$ Phrased differently, the time of 'the they' grants immortality to all alike in the form of eternal continuity. But 'the they' cannot grant authentic temporality.

There are strong similarities between the time of 'the they' and the biomedical promise of immortality on this side of the grave. Proponents for immortality do not believe that man will simply be immortal in the sense of "whole" (or complete) the way an immortal God would be. On the contrary, they argue that, for man to be immortal in the future, he will need to forge a permanent symbiotic relationship with biomedical technology. Biomedical technology will thus eliminate the need for human adaptation to the environment, and it will instead force the environment to accommodate to our needs. Aside from the dangers this entails, in the event that it proves realistic, and that men are indeed able to fend off death, then they would continuously expand their reach into the future. This is to say that they would grasp for more and more time in an attempt to master it ad infinitum.

In sum, just like the time of 'the they', biomedical technology also offers an extension of the 'now' moments that Dasein's time would contain from the present to its death, but it is unable to offer an authentic temporality. Biomedical immortality merely gives the infinite time 'the they' have a practical quality. This also means that, while biomedical technology might ensure physical

${ }^{39}$ Heidegger, Being and Time, 425. 
immortality, it would also make it easier for 'the they' to evade direct engagement with the possibility of death and to discuss it only through the intermediary of new life expanding technologies.

From the perspective of authentic temporality, as illustrated by Heidegger, this would be akin to a nightmare. But does not the rationale of authentic temporality also encourage, at least in part, the application of biomedical technology to expanding life? I believe it does, especially through its emphasis on the future. Authentic temporality advocates an embrace of the future that can justify, if not physical immortality per se, at least the possibility of a new beginning rooted in the ability to reclaim time from the 'they.'

It is true that Heidegger argues one can only reclaim authentic time from 'the they' by facing one's own death. But this is merely at the level of thought. In actuality, since the possibility of death will always remain present irrespective of advancements in biomedical technology, and since one can always be killed, the ability to claim control over Dasein's time would even be aided by technology. Dasein's ability to master time would, of course, be inauthentic because it would no longer be predicated on Dasein's genuine awareness of its own death. Nevertheless, it would also preserve the future orientation of personalized time to sufficiently mimic authentic temporality and thus make physical immortality desirable.

\section{Concluding remarks}


The following remarks will build on my analysis of temporality, but it will be more speculative in nature. This is inevitable given that, to date, physical immortality remains beyond our reach. Nevertheless, though immortality has not yet materialized, Heidegger's thought can give us a sense of how human beings able to fend of death for longer would live, and especially how they would relate to time.

Here, I rely on Heidegger's notion of temporality and his views on technology. Authentic temporality and its emphasis on the future promises to shelter Dasein from the oppression of stultifying ancient beliefs and of liberating Dasein towards a new beginning. It also promises to give back to Dasein an intimate relation, not just with time in general, but with its own time. This, in effect, is another way of saying that it allows Dasein to control the manner in which it will live and the choices it will make.

These are alluring promises to any mortal, even though they also imply a revolutionary character in the form of historical action, or thought, or both. However, as I show in this chapter, authentic temporality does not shelter Dasein from the dangers Heidegger articulates about modern technology. Even more striking, in the case of biomedical technology that promises physical immortality, authentic temporality even provokes this kind of aggressive technological intervention. In other words, while Heidegger demonstrates a commitment to prudent reflection in his approach to Being as clearance later in life, he also expresses an aggressive and controlling impulse with regards to the future in his earlier years. This aggressive impulse could be used to justify efforts to bring about immortality on this side of the grave. 
The most dreadful scenarios involving physical immortality that Heideggerian insight can help us identify are not only valuable from a philosophical perspective. Rather, his insights are valuable for outlining what life would be like for an immortal human being. Biomedical technology promises a kind of physical immortality that still allows for the possibility of death, even though it renders it less probable. This means that men would still be able to think about their finitude, but, when doing so, they would find progressively more resistance from the world around them. Consequently, men would live longer, but their lives would be lived in absolute terror of death. The mood of horror and boredom that Heidegger argues typifies the Cold War era, under constant threat of nuclear war, would also apply to a world of immortal beings.

A world where men could continuously fend of death, while aided and abetted by biomedical technology, could be a world where the fear of death is ubiquitous, but where people do not discuss this fear because they would be preoccupied solely with living longer. If immortality were to materialize, it would characterize a world that may preserve, just like Heidegger's thought did, the music of metaphysics that long ago cleared the path towards Being. But its relation to time would eternally testify to the moment when it all fell silent. 


\section{Conclusion}

Man has searched to find his place in the universe either through politics, through his ability to reason, through the idea of a soul, through romantic love, or even anthropologically through laughter. ${ }^{1}$ The means he has used to understand his place in the cosmos have consequently determined how he has made sense of his impending death. This trend continues to this day. Interestingly, however, Heidegger has reversed the order of this pursuit. According to Heidegger, facing the possibility of his death causes man to derive a sense of urgency about discovering his place in the larger whole.

If one were to be generous towards Heidegger, one could say that the experiential foundation on which Heidegger builds his thought, though not the actual cosmology, resonates with Greek myth and drama. The heroes of old, after all, were painfully concerned about the limits death imposed on them, and they had an acute awareness that Hades would devour their beauty, their memory, their reason, and finally even their language. And, this awareness is primarily what prompts the Ancient Greek heroes to live with a sense of urgency. This sense of urgency typifies Greek heroes to such an extent that we can no more imagine a lethargic Greek hero any more than we can imagine a sense of urgency among thinkers like Kant. The kind of approach to life Heidegger proposes has powerful dramatic elements meant to resurrect in men a more intense appreciation for life. These dramatic elements stem undoubtedly from

${ }^{1}$ Johan Huizinga, Homo Ludens: a study of the play element in culture (Boston: The Beacon Press, 1955), 6. 
Nietzsche's influence. But because Heidegger places such importance on death, they no longer retain the playful atmosphere with which Nietzsche re-introduced them into modernity.

However, regardless of the larger influences on Heidegger, the fact remains that the Greek cosmology, from which the Ancient heroic call to action derived, is absent from Heidegger's thought. Consequently, man's knowledge of his immanent death becomes itself uprooted from any larger meaning or order. For this reason, dying is devoid of either Socratic calmness, or the fear of Hell or the longing for Paradise. Heidegger would contend, that it is from exactly this void that man can once again derive a sense of purpose and urgency. This is Heidegger's promise to modern man. For this reason, one would be mistaken to label Heidegger as a backward-looking romantic. Indeed his engagement with Being, even in its unfinished form in Being and Time, is not meant to imitate the Ancient Weltanschauung, but more so to act as a transition towards radically new, and therefore uncharted, territory.

The absence of a higher system of integrated knowledge in his work, combined with his promise that a sense of meaning for our lives and deaths is nevertheless possible, make Heidegger particularly alluring to modern thinkers. This allurement, however, comes with dangerous political implications. Here, I have examined some of those dangers as they relate to dying and death, focusing particularly on modern developments in biotechnology. This approach helps us see, not only the contradictions in Heidegger's own thought, but, more importantly, that the multifarious expressions of freedom in Heidegger's work are difficult to accommodate within our liberal tradition. Though Heidegger was critical of the German Idealist tradition, from which many of these radical 
freedoms are derived, his way of addressing them in his work is still incompatible with liberal principles. Therefore, despite Derrida's belief that Heidegger could provide us with the best discourse on dying and death, we ought to remain skeptical about relying on Heideggerian insight to enrich our current bioethical debates.

The fascination with freedom, unleashed by the French Revolution and the subsequent substitution of duty for rights, has come to be synonymous in our time with the good life and justice itself. It is an important tradition, one that has proven itself rather resilient over the centuries. Yet, its foundation has always been based on a harsh Hobbesian insight that derived the right to life from the fact that we are all mortal and can all be killed. This right to life offered man a guarantee that he would not be killed unless, of course, he threatened the state itself or the state required him to defend it. Even as subsequent rights were added to this tradition, rights that occasionally trivialized and even obscured this tradition (such as 'animal rights'), this foundation continued to hold.

The one right this tradition cannot withstand is the right to die. This 'new' right stems from a different type of thought. Its roots can be traced back to Schopenhauer's nihilism, but its actual appeal rests with Nietzsche's subsequent attempt to overcome these nihilistic roots. In the process, the right to die became associated with an embrace of a life that knows no boundaries and risks romantically embracing death itself. This limitless quality is also incorporated in Heidegger's thought and present in Being and Time.

Despite some of the limitless possibilities Heidegger unleashes, one can still distinguish some elements of prudence in his thought. This can be seen in the way he roots Dasein in a world of care. While in thought, man is encouraged 
by Heidegger to contemplate his own death, this has no relation to the actual act of committing suicide. Not only is Heidegger openly opposed to suicide, but the very translation of Dasein as 'Being-here' makes this possibility nonsensical. This has not prevented at least one psychiatrist, James Werth from using his patient's suicidal thoughts to persuade her not to commit this act. This practice is irresponsible because it denotes a fundamental lack of understanding about Heidegger's philosophical insight. In short, Heidegger's insights on death do not easily lend themselves to practical applications and if they are used as such they can be fatal.

Dasein's openness towards limitless possibilities also includes the possibility for authentic relations with others. These relations are not political in the Aristotelian sense. Rather, the authentic social relations Heidegger prefers grant man an organic sense of belonging. This sense of belonging allows men to relate to others based on empathy and to attain a sense of shared historical destiny. It also generates homogeneity of views and sentiments under a common understanding of the world that risks obliterating differences between individuals and between groups. It is also a homogenous understanding of politics in which laws are rooted in a sense of common empathy with others. In such a world, the difference between ethics, as subjective guidelines, and laws, as objective and universal decrees, become merged into a shared destiny for all. This approach to politics has proven disastrous in the past during Nazi rule in Germany and Heidegger himself no longer discussed it after the War.

Interestingly, modern arguments for euthanasia also involve sentiments of empathy to justify state and medical intervention to terminate not only the suffering of a dying person, but his or her very life. This approach is not fascistic 
per see, but it does point to a similar danger of eliminating the difference between law and ethics. In short, they share in the belief that empathy is a sufficient sentiment on which to base an entire standard for judging when a life could or should end.

Indeed, this organic unity to which Heidegger was attracted both in thought, and in his actual support of the Nazis, is also the reason why he remains blinded to a great resource for questioning technology. His work on technology has unleashed tremendous debate and continues to provide the harshest representation of the danger humanity faces in its pursuit of modern technology. The danger of obliterating its sense of being is that of becoming matter itself, or standing reserves. Life support technology is one of the closest approximations of this condition to date. It is a contained setting in which machines are increasingly relied upon to dictate the transition from life into death. Heidegger argues that art will challenge technology when the sense of danger will grow. Indeed, in the Intensive Care Units of our modern hospitals, the danger is ubiquitous, but art is not the force that comes to aid the families and doctors making those decisions. Politics is. Indeed, it may be that, if answers to questions concerning technology will be found at all, they will be found in politics, not in art. And thus, politics will be the more solid foundation on which to question technology.

And, as with most modern thinkers, prudence is the exception rather than the norm for Heidegger as well. Nothing reveals Heidegger's imprudent tendencies clearer than his approach to time and his emphasis on the future. The kind of contemplation of Being he advocates especially in his later writings, is completely absent in his approach to time. In Being and Time, man must control 
time. This approach to the future is of tremendous importance for understanding arguments justifying immortality in the future. Heidegger himself would object to this use because physical immortality hallows-out the meaning of his insights from Being and Time. His entire work, after all, is predicated on the imminence of death. On another level, the emphasis Heidegger places on authentic temporality opens the possibility of making time one's own and thereby bound to nothing else. Consequently, from now until one's death, time becomes one's very own, to do with it as one pleases. And if he wishes to expand this time indefinitely, Heidegger offers no limitation.

This is not to suggest that Heidegger would approve of an argument for immortality. On the contrary, according to his work, this would amount to an inauthentic existence. Yet, faced with the actual possibility of immortality, Dasein might actually opt to pursue it, however inauthentic such a pursuit might be. Simply put, Heidegger's approach to time remains loyal to his maxim: 'higher than actuality stands possibility' and possibility is limitless.

Ironically, in these limitless possibilities rests Heidegger's great contribution. His concepts, and even his overall phenomenology, do pose great dangers to us liberals. But his greatest contribution to thought was arguably never any of those. Indeed, Heidegger's great contribution was to ask (not to answer) about Being at a time when logic and science considered the matter closed. These questions brought Heidegger to the beginning of early thought and it is with an anecdote from this early time on which I close. It was said that Solon, in his travels, met Croesus, King of Lydia. Croesus believed himself to be the happiest man alive and demanded Solon agree with him. Solon answered: 'Count no man happy until he is dead.' And, his answer continues to be relevant. 
It captures the fact that the search for justice in dying and death is in reality a search for the good life. 


\section{Bibliography}

Abrams, M. Howard. Natural Supernaturalism: Tradition and Revolution in Romantic Literature. New York: W.W. Norton \& Company, 1971.

Aliverdinia, Akbar. “Women's Fatalistic Suicide in Iran A Partial Test of

Durkheim in an Islamic Republic." Violence Against Women 15 (2009): 307320.

Amarasekara, Kumar and Mirko Bagaric. "The Vacuousness of Rights in the Euthanasia Debate." The International Journal of Human Rights 6 (2007): 1944.

Arendt, Hannah. The Origins of Totalitarianism. New York: Library of Congress, 1966.

Aries, Philippe. Western Attitudes toward Death. Baltimore: John Hopkins UP, 1974.

Augustine of Hippo, Saint. Confessions. Translated by R.S. Pine-Coffin. London: Penguin Books, 1961.

Barrett, William. The Illusion of Technique. New York: Anchor Books, 1979.

Battin, P. Margaret. The Least Worst Death: Essays in Bioethics on the End of Life. Oxford: Oxford UP, 1974.

Benecke, Mark. The Dream of Eternal Life: Biomedicine, Aging, and Immortality. Translated by Richard Rubenstein. New York: Columbia UP, 2002.

"Beowulf." In The Longman Anthology of British Literature. Vol.1, Edited by Christopher Baswell and Anne Howland Schotter. New York: AddisonWesley Educational Publishers, Inc., 1999. 
Bova, Ben. Immortality: How the Science is Extending Your Life Span - And

Changing the World. New York: Avon Book, 1998.

Breck, John. The Sacred Gift of Life: Orthodox Christianity and Bioethics. New York:

St. Vladimir's Seminary Press, 2000.

Chalke, H. D. "The Impact of Tuberculosis on History, Literature and Art."

Medical History 6 (1962): 301-318.

Dahlstrom, Daniel. Heidegger's Concept of Truth. Cambridge: Cambridge UP, 2001.

De Grey, Aubrey. "The War on Aging." In The Scientific Conquest of Death: Essays on Infinite Life Spans, Buenos Aires: The Immortality Institute, 2004.

Derrida, Jacques. Aporia. Stanford: Stanford UP, 1983.

Dormandy, Thomas. The White death: A history of Tuberculosis. New York: New York UP, 1999.

Durkheim, Emile. Suicide: A Study in Sociology. Translated by John A. Spauling and George Simpson. Glencoe: The Free Press, 1951.

Fukuyama, Francis. Our Posthuman Future: Consequences of the Biotechnology

Revolution. New York: Farrar, Straus and Giroux, 2002.

Gallagher-Thomson, Dolores, and Nancy J. Osgood. “Suicide in Later Life."

Behavior Therapy 28 (1997): 23-41.

Gandey, Allison. "New Brain Death Guidelines Issued." Medscape Medical News.

Accessed June 10, 2010. http: / / www.medscape.com/viewarticle/723342

Grant, George. Technology and Justice. Concord: House of Anansi Press, 1986.

Habermas, Jurgen. The Philosophical Discourse of Modernity: Twelve Lectures.

Translated by Frederick Lawrence. Massachusetts: The MIT Press, 1987.

Hawke, Chris. "Report: State Tried Schiavo Grab." CBS News. Accessed March 
26, 2005.

http://www.cbsnews.com/stories/2005/03/26/national/main683300.shtml

Heidegger, Martin. Being and Time. Translated by John Macquarrie and Edward Robinson. Oxford: Blackwell, 1962.

------ "The Self-Assertion of the German Universities." Translated by Dagobert

D. Runes. In German Existentialism, New York: Wisdom Library, 1965.

------ "German Students." Freiburger Studentenzeigung. In German Existentialism

Nov. $3^{\text {rd }}, 1933$. Translated by Dagobert D. Runes. New York: Wisdom

Library, 1965.

------ Poetry, Language and Thought. Translated by Albert Hofstadter. New York: Perennial Classics, 1971.

----- “Letter on Humanism." In Martin Heidegger: Basic Writings, Translated by David Farrell Krell. San Francisco: HarperCollins, 1993.

------ "The Question Concerning Technology." In Basic Writings. Edited and translated by David Farrell Krell. San Francisco: Harper Collins, 1933.

------ History of the Concept of Time. Translated by Theodore Kisiel. Bloomington: Indiana UP, 1985

----- Hegel's Phenomenology of Spirit. Translated by Parvis Emad and Kenneth Maly. Indiana: Indiana UP, 1988.

------ On Time and Being. Translated by Joan Stambough. New York: Harper and Row, 1972.

------ An Introduction to Metaphysics. Translated by Ralph Manheim. New Haven: Yale UP, 1987.

------ The Phenomenology of Religious Life. Translated by Matthias Fritsch and Jennifer Anna. Bloomington: Indiana UP, 2004. 
------ The Essence of Human Freedom. Translated by Ted Sadler. New York: Continuum, 2005.

------ Schelling's Treatise on the Essence of Human Freedom. Translated by Joan Stambaugh. Athens, Ohio: Ohio UP, 1985.

------ Nietzsche. Vol. 1 \& 2, Translated by David Farrell Krell. San Francisco: Harper Collins, 1991.

------- Parmenides. Translated by André Schuwer and Ricard Rojcexicz.

Bloomington: Indiana University Press, 1992.

Hobbes, Thomas. The Leviathan. London: Penguin Books, 1968.

Huizinga, Johan. The Autumn of the Middle Ages. Translated by Rodney J. Payton and Ulrich Mammitzsch. Chicago: University of Chicago Press, 1996.

----- Homo Ludens: a study of the play element in culture. Boston: The Beacon Press, 1955.

Humphry, Derek. Final Exit: The practicalities of self-deliverance and assisted suicide of the dying. New York: Bantam Doubleday Dell., 1991.

Jonas, Hans. "The Right to Die." The Hastings Center Report. Vol. 8:4 (1978): 31-36.

Jonsen, Albert R. The New Medicine and the Old Ethics. USA: Harvard UP, 1990.

Kant, Immanuel. Fundamental Principles of the Metaphysics of Morals. In Basic Writings of Kant. Edited by Allen Wood, 143-223. New York: Modern Library, 2001.

------ The Critique of Judgment. In The Norton Anthology of Theory and Criticism. Edited by William E. Cain et al. Translated by Werner S. Pluhar. New York: W.W. Norton \& Company, 2001.

Kass, R. Leon. Life Liberty and the Defense of Dignity: the Challenge for Bioethics. San Francisco: Encounter Books, 2002. 
Kurzweil, Ray and Terry Grossman. Fantastic Voyage: Live Long Enough to Live Forever. New York: Rodale, 2004.

------ Transcend: Nine steps to living well forever. New York: Rodale, 2009.

Lavi, J. Shai. The Modern Art of Dying: A history of euthanasia in the United States. Princeton: Princeton UP, 2005.

Locke, John. The Second Treatise of Government. New York: Cambridge UP, 1993.

Lotz, Christian. "Existential idealism? Fichte and Heidegger." Epoché, 12(2007): 109-135.

Luce, John, and Ann Alpers. "Legal Aspects of Withholding and Withdrawing Life Support from Critically Ill Patients in the United States and Providing Palliative Care to Them." Respiratory and Critical Care Medicine 162 (2000): 2029-2023.

Macquarrie, John. Heidegger and Christianity: The Hensley Henson Lectures 1993-94.

New York: Continuum, 1994.

McCormick, Richard A. “To Save or Let Die: the Dilemma of Modern Medicine." In Contemporary Issues in Bioethics. Edited by Tom L. Beauchamp and LeRoy W. Belmont. California: Wadsworth, Inc., 1978.

Minois, George. History of Suicide: Voluntary Death in Western Culture. Translated by Lydia G. Cochrane, Baltimore: John Hopkins UP, 1999.

Nietzsche, Friedrich. Thus Spoke Zarathurstra. Translated by R.J. Hollingdale. London: Penguin Books, 1969.

------ The Gay Science. Translated by Walter Kaufmann. New York: Vintage Books, 1974. 
------ Beyond Good and Evil. Translated by Walter Kaufmann. New York: Vintage Books, 1989.

------ The Will to Power. Translated by Walter Kaufmann and R.J. Hollingdale. New York: Vintage Books, 1967.

Northcott, Herbret C. and Donna M. Wilson. Dying and Death in Canada, second Edition. Peterborough: Broadview Press, 2008

Paris, John J. and Michel P. Moreland. "A Catholic Perspective on PhysicianAssisted Suicide." In Physician Assisted Suicide: Expanding the Debate. Edited by Margaret P. Battin, Rosamound Rhodes and Antia Silvers. New York: Routledge, 1998.

Pieper, Joseph. An Anthology. San Francisco: Ignatius, 1989.

Plato. The Republic. Translated by Allen Bloom. New York: Basic Books, 1991. Pontin, Jason. "Is Defeating Aging only a dream." In Technological Review (July 11, 2006). Accessed July 1, 2010. http://www.technologyreview.com/sens

Rilke, Maria Rainer. The Notebooks of Malte Laurids Brigge. Translated by M. D.

Herter Norton. New York: W.W. Norton \& Company, 1964.

Ruin, Hans. "The Destiny of Freedom: in Heidegger." Continental Philosophy Review 41 (2008): 277-299.

Safranski, Rudiger. Martin Heidegger: Between Good and Evil. Cambridge, MA: Harvard UP, 1998.

Somerville, Margaret. The Ethical Canary: Science, Society and the Human Spirit. Toronto: Viking/Penguin Canada, 2000.

------ “Living with Dignity when Dying." Presented at The Quebec Public Consultation on "Dying with Dignity, (Quebec), (July 13 2011). 
Schopenhauer, Arthur. The World as Will and Representation. Translated by E. F. J. Payne. New York: Dover, 1969.

----- "On Suicide." In Essays and Aphorisms. London: Penguin Books, 1970.

Smith, J. Wesley. Culture of Death: The Assault on Medical Ethics in America. San Francisco: Encounter Books, 2000.

Szasz, Thomas. Fatal Freedom: the ethics and politics of suicide. Wesport: Praeger, 1999.

Tolstoy, Leo. The Death of Ivan Ilych and Other Stories. Translated by Aylmer Maude and J. D. Duff. New York: A Signet Classic, 1960.

Verhey, Allen. “A Protestant Perspective on Ending Life: Faithfulness in the Face of Death." In Physician Assisted Suicide: Expanding the Debate. Edited by Margaret P. Battin, Rosamound Rhodes, and Antia Silvers. New York: Routledge, 1998.

Walton, Douglas N. Ethics of Withdrawal of Life-Support: Case Studies on Decision Making in Intensive Care. London, UK: Greenwood, 1983.

Werth, L. James. “Using Rational Suicide as Intervention to Prevent Irrational Suicide." Crisis 19(1998): 185-192.

Whitehead, A. N. Science and the Modern World. New York: Mentor Books, 1949.

Wijdicks, Eelco F.M., et. Al. "Evidence-based Guideline Update: Determining Brain Death in Adults." Neurology 74 (2010): 1911-1918.

Wilson, Jerry. Death by Decision: the Medical, Moral and Legal Dilemmas of Euthanasia. Philadelphia: Westminster, 1975.

Williams, Glanville. "'Mercy-killing' Legislation - A rejoinder." In Contemporary Issues in Bioethics. Edited by Tom L. Beauchamp and LeRoy Walters. California: Wadsworth, 1978. 
Zimmerman, Michael E. Heideger's Confrontation with Modernity: Theology, Politics and Art. Indiana: Indiana UP, 1990. 